\title{
REVIEW OF THE ASIATIC FRESHWATER PUFFERS OF THE GENUS TETRAODON LINNAEUS, 1758 (PISCES, TETRAODONTIFORMES, TETRAODONTIDAE)
}

\author{
by
}

\author{
W. J. DEKKERS \\ Institute of Taxonomic Zoology, University of Amsterdam, The Netherlands
}

\section{CONTENTS}

\begin{abstract}
. . . . . . . . . . . . . . . . . . . 88
Introduction . . . . . . . . . . . . . . . . . 88

Methods . . . . . . . . . . . . . . . . . . . . . . . 89

Abbreviations . . . . . . . . . . . . . . . . . . . . 91

Acknowledgements . . . . . . . . . . . . . . . . . . 91

Taxonomic part . . . . . . . . . . . . . . . . . . . 92

Genus Tetraodon . . . . . . . . . . . . . . . . . . . . . 92

Key to the species-groups, species and subspecies . . . . . . . . . . 92

cutcutia-group . . . . . . . . . . . . . . . . . . . . . . 93

Tetraodon cutcutia Hamilton, 1822 . . . . . . . . . . . . . . 95

Tetraodon lorteti Tirant, 1885 . . . . . . . . . . . . . . . . . . . . . 97

Tetraodon travancorius Hora \& Nair, 1941 . . . . . . . . . . . 101

leiurus-group . . . . . . . . . . . . . . . . . . . . 102

Tetraodon palembangensis Bleeker, 1852 . . . . . . . . . . . 104

Tetraodon leiurus sensu lato . . . . . . . . . . . . . . . . 107

Tetraodon leiurus Bleeker, 1851 . . . . . . . . . . . . . . . 108

Tetraodon fangi Pellegrin \& Chevey, 1940 . . . . . . . . . . . 112

erythrotaenia-group . . . . . . . . . . . . . . . . . . . . 114

Tetraodon erythrotaenia Bleeker, 1853 . . . . . . . . . . . . . 115

fluviatilis-group . . . . . . . . . . . . . . . . . . . . . 117

Tetraodon fluviatilis sensu lato . . . . . . . . . . . . . . . 120

Tetraodon kretamensis Inger, 1953 . . . . . . . . . . . . . . 121

Tetraodon nigroviridis Marion de Procé, 1822 . . . . . . . . . . 123

Tetraodon fluviatilis fluviatilis Hamilton, 1822 . . . . . . . . . . 127

Tetraodon fluviatilis sabahensis nov. subsp. . . . . . . . . . . . 130

Tetraodon steindachneri nom. nov. . . . . . . . . . . . . . . 132

waandersii-group . . . . . . . . . . . . . . . . . . . . . 134

Tetraodon waandersii Bleeker, 1853 . . . . . . . . . . . . . 134

References . . . . . . . . . . . . . . . . . 136

Index to the taxonomic part . . . . . . . . . . . . . . . . . 141
\end{abstract}




\section{ABSTRACT}

The present review of the Asiatic freshwater puffers of the genus Tetraodon was thought necessary because the only preceding review (Le Danois, 1959) disregards some major taxonomic rules and methods. The material studied originates from existing museum collections and comprises type material of most of the species concerned. The concept of the genus Tetraodon is adapted after FraserBrunner (1943) with exclusion of $T$. (Chelonodon) patoca, which is not considered.

One new subspecies ( $T$. fluviatilis sabahensis) is described, one new name ( $T$. steindachneri) is introduced, two neotypes ( $T$. fluviatilis fluviatilis Hamilton, 1822 and $T$. nigroviridis Marion de Procé, 1822) are designated, and one lectotype ( $T$. lorteti Tirant, 1885) is selected. For the sake of convenience in discussing the taxonomic value of the characters used the species are grouped in five species-groups:

cutcutia-group ( $T$. cutcutia Hamilton, 1822, $T$. lorteti Tirant, 1885, T. travancorius Hora \& Nair, 1941)

leiurus-group (T. palembangensis Bleeker, 1852, $T$. leiurus Bleeker, 1851, T. fangi Pellegrin \& Chevey, 1940)

erythrotaenia-group (T. erythrotaenia Bleeker, 1853)

fluviatilis-group (T. kretamensis Inger, 1953,

$T$. nigroviridis Marion de Procé, 1822,

T. fluviatilis fluviatilis Hamilton, 1822,

$T$. fluviatilis sabahensis nov. subsp.,

$T$. steindachneri nom. nov.)

waandersii-group ( $T$. waandersii Bleeker, 1853).

\section{INTRODUCTION}

Although the taxonomy of the Asiatic freshwater puffers has been studied quite intensively from the beginning of the 19th century, much systematic confusion is left to be cleared. Partly this is due to the peculiarities of the group, partly to the peculiarities of the scientists studying it.

Hamilton, the first major contributor to our knowledge of the Asiatic Tetraodon species, based his study (1822) on fishes from the Ganges river system. He made poor descriptions and did not leave collections. As he points out himself, the illustrations therefore are of uttermost importance. Unfortunately, the illustrations of three out of his six new Tetraodon species were lost at the time of printing, of which only one was refound. The problems connected with this are discussed by Gudger (1924), Hora (1929), and others.

The second major contributor, Bleeker, in his publications on the genus (1849-1868) is mainly concerned with Indonesian fishes. He had no means to compare his material with the species described by Hamilton from Bengal. He did leave a huge fish collection, but most of his type ma- terial is not readily recognizable because of scanty labelling and of not being kept apart. The problems evolving from this are treated by $\mathrm{De}$ Beaufort (1964), Boeseman (1972), Hubrecht (1879), Rofen (MS.), and Whitehead et al. (1966).

Amongst the 19th century French ichthyologists, most work on Tetraodon was carried out by Bibron. This, however, was never published as such; it still rests as a manuscript in the Muséum National d'Histoire Naturelle, Paris. Much of the information in it, however, was subsequently published by Duméril (1855), including numerous new generic names which have not stood the test of time well at all.

Other 19th century workers on the group, like Cantor, De Castelnau, Marion de Procé and Tirant, present comparable complications. De Castelnau only left a sketchbook concerning Tetraodon, the material of Marion de Procé was destroyed for the greater part during a revolt, and neither Cantor nor Tirant left illustrations of their new Tetraodon species. Like most 19th century scientists they had to rely very much on the descriptions of their colleagues from abroad, as they had little access to material from colonies other than their homeland's.

In our century a useful compilation of knowledge on Indonesian species was given by De Beaufort (1962). Some years before, in 1959, Le Danois had published the only attempt at a real review on the specific level. Her extensive monograph on what she calls the "Orbiculates" turned out, however, to make matters even more com. plicated. She did a bad service to science by neglecting other than material in Paris, by neglecting the internationally approved type concept, by neglecting illustrations accompanying original descriptions, by exhuming forgotten names of unrecognizable nominal species, and by raising myological characters to the highest ranks of taxonomically important characteristics. Her views on osteology were conclusively refuted by Tyler (1963). One quotation of him (: 205) probably will do: "the line drawings of the skulls are inaccurate, for they show many more bones than actually exist."

The taxonomic confusion due to the peculiarities of the fishes themselves originates in their polymorphism. Besides the known variability connected with geographical distribution, aquarium studies by Benl (1957 a \& b), Benl \& Chlupaty (1957), and Klausewitz (1957 a \& b), and field studies by Sontirat et al. (1971) have shown con- 
siderable changes in colour and shape depending on age, sex, mood, habitat type, and lighting. Striking sexual dimorphism was shown in $T$. lorteti and perhaps more sexual dimorphism will be found in the group as the phenomenon is not rare in the Tetraodontiformes. It was shown e.g. in another family of the group, the Ostraciontidae, in the species Ostracion meleagris Shaw, 1796, and $O$. solorensis (Bleeker, 1853) by FraserBrunner (1940). Variations with age could be even stronger in nature than in aquarium life because most species are recorded from fresh and brackish waters and some even from marine waters. This implies that one must reckon with variation due to ecological and migratorial circumstances. The latter proposition could not be verificated in the present paper; this would need far more material from exact localities. Variations with mood include the inflating and deflating of the belly region. Body depth and body width therefore taxonomically are almost useless. The apparent size and distribution of the spines also vary with mood, that is to say, the spines can be retracted to a great extent under the skin, often in specialized dermal pits or under dermal papillae. Records of early authors, considering size and distribution of the spines a major character, are not reliable in this respect.

On the other hand, some characters proved to be so constant throughout the genus that they could not be used either. This in the first place concerns form and position of the fins, mouth width, and eye diameter.

After eliminating the variable characters overlapping too much between species and the constant characters of the genus, only the following characters proved to be useful:

- structure of the nasal organ

- relative snout length

- relative head length

- form of the interorbital region

- position of the mouth

- colour pattern

- fin ray counts (although variable within one species).

Colour pattern is incorporated in the diagnostic characters only when it showed remarkably constant differences, and when no individual colour pattern contradicted the proposed discrimination. What happens when colour pattern is not incorporated is shown by Le Danois, who in doing so reduced the number of Orbiculate species from 320 to 50 . Without splitting according to colour pattern, the group named in this paper fluviatilis- group would have to be regarded as a single species with fin ray counts: D 10-16; A 10-14; $P 18-24$. Although variations in fin ray counts like this might occur in a single archipelagic species - certainly when one regards it as a superspecies - I consider it more opportune to distinguish species and subspecies as long as the available material prohibits a more advanced taxonomic approach.

It must be said that the scope of the present study does not go beyond classical taxonomy: the classical taxonomic problems inherited from the 19th century must be cleared before starting ecological, population dynamical, or experimental research.

The present study is based on comparison of existing museum series and data recorded in publications. Some authors intended such comparisons, but local or temporary circumstances prevented actual action. Bleeker (1865a: 68) for instance, after 16 years of contemplating, declared his $T$. potamophilus a junior synonym of Crayracion fluviatilis (Hamilton, 1822), not because he was convinced of it being so, but because he did not have material for comparisons. In the present paper both nominal species are separated again (as $T$. fluviatilis and $T$. nigroviridis). Many type specimens are compared for the first time with other type specimens and neotypes are designated when necessary to prevent future confusion.

Besides the approach mentioned above, zoogeographical arguments and aquarium data were used - although with caution. While Tetraodon species are by no means primary freshwater fishes, they follow to some extent the zoogeographical distribution patterns of the latter as discussed by De Beaufort $(1926,1951)$ and reviewed by Inger \& Chin (1962). The Wallace Line, for instance, does divide Tetraodon species: $T$. erythrotaenia is the only one living east of it. Another remarkable zoogeographical hypothesis can be demonstrated in Tetraodon species, viz. the strong variability of the six species living in Borneo. This variability supports the thesis of De Beaufort and others, assuming that at least two separate immigration flows occurred in the island and that both flows were mixed only partially, due to the barriers formed by the prominent mountain ridges.

\section{METHODS}

For the various aspects of the species treated, 
the following methods and ways of representation were used:

Synonyms and references. - References to scientific publications aim at completeness; aquarium publications are referred to only when important for taxonomic purposes. "Figure" always represents lateral depictions or photographs of living specimens, unless stated otherwise between brackets. The word "listed" indicates that no description was given. Localities of recorded material were mostly transcribed in a more recent geographical equivalent when appropriate. If a recorded locality is based on material reported on earlier by the same or another author, it is not listed. If all localities and material were listed earlier, this is indicated by "no additional material"; if there is no indication that material other than living specimens were recorded this is indicated by "no material". If it is known or suspected with great probability in which museum collection the material recorded is or was present,
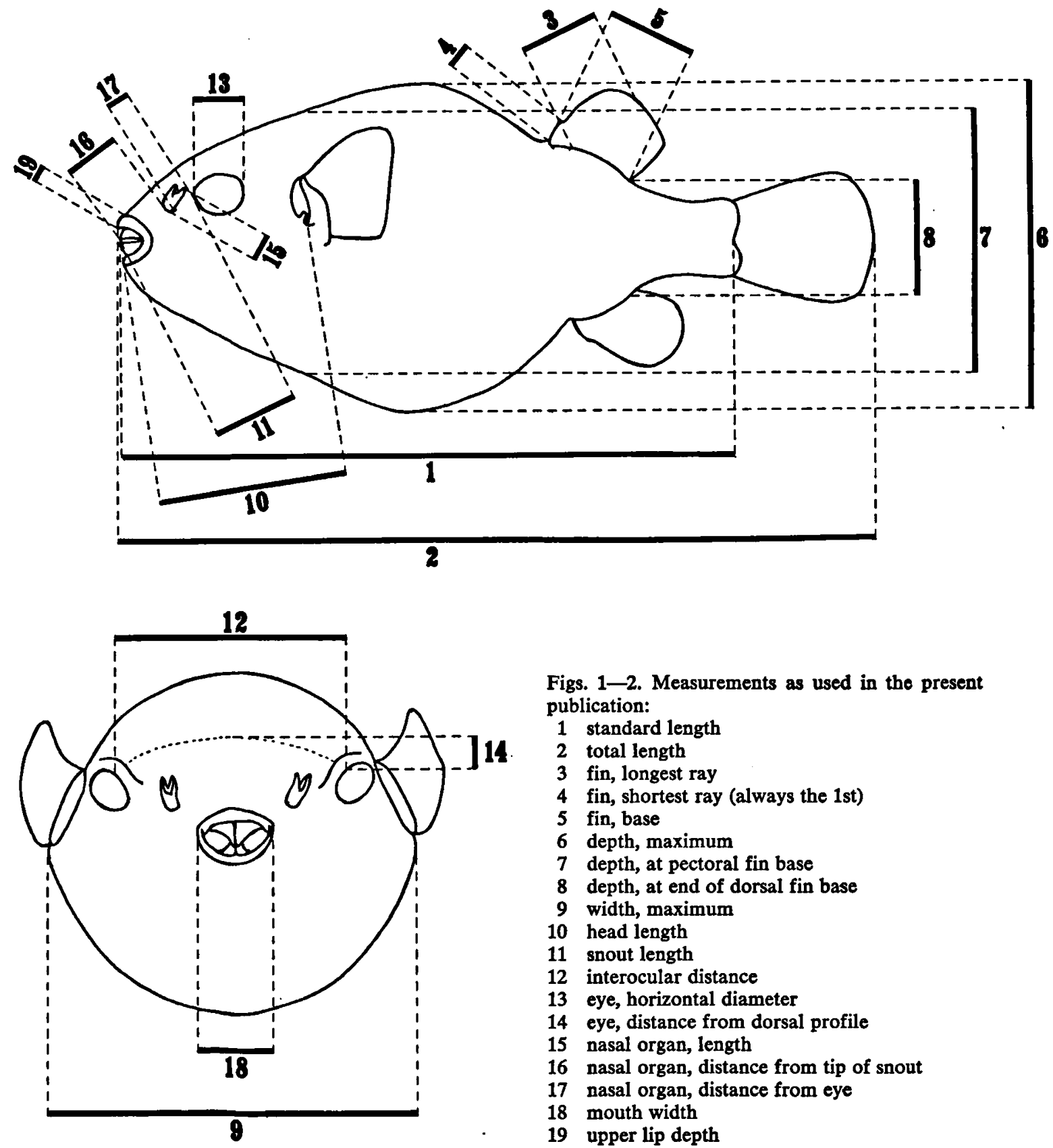

Figs. 1-2. Measurements as used in the present publication:

1 standard length

2 total length

3 fin, longest ray

4 fin, shortest ray (always the 1st)

5 fin, base

6 depth, maximum

7 depth, at pectoral fin base

8 depth, at end of dorsal fin base

9 width, maximum

10 head length

11 snout length

12 interocular distance

13 eye, horizontal diameter

14 eye, distance from dorsal profile

15 nasal organ, length

16 nasal organ, distance from tip of snout

17 nasal organ, distance from eye

18 mouth width

19 upper lip depth 
this is indicated. Not all indications were checked: they merely are given for the sake of convenience to the reader. If the material recorded represents or contains type material this is indicated as such.

Descriptions. - Measurements were taken with dial callipers, in accordance with figs. 1-2. With the exclusion of total length measurements, the anteriormost point of the teeth was considered the anteriormost point of the body. Width and depth were taken at three different points to compensate for the inexactitudes due to the various degrees of inflation of the belly region. Morphometrics of individual characters are listed only when they were taken in at least 50 percent of the specimens examined. If a separate description of type material is given, the data on this nevertheless are incorporated in the general description of the species, unless stated otherwise. Fin ray counts were made with the aid of a binocular dissecting microscope. In case of doubt whether or not the foremost structure in a fin should be regarded a true fin ray or whether or not the last ray(s) is (were) divided to the base and should be counted separately, the maximum possible count is given in the description. Only the first one or more unbranched rays are indicated as such, in words or in roman numerals, while the last one or more unbranched rays are not indicated as such.

Figures. - If possible and opportune, the nasal organ and both the lateral and dorsal view are given, since lack of one of these in earlier descriptions represents a major source of confusion.

\section{ABBREVIATIONS}

$\begin{array}{ll}\text { hl } & \text { head length } \\ \text { m } & \text { mean value } \\ \text { sl } & \begin{array}{l}\text { standard length } \\ \text { total length }\end{array} \\ \text { tl } & \\ \text { A } & \text { anal fin } \\ \text { D } & \text { dorsal fin } \\ \text { N } & \text { number of specimens examined } \\ \text { P } & \text { pectoral fin }\end{array}$

AMNH American Museum of Natural History (New York)

AMS Australian Museum (Sydney)

ANSP Academy of Natural Sciences (Philadelphia)

BFB Bureau of Fisheries (Bangkok)

BMNH British Museum (Natural History) (London)

DNHM Darjeeling Natural History Museum

FFKU Faculty of Fisheries, Kasetsart University (Bangkok)

FMNH Field Museum of Natural History (Chicago)
IMC Indian Museum (Calcutta) $(=\mathrm{ZSI})$

IOI Institut Océanographique de l'Indochine (Cauda)

ITA Instituut voor de Tropen (Amsterdam) (ex KMA)

KMA Koloniaal Museum (Amsterdam) (= ITA)

LOZB Laboratorium voor het Onderzoek der Zee (Batavia $=$ Djakarta)

MHNL Muséum d'Histoire Naturelle de la ville de Lyon

MNH Hungarian Natural History Museum (Budapest) (= TMKB)

MNHN Muséum National d'Histoire Naturelle (Paris)

MPD Muséum de la Porte Dorée

MSNG Museo Civico di Storia Naturale "Giacomo Doria" (Genova)

NAM Natura Artis Magistra (Amsterdam)

NMB Naturhistorisches Museum (Basel)

NMS National Museum (Singapore)

NMW Naturhistorisches Museum (Wien)

PBSF Philippine Bureau of Science, Section of Fisheries (Manila)

PFCM Philippine Fisheries Commission (Manila)

RMNH Rijksmuseum van Natuurlijke Historie (Leiden)

RSM Royal Siamese Museum (Bangkok)

SM Selangor Museum

SMF Natur-Museum und Forschungs-Institut Senckenberg (Frankfurt am Main)

SMM Zoologische Staatsammlung des Bayerischen Staates (München)

TF Tropicarium Frankfurt

TMKB Természettudományi Múzeum Könyvtára (Budapest) $(=\mathrm{MNH})$

ZMA Zoölogisch Museum Amsterdam = Instituut voor Taxonomische Zoölogie (Amsterdam)

ZMH Zoologisches Staatsinstitut und Zoologisches Museum (Hamburg)

ZMUG Zoology Museum of the University of Gorakhpur

ZSI Zoological Survey of India (Calcutta)

\section{ACKNOWLEDGEMENTS}

I would like to thank the following persons and institutions who made the present study possible:

Dr. H. Nijssen for giving access to all facilities of ZMA and helping in many other ways; Dr. J. C. Tyler of the Lerner Marine Laboratory of the AMNH for carefully reading the manuscript and giving valuable suggestions for alterations; Dr. M. Boeseman for giving access to the collections of RMNH, loaning specimens and giving valuable information on Bleeker Collection specimens; Dr. P. H. Greenwood, Mr. J. Chambers, and Mr. G. Howes for giving access to the collections of $\mathrm{BMNH}$, and loaning specimens; Dr. M. L. Bauchot (MNHN) for loaning specimens and giving valuable collecting data; Miss C. Smulders and colleagues (ITA) for giving access to the files and cartographic collections of KMA; Dr. E. R. Alfred (NMS), Dr. J. E. Böhlke (ANSP), Dr. L. David (MHNL), Dr. A. Kapur (ZSI), Dr. P. Kähsbauer (NMW), Dr. W. Klausewitz (SMF), Dr. W. Ladiges (ZMH), Dr. A. G. Menon (ZSI), Dr. I. A. Ronquillo (PFCM), Dr. E. Sutter (NMB), Dr. F. Terofal (SMM), and Dr. L. P. Woods (FMNH) for loaning specimens and 
providing information. A grant for the publication of this review from the Netherlands' Organization for the Advancement of Pure Research (ZWO) is gratefully acknowledged.

\section{TAXONOMIC PART}

\section{Genus Tetraodon}

The genus was established by Linnaeus in 1758 (later frequently misspelled Tetrodon). According to Tyler (1964: 121) the type species is generally taken to be $T$. lineatus, an African representative.

Several authors have made attempts to split the genus. The validity of their nominal genera and subgenera is a complicated affair. The concept presently adopted by most ichthyologists is the one by Fraser-Brunner (1943). Herein the genus is subdivided in three subgenera: Monotretus Bibron, 1855, Chelonodon Müller, 1839, and Tetraodon, the last subgenus only comprising African species. This subdivision, other than the distinction between genera, was based mainly on the form of the nasal organ and the distribution of the prickles. Fraser-Brunner (1943: 14) does not consider the form of the nasal organ an important enough character to establish genera "forming as they do a developmental series among a group of species which are otherwise of closely similar structure". Unfortunately, the FraserBrunner concept for the two Asiatic subgenera seems to be wrong, according to Tyler (1964: 125126). He considers Monotreta a synonym of Chelonodon and concludes by stating that "the present concept of Chelonodon will undoubtedly have to be changed".

As the present study does not consider osteological characters, it is not proper to interfere in the discussion on the validity of generic and subgeneric names. In this paper the Fraser-Brunner definition of Tetraodon is followed with one exception: $T$. patoca Hamilton, 1822, is not considered, both for taxonomic and practical reasons. $T$. patoca is quite different from the other Tetraodon species listed by Fraser-Brunner, in its general body form (which is much more elongate), the form of the nasal organ (which does not fit in the "developmental series"), and the distribution pattern (ranging from Africa to East Asia). The practical reason is that the distribution area is of such a great dimension and the number of closely allied nominal species is so high that this nominal species needs an intensive study of its own.

The definition of the genus, modified from Fraser-Brunner (1943), thus becomes:

A genus of the family Tetraodontidae with the sphenotic expanded laterally beyond frontal to form a broad, flattened lobe; orbital roof scarcely arched, the lateral ethmoid not bent down before the eye, not forming an olfactory forameh; mesethmoid broad; upper lateral line not reaching end of tail, curved down above anal fin to meet lower line, which extends forward beyond the point of union; 19 vertebrae; dermal ossifications of back bearing simple prickles, evenly scattered; spines on side small, closely set; dorsal fin maximally counting 16 rays; nasal organ an elevated tube, terminally often divided into two lips or lobes which may nearly reach the basis.

This definition includes all Asiatic Tetraodontidae occurring (if not exclusively) in fresh waters, with the exception of Chonerhinus naritus (Richardson, 1848), C. modestus (Bleeker, 1850), Chelonodon or Monotreta patoca (Hamilton, 1822), and Sphoeroides ocellatus (Linnaeus, 1766). The first two species can be recognized by their high (25-38) number of dorsal fin rays, the third by its nasal organ consisting of a depression, surrounded by a low rim, produced into a posterior and an anterior flap, the fourth by its nasal organ being a low papillum, pierced by two openings.

For the sake of convenience the species in this paper are grouped into the following speciesgroups:

- cutcutia-group: T. cutcutia, T. lorteti, T. travancorius

- leiurus-group: T. palembangensis, T. leiurus,

T. fangi

- erythrotaenia-group: T. erythrotaenia

- fluviatilis-group: $T$. kretamensis, $T$. nigroviridis, $T$. fluviatilis fluviatilis, $T . f$. sabahensis, T. steindachneri

- waandersii group: T. waandersii.

\section{KEY TO THE SPECIES-GROUPS, SPECIES AND SUBSPECIES}

1 - Nasal organ a short, rounded tube with a terminal opening, not or only slightly two-lipped (cutcutiagroup) $\ldots \ldots \ldots \ldots \ldots \ldots \ldots \ldots \ldots \ldots \ldots 2$

- Nasal organ a short or oblong, slightly or strongly compressed tube, the distal $1 / 3-5 / 6$ of which is divided into two lips or lobes ............4

2 - D 7-8; A 8; P 16-17 .. T. travancorius (p. 101) D $10-13 ;$ A $10-12 ;$ P $14-21 \ldots \ldots \ldots \ldots$. 
3 - Height of nasal tube 2 or more in its diameter; sides of body mostly with a dark ocellus; colour pattern not strikingly sexually dimorphic; D 10-11; A 10; P 18-21 .............. T. cutcutia (p. 95)

- Height of nasal tube nearly 1 in its diameter; sides of body without a dark ocellus; colour pattern strikingly sexually dimorphic; D 11-13; A 10-12; P $14-16 \ldots \ldots \ldots \ldots \ldots \ldots$. . lorteti (p. 97)

4 - Nasal tube divided over $1 / 3-1 / 2$ of its length; apposed surfaces of nasal lobes never with spongy tissue; sides with many polygonal dark spots leaving only lighter network or with wide-meshed dark network enclosing some dark rounded spots; head deflated (leiurus-group) ............. 5

- Nasal tube divided over $(1 / 3)-1 / 2-4 / 5$ of its length; apposed surfaces of nasal lobes sometimes with spongy tissue; sides coloured otherwise; head mostly rounded $\ldots \ldots \ldots \ldots \ldots \ldots \ldots \ldots 7$

5 - Sides with wide-meshed dark network, 3-18 of the meshes enclosing one, sometimes two, rounded, dark spots or ocelli; body spines often in deep dermal pits, with small dermal papillae; D 12-14; A 10-12; P 21-23 .. T. palembangensis ( $\mathrm{p} .104$ )

- Sides with many polygonal spots leaving lighter network; back often with one or two dark patches, sometimes with many oval, whitish spots; body spines mostly in only superficial dermal pits; D $12-15$; A $10-12$; P $21-24 \ldots \ldots \ldots . .66$

6 - One of the lateral spots always formed into a darker and bigger ocellus; snout $2.7-2.9$ in $\mathrm{hl}$; maximum known sl $61 \mathrm{~mm}$; D 12-14; A 10-11; P 21-23 .............. T. fangi (p. 112)

- Sides with or without lateral ocellus; snout 2.0 2.4 in hl; maximum known sl $153 \mathrm{~mm}$; D 13-15; A $10-12 ;$ P $21-24 \ldots . . .$. T. leiurus (p. 108)

7 - Sides with a single or double longitudinal band separating an uniformly dark dorsal region from a differently coloured ventral region; D 9-11; A 8-9; P 18-19 (erythrotaenia-group) ..........

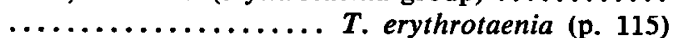

- Sides sometimes with a simple longitudinal band, but otherwise differently coloured; D 11-16; A $10-14 ;$ P $16-24 \ldots \ldots \ldots \ldots . . . \ldots \ldots . .8$

8 - Sides with about 35 dark transverse bandelets on upper parts; back dark; D 12; A 11; P 16 (waandersii-group ............ T. waandersii (p. 134)

- Sides and back with dark spots and/or blotches (fluviatilis-group); D 11-16; A 10-14; P 18-24.. 9

9 - Sides with 2-4 dark ocellated spots and with irregular whitish lines, some of them broken into spots; back with similar lines and with three dark patches; D 13-15; A 11-13; P 18-21 ...... $\ldots \ldots \ldots \ldots \ldots \ldots$ T. steindachneri (p. 132)

- Sides without whitish markings; back with or without whitish markings and dark patches; D 11-16; A 10-14; P 18-24 .............. 10

10 - Back and sides with more or less regular, rounded spots, which are more or less evenly scattered, and only occasionally confluent, never forming broad blotches; apposed surfaces of nasal lobes spongy in $50 \%$ of specimens $\geqslant 60 \mathrm{~mm} \mathrm{sl}$; D 12-14; A $10-12 ;$ P $18-23 \ldots \ldots$. . . nigroviridis (p. 123)

- Back with dark transverse markings or with large dark blotches; nasal lobes with or without spongy tissue; D 11-16; A 10-14; P 18-24 ....... 11
11 - Back with dark transverse bands, often including a V-shaped marking behind eyes; apposed surfaces of nasal lobes always without spongy tissue in all specimens $\geqslant 60 \mathrm{~mm}$ sl; often a broad dark longitudinal band separating dark colour of upper parts from light colour of belly; D 11-13; A 10; P 18-19 ........... T. kretamensis (p. 121)

- Back with 3-4 dark blotches in longitudinal row; apposed surfaces of nasal lobes with spongy tissue in $85 \%$ of specimens $\geqslant 60 \mathrm{~mm}$ sl; never a dark longitudinal band; D 13-16; A 11-14; P $19-24 \quad \ldots \ldots \ldots \ldots \ldots \ldots \ldots \ldots \ldots \ldots 12$

12 - Head $2.4-3.1$ in sl; D $13-16$; A $11-14 ;$ P 1924; India, Burma .. T. fluviatilis fluviatilis (p. 127)

- Head $2.1-2.3$ in sl; D 13-15; A 11-12; P 2122; East Malaysia..T. fluviatilis sabahensis (p. 130)

\section{cutcutia-g rou p}

Diagnosis. - Tetraodon species with the nasal organ formed by a cylinder with one terminal opening, the border of which is not or scarcely two-lipped. D 7-13; A 8-12; P 14-21. Three species: $T$. cutcutia, T. lorteti, T. travancorius.

Discussion. - The group is recognized by several authors as a distinct genus or subgenus, by the name of Leiodon Swainson, 1839, Leiosomus Swainson, 1839, or Monotreta Bibron. 1855. The difference with other Tetraodon species, notably those of the leiurus-group, however, is gradual, as some of the latter species have their nasal organs two-lipped for only one-third of their length. Benl (1957b) proposed the new genus Carinotetraodon for his species chlupatyi (a junior synonym of $T$. lorteti) based on the ability of the species to erect a low mid-dorsal and mid-ventral ridge. In my opinion one should await the results of osteological studies before adopting this view.

Within the group at least 13 names were proposed. Three of these were published as early as 1822 by Hamilton, from the Ganges River system: $T$. cutcutia, $T$. caria, and $T$. gularis. The first of these - also printed as first of the three is easily recognizable from the figures accompanying the description and is generally accepted as a valid species. The drawings of the latter two were retained by the Bengal government and could not be incorporated in Hamilton's publication. Of these two only one later was refound. It was then published by Hora (1929: pl. 16, figs. 2-3). According to Hora it represents $T$. caria because the drawing carried the name "Tetradon Kariya Phoksa", the last words being, as recorded by Hamilton in his original notes, 
the local equivalent of $T$. caria. This view, however, is contradicted by the description by Hamilton, in which $T$. caria is characterized by the lack of a lateral black spot; the figures reproduced by Hora show a distinct spot. In Day's opinion, as cited by Hora, the figures represent T. cutcutia. This would imply that Hamilton had commissioned four drawings for a single species, a less probable proposition. To me it seems most likely that the figures represent $T$. gularis as this would match the description without the improbabilities emanating from Hora's and Day's views. Anyway, differences between the four figures and between the three descriptions are too slight to distinguish separate species. Hamilton himself remarks on $T$. caria (1822: 9): "I cannot take upon myself to say, whether it is a distinct species or a mere variety", and on $T$. gularis he admits (1822: 10) "Its being ... a mere variety is still more probable". Given these statements, the absence of type material and the loss of exactly definable illustrations, it seems most reasonable to synonymize the three nominal species under the heading of $T$. cutcutia, as has been done ever since 1822 - until 1959. In that latter year Le Danois resurrected the name $T$. caria (as Monotreta caria) for $T$. lorteti Tirant, 1885, without giving any arguments for doing so. According to Hamilton $T$. caria is found in the Ganges River system, has about 18 pectoral fin rays, and has jaws of nearly equal length. $T$. lorteti, in contrast, is not known from India, has (14)-15-(16) pectoral fin rays $(\mathrm{N}=42)$, and has its mouth directed upwards.

The name gularis (also in the genus Monotreta) was also resurrected by Le Danois (1959) and used for $T$. cutcutia, the name of the latter species being reserved by her for $T$. leiurus and $T$. palembangensis. These two Bleeker species, however, prove to be dissimilar from $T$. cutcutia by taking a second's look at the figures in the "Gangetic Fishes" (Hamilton, 1822) and those in the "Atlas Ichthyologique" (Bleker, 1865a).

The name Leiodon marmoratus or Leiosomus marmoratus Swainson, 1839, is a nomen nudum; it was synonymized by Bleeker (1865a) with $T$. cutcutia. Some time later (1865c) Bleeker himself attributed a nomen nudum - Chelonodon dumerili - when he promised to describe a new species from Thailand, a promise which never was redeemed. According to the publication the material was deposited in MNHN. Le Danois $(1959,1961)$ recognized it in the collections of MNHN as no. 2007. Her redetermination reads Monotreta caria Hamilton, 1822, which in my concept is $T$. lorteti, Tirant, 1885 .

$T$. lorteti proved a valid species after examination of the syntypic material. Important characters discriminating it from $T$. cutcutia are the pectoral fin ray counts (15-16 against 18-21 in $T$. cutcutia), the length of the nasal organ (1 in diameter against 2 in diameter) and the lack of a lateral ocellus. In scientific circles the species is better known as $T$. borneensis, while in aquarium circles it is popular under the names of Tetraodon somphongsi Klausewitz, 1957, or Carinotetraodon chlupatyi Benl, 1957. Both the first and the last names proved to be junior synonyms of $T$. lorteti after examination of the type material. Carinotetraodon chlupatyi was declared a synonym of $T$. somphongsi - described only some months earlier - by its own author, Benl, in 1959. In aquarium observations both nominal species and a third form, provisionally named $T$. werneri, proved to be physiological forms of a single species, the differences being due to age, sex, food conditions, type of vegetation, and composition of the aquarium community. $T$. werneri proved to represent the juveniles and females, $T$. somphongsi representing the younger males and $T$. chlupatyi the mature males. This was confirmed by sex determination on 200 specimens by Somphongs (cited in Benl, 1959). Differences in colour pattern - although not related to sex differences - were earlier recorded by Hora (1923b, 1924), who, however, wrongly identified his specimens as $T$. palembangensis. Probably not acquainted to the work of Benl and later authors, the female-juvenile form of $T$. lorteti was described as a separate new species - Monotreta tiranti - by d'Aubenton \& Blanc (1966), who named the male form Monotreta caria, following Le Danois (1959). The incorrectness of this view was recently emphasized by Sontirat et al. (1971) who found the colour pattern during field observations to be strongly dependent on surroundings, behaviour and light intensity.

The third and last species recognized as valid in the cutcutia-group, $T$. travancorius, was described by Hora \& Nair (1941) from India. Although the holotype and paratypes all are less than an inch in length, there can be little doubt about them representing a separate species because of the strikingly low fin ray counts: D 7-8; A 8 (T. cutcutia: D 10-11; A 10; T. lorteti: D 11-13; A 10-12). Although in the original description the collector of the specimens, K. B. Nair, is 
quoted stating (1941: 393): "I am sure bigger specimens, if there were any, would not have been overlooked", I am quite sure the species can grow bigger as the relative eye-diameter is quite high, which generally in Tetraodon indicates that the specimens are juvenile. A juvenile state of the type series cannot, however, be a strong argument against the separate specific status as the number of fin rays in my experience is not or scarcely related with age in Tetraodon. On the other hand, the supposed youthfulness most probably indicates that the colour description as given by Hora \& Nair is not useful as a specific character. This last impression is strengthened by the fact that the paratypes show a considerable variability in colour pattern.

Finally it must be remarked that the species recorded by Axelrod et al. (1967) to be T. cutcutia is not that, but $T$. fangi.

\section{Tetraodon cutcutia Hamilton, 1822.}

Figs. 3-5.

\section{Tetrodon cutcutia}

HAMILTON, 1822: 8-9, 362, pl. 18 fig. 3 (original description, lateral and dorsal view figured; India, West Bengal or Bangla Desh: Ganges River system; no material known).

GÜNTHER, 1870: 290 (description; India: Calcutta; material in BMNH) (in subgenus Monotretus).

DAY, 1878: 703, pl. 182 fig. 5 (description; India: Orissa \& India: Assam \& Bangla Desh) (in subgenus Monotretus).

VINCIGUERRA, 1883: 660 (description; Burma: Irrawaddy River near Minhla; material in MSNG).

DAY, 1889: 493 (description and material after Day, 1878).

VINCIGUERRA, 1890: 231 (description; Burma: Rangoon \& Burma: Mandalay \& Burma: Bhamo \& Burma: Meetan; material in MSNG).

D'ABREU, 1925: 711 (listed; India: Ganges River system, Ghogra River, Newajitola).

RANDOW, 1934: 561-563, Abb. 1 (field observations, aquarium data; Ceylon; no material).

BECK, 1950: 240, fig. 101 (description, aquarium data; no material).

LADIGES, 1954: 67, fig. 64 (aquarium data; no material).

Tetrodon caria

Hamilton, 1822: 9-10, 362 (original description, discussion on differences with $T$. cutcutia; India: Bihar, Ganges River system, Kosi River; no material known).

Tetrodon gularis

HAMILTON, 1822: 10, 362 (original description, discussion on differences with $T$. cutcutia and $T$. caria; India, West Bengal or Bangla Desh: Ganges River system, including Kosi River; no material known).

Leiosomus marmoratus

SWAINSON, 1839: 328 (listed as representative of genus; no material) (nomen nudum).

Tetraödon cutcutia;

BLEEKER, 1853a: 14, 29, 78-79, 160 (description; India:
Calcutta, Hooghly River; material partly in RMNH reg. no. 7345 , partly in ZMA, reg. no. 110.225).

Monotrète cutcutia;

BIBRON (in: DUMÉRIL), 1855: 280 (listed as type species for Monotrète; India or Bangla Desh: Ganges River system; material in MNHN, reg. no. B 1470).

Arothron? cutcutia;

BLEEKER, 1859a: 267 (listed; no additional material).

Leiosomus cutcutia;

BLYTH, 1860: 173 (listed; Burma: Moulmein).

Leiodon cutcutia;

GILL, 1892: $710-711$ (listed as representative of genus; no material).

Tetraodon cutcutia;

Prashad \& MUKerJi, 1929: 162, 163, 166, 169, 223 (description; Burma: Indawgyi Lake and associated rivers; material in ZSI).

Shaw \& Shebbeare, 1938: 8, 124-125, pl. 4 figs. 12-13, text-fig. 126 (description; North Bengal: Terai \& North Bengal: Duars; material in ZSI and DNHM).

HoRA \& NAIR, 1941: 388-391 (listed; India: Travancore; material in ZSI) (in subgenus Monotretus).

FrASER-BRUNNER, 1943: 14 (listed as representative of genus and subgenus; no additional material) (in subgenus Monotretus).

Breder \& Clarke, 1947: 308 (note on reproduction; uU additional material).

BENL, 1956: 144-146, 175, 202 (description, aquarium data; no material).

BENL, 1957a: 65, Abb. 4 (in discussion on differences with T. leiurus brevirostris Benl, 1957; no material).

MerCKENS, 1958: 52, 53, 54 (description, aquarium data; no material).

SterbA, 1959: 634, 637, Taf. 256, 273 (description, aquarium data; no material).

Hervey \& Hems, 1963: 385 (description, aquarium data; no material).

SRIVASTAVA, 1968: 146-147, fig. 86 (description; India: Gorakhpur, Ramgarh Tal; material in ZMUG).

Monotretus cutcutia;

Munro, 1955: 282, pl. 55 fig. 820 (description; Ceylon; no material).

Monotreta gularis;

LE DANOIS, 1959: 21, 152-153, 246-247, 250-251, 253, fig. 84E (description, nasal organ figured, discussion on osteology, evolution; Ganges River system; material in MNHN, including MNHN B 1470).

LE DANOIS, 1961: 465 (in type list of MNHN, listed as type species for Monotreta).

General description. -

General morphology. - Body compressed laterally; dorsal profile rising nearly rectilinear to midst of back, from there sloping gradually to caudal fin; interorbital flat; body spines apparently absent; mouth terminal, directing forwards or downwards; no prominent chin; lower border of eye above level of mouth corner, upper border not interfering with dorsal profile; nasal organ a very short tube, height 2 or more in diameter, with one terminal opening, at the most only slightly lobed; no skin folds on back or belly. 

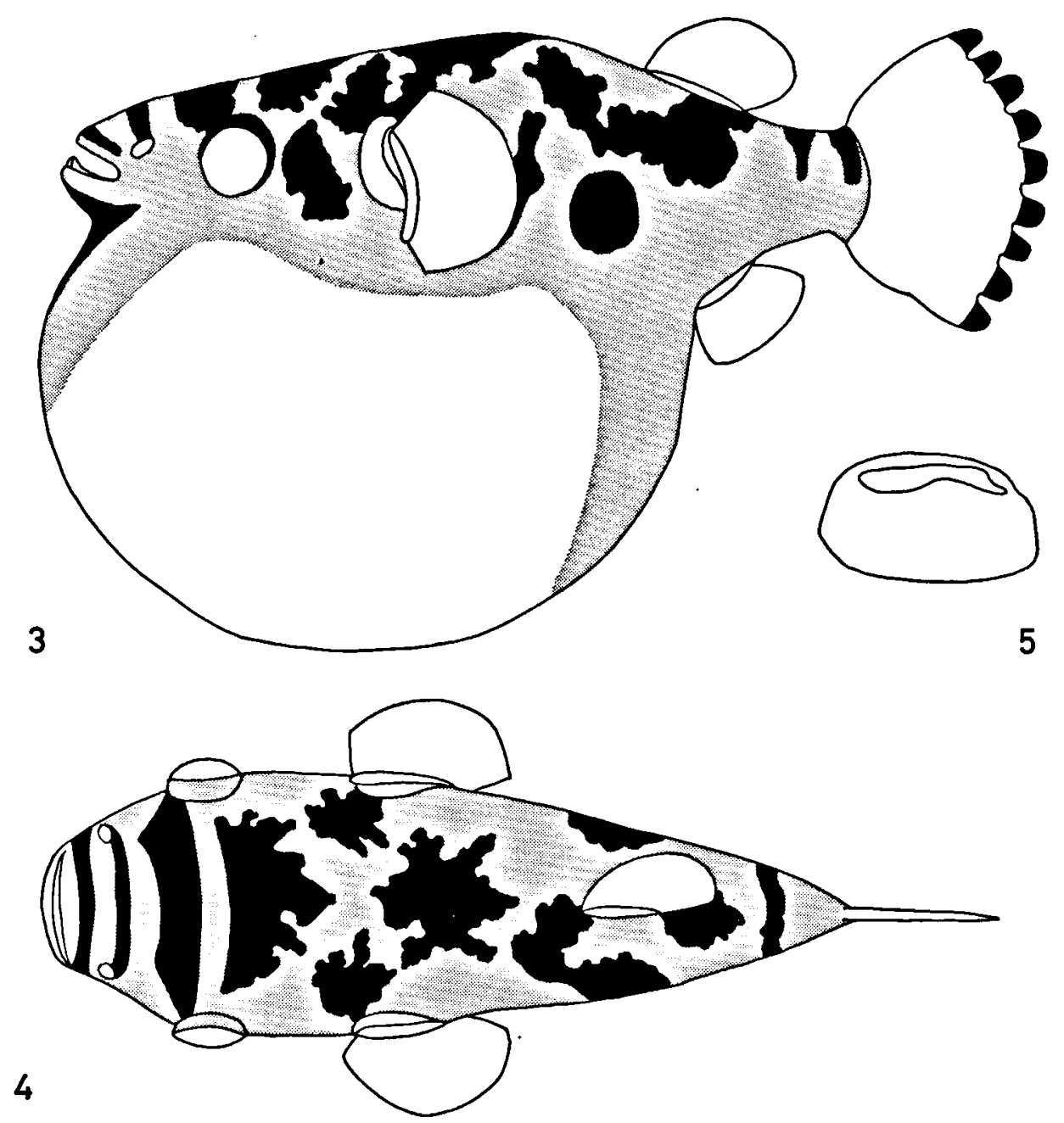

Figs. 3-5. Tetraodon cutcutia Hamilton, 1822.

Fig. 3. Lateral view of "iconotype" after Hamilton (1822: pl. 18, fig. 3).

Fig. 4. Dorsal view of "iconotype" after Hamilton (1822: pl. 18, fig. 3).

Fig. 5. Nasal organ of ZMA 110.225 , sl $45 \mathrm{~mm}$.

Colour in alcohol. - Ground colour of upper parts grey or greenish, lower parts whitish; back with dark cloudy or reticulated markings, sometimes descending to sides; a light interocular band; sides mostly with a dark meshwork and with a dark ocellus just in front of dorsal and anal fins; sometimes a spot (red in life) on chin; caudal fin bordered with a darker band (red in life) or all dusky; other fins plain.

Morphometrics. - Maximum sl ca. $95 \mathrm{~mm}$; dorsal fin rays 10-11; anal fin rays 10; pectoral fin rays 18-21; head length ca. 2.2 in sl; snout length ca. 2.2 in $\mathrm{hl}$; mouth width ca. 3.6 in hl.

ZMA 110.225; 1 specimen, sl 45 mm; India: Calcutta,
Hooghly River; coll. T. Cantor, ca. 1849; Bleeker Collection.

SMM 23917; 1 specimen, sl $60 \mathrm{~mm}$; India: Calcutta; live imported.

Note. - Descriptions were chiefly made from literature.

Description of the holotype. -

A holotype in the sense of the International Code of Zoological Nomenclature does not exist, as Hamilton did not leave any known specimen of the species. Generally, however, one accepts Hamilton's figures as the "holotype" ("iconotype"). As $T$. cutcutia is the first species of the cutcutiagroup described in Hamilton, 1822, and as Ham- 
ilton is the first author after 1758 describing Indian Tetraodon species there can be only slight doubt about the identity of the species illustrated as $T$. cutcutia. Designation of a neotype is not necessary at the moment and thus prohibited by the Code. Hamilton's figures (pl. 18 fig. 3) reproduced hereby in adaptated form - and his description remain the basis for the species.

Distribution. - T. cutcutia is known with certainty from East India, Ceylon, Bangla Desh, and Burma.

Etymology. - Like most of the names of species described by Hamilton, the name cutcutia is derived from a local name, being, according to Hora (1929), "kotkotiya".

\section{Tetraodon lorteti Tirant, 1885.}

Figs. 6-9.

\section{Chelonodon Dumerili}

BLEEKER, 1865c: 33 (no description; Thailand; material, according to Le Danois, 1959 \& 1961 in MNHN, reg. no. 2007, from Ayuthia) (doubtful synonym).

BLEEKER, 1865d: 172 (listed; no additional material).

Tetrodon Lorteti

TiRanT, 1885: 175 (in ed. 1929: 96) (original description; Vietnam: surroundings of Thu dau mot; material in MHNL, reg. no. 3907 , lectotype and paralectotypes, and in MNHN, reg. no. 37-60, paralectotype) (in subgenus Crayracion).

Tetrodon borneensis

REGAN, 1902: 303, pl. 24 fig. 3 (original description; East Malaysia: Sarawak; material in BMNH, reg. no. 1894.1.20: 16-17, syntypes).

Tetraodon palembangensis;

HORA, 1923b: 183-184 (description of two colour phases; Thailand: Nontaburi; material at least in part in ZSI, reg. no. F 10612/1).

HORA, 1924: 499, fig. 9a, b (emendated description of two colour phases, both phases figured; Thailand: Nakon Lampang; material at least in part in ZSI, reg. no. F 10471/1).

Tetrodon lorteti;

BONNET, 1927: 367 (publication not seen by me).

CHEVEY, 1932: 31 (listed; no additional material).

Tetraodon borneensis;

FrASER-BRUNNER, 1943: 14 (listed as representative of genus and subgenus; no additional material) (in subgenus Monotretus).

DE BEAUFORT, 1962: 398 (description after syntypes, discussion on differences with original description; no additional material) (in subgenus Monotretus).

Tetraodon somphongsi

KLAUSEWITZ, 1957b: 205-208, Abb. 1, 2 (original description, discussion on ethology, physiological colour changes and differences with T. cutcutia and T. leiurus; Thailand, live imported; material in SMF, reg. no. 4083 , holotype, and $4084-4086$, paratypes; 2 topotypes still living at time of description).

KLAUSEWITZ, 1957c: 115-116, 2 figs. (compilation of
Klausewitz, 1957b; no additional material).

BENL, 1957b: 1-4 (in discussion on differences with Carinotetraodon chlupatyi Benl, 1957; no additional material).

BeNL \& CHLUPATY, 1957: 227-229 (ethological and morphological comparisons with Carinotetraodon chlupatyi Benl, 1957 and T. werneri provisionary name; no additionai material).

OSTERMÖLLER, 1957: 288-290, 1 fig. (aquarium data; no material).

MERCKENS, 1959: 171, 1 fig. (description, aquarium data; no additional material).

SONTIRAT et al., 1971: 5-6 (description of living and preserved specimens, discussion on variability of colour pattern; Thailand: $50 \mathrm{~km} \mathrm{~S}$. of Krung Thep; material in FFKU).

Carinotetraodon chlupatyi

BENL, 1957b: 1-4, 1 fig. (original description of genus and species, discussion on colour changes and morphology; Thailand: near Krung Thep; material living at time of description, at present preserved in SMM, reg. no. 15419, holotype).

Benl \& Chlupaty, 1957: 227-229, Abb. 1, 2 (aquarium data, discussion on differences with $T$. somphongsi Klausewitz, 1957 and $T$. werneri provisionary name; emendated type locality: Thailand: $400 \mathrm{~km} \mathrm{~N}$. of Krung Thep; material including holotype described alive).

Tetraodon werneri

BENL \& CHLUPATY, 1957: 227-229 (description, aquarium data; explicitly used as a provisionary name, not as a new species name; no material).

Carinotetraodon somphongsi;

BENL, 1959: 42-44 (lumping of $T$. somphongsi Klausewitz, 1957, T. werneri provisionary name and Carinotetraodon chlupatyi Benl, 1957 based on aquarium observations concerning individual variability; emendated type locality: Thailand: Chao Phaya River system, Tachin $=$ Nakon Chaisi River, $38 \mathrm{~km} \mathrm{~N}$. of Krung Thep; no additional material).

STERBA, 1959: 635-636, Taf. 276 (description, aquarium data; no material).

VAN DER VluGT, 1968: 218-224, figs. p. 219, 221 (description, aquarium data, discussion on colour changes; Thailand \& East Malaysia, Sarawak; material imported alive).

Monotreta caria;

Le Danols, 1959: 132, 152-154, 246, 247, 251, 254, fig. 84F, 107, 108 (description; skull, nasal organ, and lateral view figured; discussion on osteology, zoogeography, and evolution; no localities mentioned; material should include type material of Chelonodon dumerili Bleeker, nomen nudum and $T$. lorteti).

Le DaNoIs, 1961: 466 (in type list of MNHN, listed as senior synonym of Chelonodon dumerili Bleeker, nomen nudum, and $T$. lorteti; no additional material).

D'AUBENTON \& BLANC, 1966: 555-556, fig. 1 (description; Cambodia: Prek Tamen, Snoc Trou; material in MNHN, reg. no. 66-52).

\section{Monotreta tiranti}

D'AuBenton \& Blanc, 1966: 556-558, fig. 2 (original description, discussion on differences with $T$. palembangensis; Cambodia: Tonle Sap $\mathrm{km} \mathrm{9}$; material in MNHN, reg. no. $66-48$, holotype, and $66-49 / 51$, paratypes). 


\section{General description. -}

General morphology. - Body oblong, compressed laterally, most strongly compressed at caudal peduncle; dorsal profile arched, highest at origin of dorsal fin; interorbital convex, in laterally shrunken specimens with a medial groove; lateral line system indistinct; body spines small, covering back, sides and belly from nasal organs to end of anal fin base; mouth terminal, directed up. wards; a heavy chin; lower border of eye slightly above level of mouth corner, upper border not interfering with dorsal profile; nasal organ a short cylinder, nearly as high as broad, with one terminal opening, at the most only scarcely lobed, in laterally shrunken specimens situated in a longitudinal depression; males often with a ventral and dorsal median skinfold (depth $1-4 \mathrm{~mm}$ )
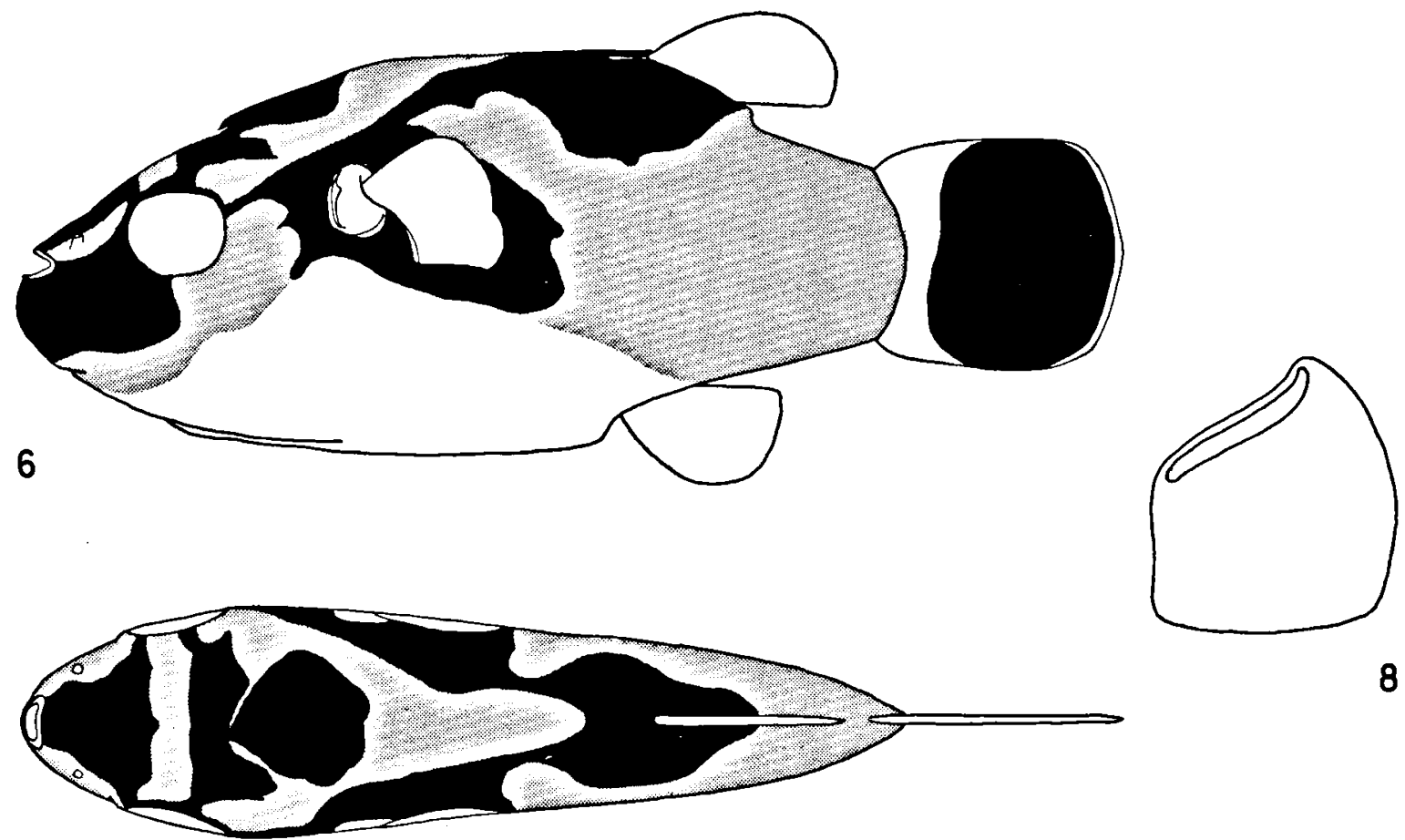

7

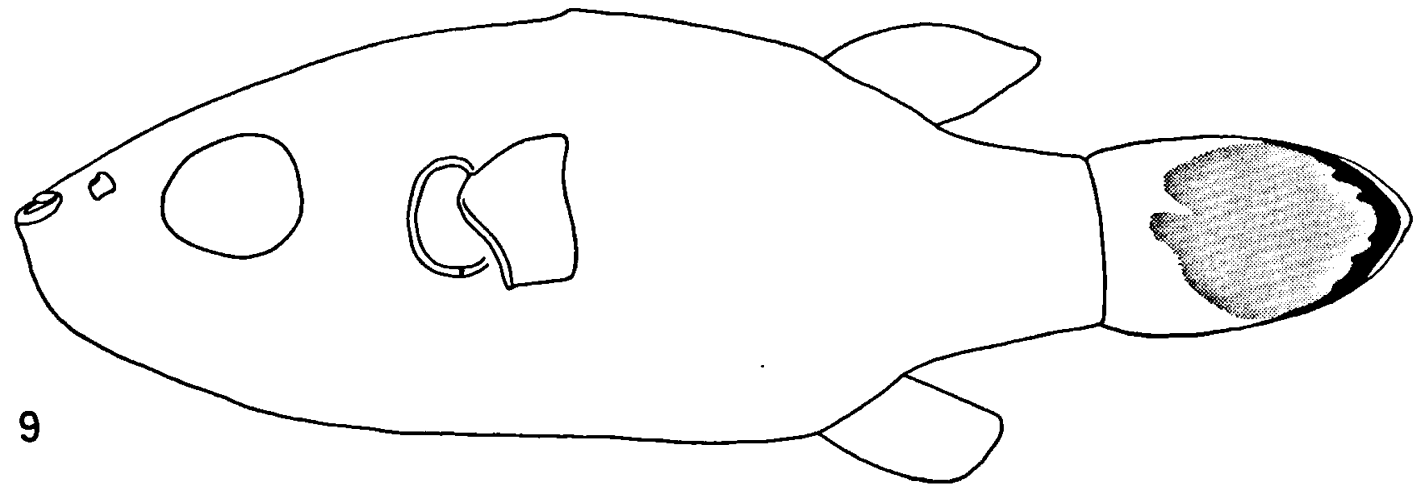

Figs. 6-9. Tetraodon lorteti Tirant, 1885.

Fig. 6. Lateral view of ZMA 110.223, sl $42 \mathrm{~mm}$.

Fig. 7. Dorsal view of ZMA 110.223, sl $42 \mathrm{~mm}$.

Fig. 8. Nasal organ of MHNL 3907, lectotype, s1 $31 \mathrm{~mm}$

Fig. 9. Lateral view of lectotype, sl $31 \mathrm{~mm}$. 
between tip of snout and dorsal fin. Anal fin sometimes accompanied ventrally by shorter, parallel skinfolds on throat.

Colour in alcohol. - Dependent upon age, sex and physiological conditions at time of killing. In dark colour phase both sexes irregularly dark. Light colour phase sexual dimorphic:

Mature males: Ground colour of upper parts tan, of lower parts lighter, border between both colours running from chin to end of anal fin base; a light band between eyes, bordered posteriorly by a trapezoid or triangular dark patch reaching to midst of back or beyond; snout dorsally dark; a dark patch on throat and chin, connected with eyes by a dark band; a dark band from posterior border of eye to origin of dorsal fin, broadening and sometimes branching posteriorly; caudal fin with narrow white terminal border, preceded by a dark transversal band of varying width sometimes occupying the larger part of caudal fin; other fins plain.

Females and juveniles: Patches and bands like in males; back and sides posterior of connecting band between eye and dorsal fin reticulated; caudal fin reticulated or densely spotted with dark, without a dark band; dorsal and anal fins with a dark rounded spot at their bases; light parts of ventral surface often with a few small dark spots or longitudinal stripes.

Note. - Colour in life is strikingly different (Klausewitz, 1957b; Benl, 1957b), the most striking differences being red (males) or partly reddish (females) dorsal and anal fins and a red ventral median stripe in many specimens.

Morphometrics (based on 42 specimens). - sl 2054 (m 36) mm; tl 26-68 (m 45) mm; dorsal fin rays $11-13$ (m 12.0) of which $1-4$ (m 2.7) unbranched, longest ray (the 6-10th) 6.4-9.1 (m 7.6) in sl, shortest ray (the 1st) $10.8-21$ (m 15.0) in sl, base 5.8-9.8 (m 7.1) in sl and 0.7-1.2 (m 0.9) in longest ray; anal fin rays 10-12 (m 11.1) of which $1-3$ (m 2.1) unbranched, longest ray (the 6-9th) 6.8-9.1 (m 7.7) in sl, shortest ray (the 1st) $10.3-17.6(\mathrm{~m} \mathrm{14.4)}$ in $\mathrm{sl}$, base $7.6-12.9$ (m 9.2) in sl and 0.9-1.6 (m 1.2) in longest ray; pectoral fin rays $14-16$ (m 15.0) of which $1-2$ (m 1.3) unbranched, longest ray (the 5-7th) 7.4 -11.1 (m 9.2) in sl, shortest ray (the 1st) 8.3-16.7 (m 12.7) in sl, base 7.7-11.6 (m 8.8) in sl and $0.8-1.3$ (m 1.0) in longest ray; depth maximum $2.0-3.0$ (m 2.7) in sl, at pectoral fin base $2.0-3.2$ (m 2.7) in sl, at end of dorsal fin base 3.2-5.2 (m 4.3) in sl; width maximum 3.0-4.2 (m 3.6) in sl and 1.1-1.8 (m 1.4) in maximum depth, at pectoral fin base $3.2-4.5$ (m 3.7) in sl and 1.02.0 (m 1.4) in corresponding depth, at end of dorsal fin base 5.6-10.6 (m 7.5) in sl and 1.3-3.0 (m 1.8) in corresponding depth; head length 2.32.8 (m 2.5) in sl; snout length $2.0-2.9$ (m 2.4) in $\mathrm{hl}$; eye horizontal diameter $2.4-4.2$ (m 3.3) in $\mathrm{hl}$, distance from dorsal profile $5.0-17.6(\mathrm{~m} \mathrm{12.1})$ in $\mathrm{hl}$; interocular distance $1.5-2.4$ (m 1.9) in hl; nasal organ length 10.9-19.6 (m 15.2) in hl, distance from tip of snout 3.3-5.9 (m 4.7) in hl, distance from eye 4.4-6.7 (m 5.8) in $\mathrm{hl}$ and $0.9-$ 2.0 (m 1.3) in distance from tip of snout; mouth width 3.3-5.7 (m 4.0) in hl; upper lip depth 6.824 (m 16.0) in hl; lower lip depth 11.3-24 (m 17.9) in hl.

\section{Material examined. -}

BMNH 1894.1.20: 16-17; 2 specimens, sl 43, $44 \mathrm{~mm}$; East Malaysia: Sarawak; coll. Bartlett (syntypes of $T$. borneensis Regan, 1902).

BMNH 1904.7.25: 49; 1 specimen, sl $53 \mathrm{~mm}$; West Malaysia: Kuala Lumpur, Selangor; ex SM.

BMNH 1906.10.29: 41-42; 2 specimens, sl 38, $43 \mathrm{~mm}$; East Malaysia: Sarawak, Sibu; coll. C. Hope.

MHNL 3907; 13 specimens, sl $20-31 \mathrm{~mm}$; see lectotype description and paralectotypes description.

MNHN 37-60; 1 specimen, sl $25 \mathrm{~mm}$; see paralectotypes description.

MNHN 56-41; 1 specimen, sl $31 \mathrm{~mm}$; Indochina; coll. Arnoult.

MNHN 66-52; 1 specimen, sl $30 \mathrm{~mm}$; Cambodia: Prek Tamen, Snoc-Trou; coll. F. d'Aubenton, 12-VII-1962.

MNHN A 5072; 6 specimens, sl 39-50 mm; Thailand: Chao Phaya River system; coll. Harmand.

MNHN A 5099; 1 specimen, sl 40 mm; Thailand; coll. Harmand.

MNHN A 5100; 1 specimen, sl 40 mm; Thailand; coll. Harmand.

SMM 15419; 1 specimen, sl $52 \mathrm{~mm}$; Thailand; imported alive, 29-I-1957; died in aquarium of P. Chlupaty, München, V-1958 (holotype of Carinotetraodon chlupatyi Benl, 1957).

ZMA 110.223; 112 specimens, sl 28-54 mm; Thailand; imported alive; died 1965 .

ZMA 110.224; 1 specimen, sl $43 \mathrm{~mm}$; imported alive; died in NAM, 1963.

ZSI F 10471/1; 1 specimen, sl $28 \mathrm{~mm}$; Thailand: Nakon Lampang; coll. N. Annandale.

ZSI F 10612/1; 1 specimen, sl $39 \mathrm{~mm}$; Thailand: Nontaburi; coll. M. Smith, 10-XII-1923.

Description of the lectotype. -

Designation. - There can be no doubt about the series used for selecting a lectotype being the original syntypical series of Tirant, as it is preserved in Lyon (MHNL), the place where he 
worked. Paris (MNHN) only possesses a single specimen, donated by MHNL. The lectotype was chosen out of the series on base of having the greatest sl.

General morphology. - In spite of the small size and the bad state of preservation, all characters mentioned in the general description - including middorsal and midventral skinfolds - are present.

Colnur in alcohol. - Due to bad preservation, colour pattern only on lateral parts of head and from there to dorsal fin; remains of black, white bordered band on caudal fin determine the lectotype to be a male.

Morphometrics. - sl $31 \mathrm{~mm}$; tl $38 \mathrm{~mm}$; dorsal fin rays iii.10, longest ray (the 9 th) $4.5 \mathrm{~mm}$ (6.9 in sl), shortest ray (the 1st) $2.2 \mathrm{~mm}$ (14.1 in sl), base $4.4 \mathrm{~mm}$ (7.0 in sl and 1.0 in longest ray); anal fin rays ii.9, longest ray (the 8 th) $3.7 \mathrm{~mm}(8.4$ in sl), shortest ray (the 1st) $2.8 \mathrm{~mm}$ (11.1 in sl), base $3.7 \mathrm{~mm}$ ( 8.4 in sl and 1.0 in longest ray); pectoral fin rays 15 , longest ray (the 5 th) $3.0 \mathrm{~mm}(10.3$ in sl), shortest ray (the 1st) $2.5 \mathrm{~mm}$ (12.4 in sl), base $2.8 \mathrm{~mm}$ (11.1 in sl and 1.1 in longest ray); depth maximum $11.1 \mathrm{~mm}(2.8 \mathrm{in} \mathrm{sl})$, at pectoral fin base $10.6 \mathrm{~mm}(2.9 \mathrm{in} \mathrm{sl})$, at end of dorsal fin base $7.0 \mathrm{~mm}(4.4 \mathrm{in} \mathrm{sl})$; width maximum $7.4 \mathrm{~mm}(4.2$ in sl and 1.5 in maximum depth), at pectoral fin base $7.0 \mathrm{~mm}$ (4.4 in sl and 1.5 in corresponding depth), at end of dorsal fin base $3.5 \mathrm{~mm}$ (8.8 in sl and 2.0 in corresponding depth); head length $12.6 \mathrm{~mm}$ ( $2.5 \mathrm{in} \mathrm{sl})$; snout length $5.1 \mathrm{~mm}(2.5 \mathrm{in}$ $\mathrm{hl})$; interocular distance $5.6 \mathrm{~mm}(2.3 \mathrm{in} \mathrm{hl})$; eye horizontal diameter $3.9 \mathrm{~mm}(3.2 \mathrm{in} \mathrm{hl})$, distance from dorsal profile $0.6 \mathrm{~mm}$ ( $21 \mathrm{in} \mathrm{hl})$; nasal organ length $0.7 \mathrm{~mm}(18 \mathrm{in} \mathrm{hl})$, distance from tip of snout $2.4 \mathrm{~mm}$ (5.3 in $\mathrm{hl}$ ), distance from eye 2.1 $\mathrm{mm}(6.0 \mathrm{in} \mathrm{hl}$ and 1.1 in distance from tip of snout); mouth width $2.2 \mathrm{~mm}$ (5.7 in $\mathrm{hl})$.

Material examined. -

MHNL 3907 ex parte; 1 specimen, sl 31 mm, lectotype; South Vietnam: surroundings of Thu dau mot River; coll. G. Tirant, 1897.

\section{Description of the paralectotypes. -}

General morphology. - Faint groove on interorbital always present; body spines always distinct; otherwise like general description.

Colour in alcohol. - Like lectotype or even worse preserved; caudal fin colour pattern determines all specimens to be males.

Morphometrics. - sl 20-29 (m 25) mm; tl 26-36 (m 31) $\mathrm{mm}$; dorsal fin rays $12-13$ (m 12.3) of which 3-4 (m 3.3) unbranched, longest ray (the 8-9th) 6.0-9.0 (m 7.6) in sl, shortest ray (the 1st) $12.5-19.1$ (m 15.6) in sl, base 5.8-7.7 (m 6.7 ) in sl and $0.7-1.1(\mathrm{~m} 0.9)$ in longest ray; anal fin rays $11-12$ (m 11.4) of which $1-3$ (m 2.5) unbranched, longest ray (the 6-9th) 7.0-9.1 (m 7.9) in sl, shortest ray (the 1st) $13.8-17.3$ (m 15.8) in sl, base 7.7-10.0 (m 9.0) in sl and 0.91.4 (m 1.2) in longest ray; pectoral fin rays $15-16$ (m 15.1), longest ray 7.4-10.7 (m 9.0) in sl, shortest ray (the 1st) $8.3-12.4$ (m 10.7) in sl, base 7.7-11.1 (m 9.0) in sl and 0.8-1.2 (m 1.0) in longest ray; depth maximum $2.5-2.9$ (m 2.7) in sl, at pectoral fin base $2.6-2.9$ (m 2.8) in sl, at end of dorsal fin base 3.9-5.2 (m 4.5) in sl; width maximum $3.5-4.2(\mathrm{~m} \mathrm{3.9)}$ in $\mathrm{sl}$ and $1.2-1.5$ (m 1.4) in maximum depth, at pectoral fin base 3.54.4 (m 3.9) in sl and $1.2-1.5$ (m 1.4) in corresponding depth, at end of dorsal fin base 7.0-9.6 (m 8.3) in sl and 1.6-2.1 (m 1.8) in corresponding depth; head length 2.3-2.6 (m 2.5) in sl; snout length 2.4-2.9 (m 2.6) in hl; eye horizontal diameter 2.4-3.3 (m 2.9) in hl, distance from dorsal profile 8.5-21 (m 12.6) in hl; interocular distance 1.9-2.4 (m 2.2) in hl; nasal organ length 10.915.0 (m 13.0) in hl, distance from tip of snout 4.0 -5.9 (m 4.7) in hl, distance from eye 5.2-7.0 (m 5.9) in $\mathrm{hl}$ and 1.1-1.5 (m 1.3) in distance from tip of snout; mouth width 5.2-5.7 (m 5.5) in $\mathrm{hl}$.

\section{Material examined. -}

MHNL 3907 A-L; 12 specimens, sl 20-29 mm, paralectotypes; South Vietnam: surroundings of Thu dau mot River; coll. G. Tirant, 1897.

MNHN 37-60; 1 specimen, sl $25 \mathrm{~mm}$; paralectotype; South Vietnam: surroundings of Thu dau mot River; coll. Gaillard, MHNL (considered to be the holotype by Le Danois, 1961).

Distribution. - T. lorteti is known from Thailand, Cambodia, South Vietnam and East and West Malaysia. Thus, it is geographically isolated from the other members of the cutcutia-group, $T$. travancorius living in India, Travanoore, T. cutcutia living in East-India, Burma, Ceylon and Bangla Desh.

Etymology. - The name lorteti - originally written Lorteti - was given by Tirant in honour of Dr. L. Lortet, at the time Doyen de la Faculté 
de Médicine de Lyon and Directeur du Muséum de Lyon.

Tetraodon travancorius Hora \& Nair, 1941. Figs. 10-12.

\section{Tetraodon travancorius}

HORA \& NAIR, 1941: 391-393, figs. 3-4 (original description, discussion and figures on variation of colour pattern, discussion on differences with $T$. cutcutia; India: Travancore, Pamba River; material in ZSI, reg. no. F 13601/1, holotype and paratypes) (in subgenus Monotretus).

MENON \& YAZDANI, 1963: 162 (in type list of ZSI; no additional material) (in subgenus Monotretus).

Description of holotype and paratypes (after Hora \& Nair, 1941; no material examined). -

General morphology. - Body oblong, compressed laterally; dorsal profile arched, highest at midst of back; interorbital flat; body spines inconspicuous; skin reticulated finely; origin of anal fin situated beneath anterior third of dorsal fin base; mouth terminal, directed forwards; lower border of eye slightly below level of mouth corner, upper border not interfering with dorsal profile; nasal organ a hollow cylinder, nearly as high as wide, only distalmost part of which is formed into two very small lips which are bent inwards, giving a key-hole appearance to opening of nasal organ.

Colour in alcohol. - Ground colour of upper parts grayish, of lower parts much lighter; usually two black, oval patches on upper lateral surface of body in front of dorsal fin, the patches situated in a much lighter area; posterior of patches a dark, broad band running to caudal fin, partly continuing on central rays; usually a dark spot in the middle of course of band; other dark spots at base of caudal fin and at base of posteriormost two dorsal fin rays; a dark patch above pectoral fin and a spot behind it; back with a narrow, light interocular band, two irregular dark patches posterior to V-shaped marking behind patches, an irregular band in front of dorsal fin and triangular patches in front of or behind dorsal fin; fins plain.

Morphometrics (based on 5 specimens). - sl 15.7 - 17.0 (m 16.5) mm; tl 20.8-22.0 (m 21.4) mm; dorsal fin rays $7-8$ (m 7.8), longest ray $6.5-8.0$ (m 7.3) in sl; anal fin rays 8; pectoral fin rays 16-17 (m 16.8); depth 2.2-2.6 (m 2.4) in sl; head length $2.3-2.5$ (m 2.4) in sl; eye diameter $2.4-2.7$ in $\mathrm{hl}$.
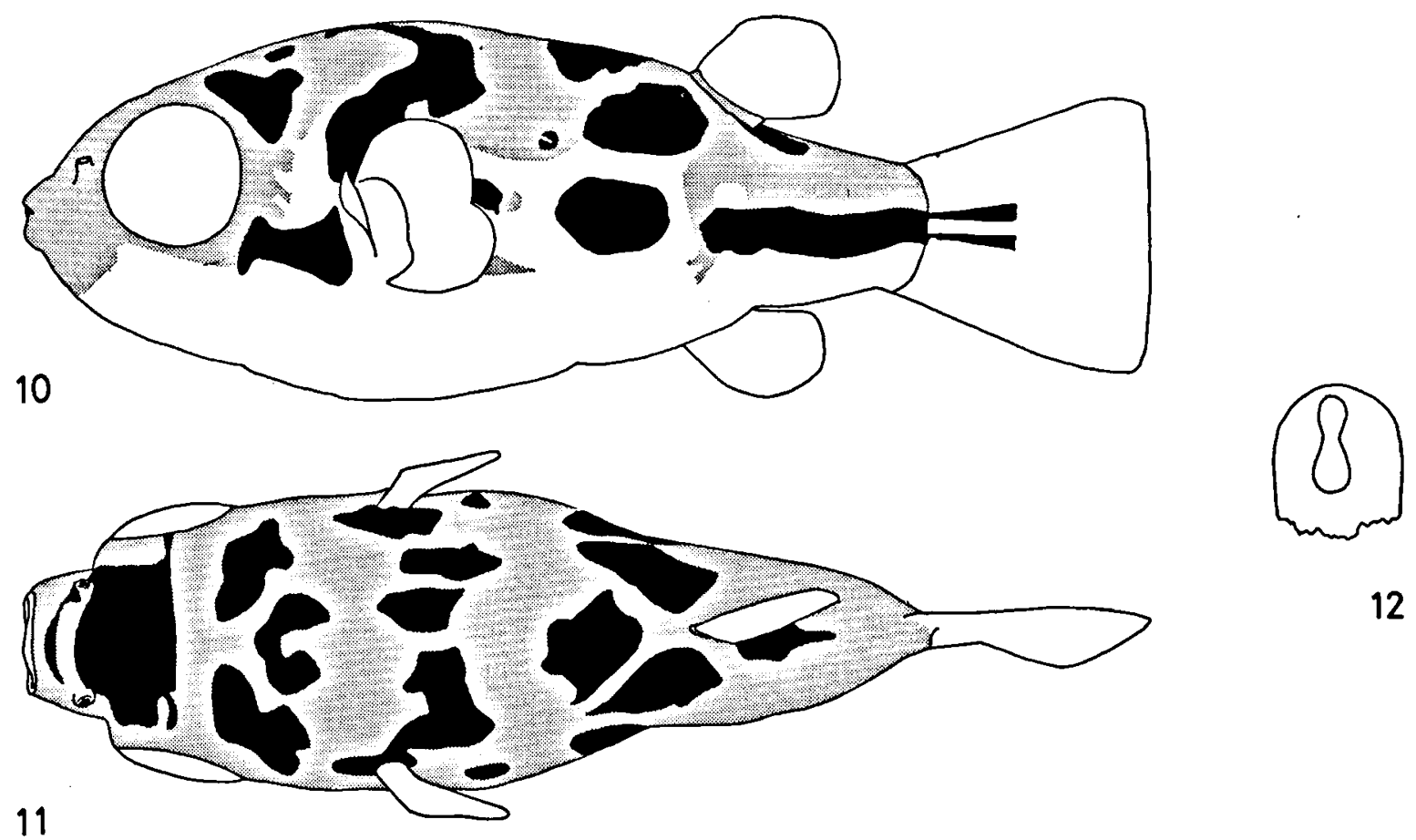

Figs. 10-12. Tetraodon travancorius Hora \& Nair, 1941.

Fig. 10. Lateral view of ZSI F 13601/1, holotype, after Hora \& Nair (1941: fig. 3b).

Fig. 11. Dorsal view of ZSI F 13601/1, holotype, after Hora \& Nair (1941: fig. 3a).

Fig. 12. Nasal organ of ZSI F 13601/1, holotype, after Hora \& Nair (1941: fig. 3c). 
Material examined by Hora \& Nair. -

ZSI F 13601/1; 1 specimen, holotype; India: Travancore, Pamba River; coll. K. B. Nair.

ZSI F 13601/1; 9 specimens, paratypes; India: Travancore, Pamba River; coll. K. B. Nair.

Distribution. - This species has hitherto only been recorded from the type locality: India: Travancore, Pamba River, where it occurs abundantly according to the collector of the type material, K. B. Nair.

Etymology. - The species was named after the type locality, India: Travancore.

\section{le i u r s - g r o u p}

Diagnosis. - Tetraodon species with the nasal organ formed by a hollow cylinder which is distally divided into two lips over one-third to one-half of its length; head depressed; body spines often embedded in a complicatod papillated dermal structure; D 12-15; A 10-12; P 21-24. Three species: T. palembangensis, T. leiurus and $T$. fangi.

Discussion. - The leiurus-group is intermediate between the cutcutia-group, which has the nasal cylinder not or scarcely two-lipped, and the fluviatilis-group with its cylinders often deeply divided into flaps. Differences with the erythrotaeniagroup include the fin ray counts, the form of the dorsal profile, and the colour pattern. The group was considered a single species by Le Danois (1959). Her misuse of the name cutcutia for this species is discussed with the cutcutiagroup.

The oldest names proposed for members of the group are $T$. leiurus Bloeker, 1851, and T. palembangensis, Bleeker, 1852. Both species were figured in Bleeker, 1865a. It should be noted that the figure of $T$. leiurus is drawn from a nontypical specimen, as it shows many round, ocellated spots, while all Bleeker material and other material examined show the dark lateral spots more or less polygonal. Nevertheless, the difference in colour pattern between the two Bleeker-species is striking, $T$. leiurus always possessing many lateral dark spots, leaving only a whitish network, $T$. palembangensis always showing a wide-meshed iaterai network, some of the meshes enclosing dark spots or ocelli. Other differences are a slightly lower dorsal fin ray count, a shorter snout and deeper dermal pits in $T$. palembangensis.

Le Danois (1959) considers T. leiurus merely the male of a sexual dimorphic Monotreta cutcutia palembangensis. She does not give any evidence for this opinion other than the examination of "les types des Bleeker: Arothron palembangensis et Tetraodon leiurus", present in MNHN. According to her type list (1961) these "types" should be MNHN 2310: paratype of $\boldsymbol{A}$. palembangensis, $160 \mathrm{~mm}$; and MNHN 03-184: paratype of $T$. leiurus, $130 \mathrm{~mm}$. As the first species was described originally by Bleeker from a single specimen, tl $210 \mathrm{~mm}$, and the second species from 5 specimens, tl $60-98 \mathrm{~mm}$, the indication by Le Danois is incorrect and her opinion on sexual dimorphism thus has no ground.

In 1902 Vaillant described a new species, close to $T$. palembangensis: $T$. pinguis. After comparing the single central Borneo specimen with a single $T$. palembangensis specimen he found the following discriminating characters: a wider and shorter snout, bigger skin papillae, fins more fatty, fin ray counts D 9; A 9. In examining the holotype of $T$. pinguis I could not find any difference with $23 T$. palembangensis specimens, apart from the fins being indeed more fatty. The snout length even proved to equal exactly the mean value for $T$. palembangensis, viz. 2.8 in hl.

De Beaufort (1962) rejects the opinion of $T$. pinguis being a distinct species. He, however, confirms the original description in stating that there is only one lateral spot on each side, and that there are 9 dorsal fin rays, although they are difficult to count. My own experience indicates that the lateral spots are 4 (left side) plus 3 (right side) and X-ray photographs showed 13 dorsal fin rays, hence normal for $T$. palembangensis.

Le Danois (1961) must be mistaken when claiming two (sic) holotypes of $T$. pinguis for MNHN (reg. no. 91-213, 214) as only one specimen was originally described. Moreover, the type locality is Borneo: Mahakam River, the MNHN specimens originating from Borneo: Kapuas River.

The remaining six names in the group can be ascribed to the closely allied species $T$. leiurus Bleeker, 1851 and $T$. fangi Pellegrin \& Chevey, 1940. The number of synonyms is not surprising, considering the great variability of the colour pattern. Basically this consists of an irregularly coloured back and a great number of rounded or polygonal dark spots on the sides. Variations on this pattern include a light interocular band, 1-3 
dark dorsal patches and the presence of an ocellus ventral to the origin of the dorsal fin. Benl (1957a) and several other authors in aquarium journals found the dorsal colour pattern to vary with mood, and the lateral ocellus to vary with age, at least in T. fangi. Klausewitz (1957a) found geographical variation of the dorsal pattern in the same species. A very striking colour variation is found in the Cambodian type specimens of $T$. cambodgiensis Chabanaud, 1923. Instead of a greyish-tan dorsal ground colour with or without dark patches they show many oval or polygonal whitish spots, leaving a dark network only. This dorsal pattern descends for some length along the sides, which otherwise, at first glance, only are marked by a big ocellus. The dark network, however, could also be found in some specimens among otherwise normally coloured series from Singkarak (Sumatra) and Bogor (Java). One of the Bogor specimens (sl $74 \mathrm{~mm}$ ) gives extreme proof of the unemployability of colour pattern in $T$. leiurus by possessing the characteristic blackspot leiurus-pattern on the left side and parts of the belly and the characteristic white-spot cambodgiensis pattern on the right side and the back.

The value of the lateral ocellus as a systematic character was discussed e.g. by De Beaufort (1962). In this discussion it is stated that the specimens recorded by Hora (1923b, 1924), and a Deli (Sumatra) specimen in ZMA laterally only are marked by an ocellus. This is not true: the specimens show a faint indication of the polygonal dark spots near the ocellus. The same proves to be true for two of the cambodgiensis syntype specimens. When examining 71 specimens from 19 series it became clear that all intermediates occur between absence and presence of the ocellus, the frequency of presence decreasing apparently to the south-west of Borneo.

Having rejected colour pattern as a splitting character in Bleeker's concept of $T$. leiurus, the problem has become clearer. In 1905 Popta contributed two nominal species from Borneo: $T$. bergii and $T$. hilgendorfii. The taxonomic value of both was discussed by De Beaufort (1962). According to Popta $T$. bergii differs from typical leiurus in a different head length, a wider interorbital, a lower position of the eyes and the colour being plain tan above, plain cream below. Examination of the unique specimen shows the head length to be 2.3 in sl (exactly the mean value for $T$. leiurus), the interorbital being $1.8 \mathrm{in} \mathrm{hl}$ (T. leiurus 1.7-2.2), and the position of the eyes being normal. The different colour pattern could be due, as pointed out by De Beaufort, to the same cause which made the skin form pustules on head and body. $T$. hilgendorfii was claimed to be different in having a different head length, a lower and more anteriorly placed eye, and the lateral spots more elongate, descending to the belly. Head length in 5 out of the 6 syntypes proved to be 2.3 in sl, hence normal again. The slight differences in colour pattern cannot be of systematic value, as pointed out before.

T. cambodgiensis Chabanaud, 1923, also can not be retained as a separate species. The author gives as discriminating characters that the body spines are retractile and provided with a fleshy lobe, that the lateral line system encircles the eye, and that the snout length exceods the distance from eye to gill opening. In my experience all these characters apply to $T$. leiurus as well, although not in all specimens. Other characteristics counted and measured by me did not show im. portant differences. Mean values in $4 T$. cambodgiensis syntypes were D 14.0; A 11.0; P 23.8; snout length 2.2 in hl; head length 2.6 in sl. For T. leiurus they are D 13.8; A 11.0; P 23.0; snout length $2.3 \mathrm{in} \mathrm{hl}$; head length 2.5 in sl.

The third species recognized in the leiurusgroup, $T$. fangi, was described by Pellegrin \& Chevey (1940) from Vietnam. Benl (1957a) described the same species from aquarium imported specimens as $T$. leiurus brevirostris, and in the same year Klausewitz (1957a) described it as T. ocellaris. Probably both Benl and Klausewitz overlooked the publication of Pellegrin \& Chevey because in my view there can not be any doubt of the conspecifity of the three nominal species. Pellegrin \& Chevey did not give any differences with $T$. leiurus. They only compared $T$. fangi with T. patoca Hamilton, 1822, a species which can easily be recognized by the different form of the nasal organ.

Klausewitz only gives the presence of the lateral ocellus as a discriminating character. As pointed out above, this can not be an important specific character. The characteristic $T$. fangi oolour pattern also occurs in some typical $T$. leiurus. Benl gives three differences for $T$. fangi: less spinose, a shorter snout, and a greater interorbital width expressed in the distance between the tip of the snout and the interocular band. Spinosity, however, is a doubtful character, as it usually is in the Tetraodontidae in general and in small specimens in particular (as most $T$. fangi specimens are). 


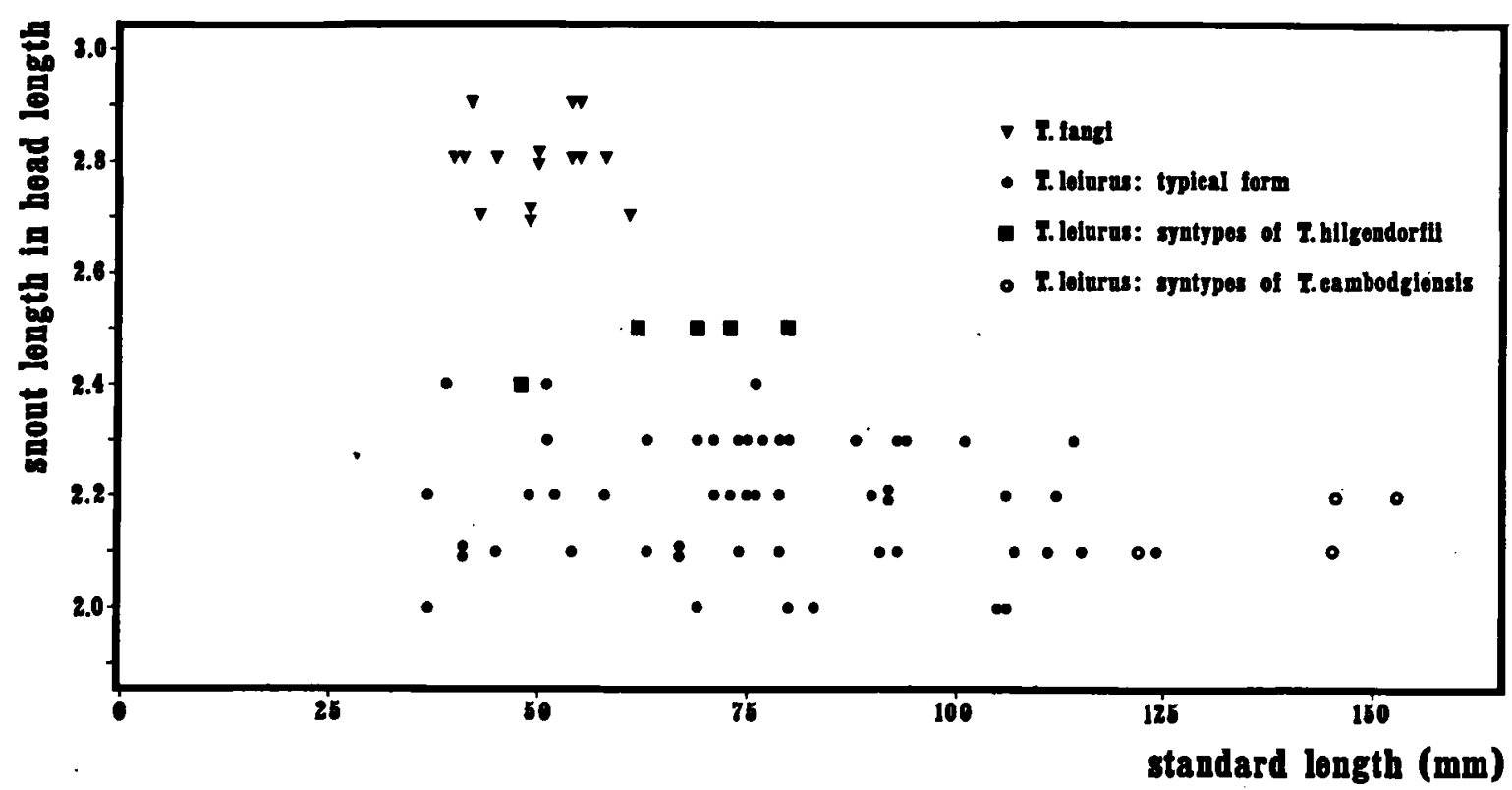

Fig. 13. Relation between relative snout length and standard length in Tetraodon leiurus, showing discontinuity between $T$. fangi and the three other forms and showing independence of relative snout length from standard length (age).

Small specimens always are less spiny than bigger specimens (as most $T$. leiurus specimens are). There is however, a difference in the papillose structure hiding the spines, as this is more elaborate in $\boldsymbol{T}$. fangi (figured in Klausewitz $1957 \mathrm{a})$, but this is only a relative difference. The quotient used by Benl was found by him to be 1.30 and 1.31 in two $T$. fangi specimens compared to $0.90-1.17$ (m 1.03) in 7 leiurus specimens examined. My own measurements yielded ratios of 1.0-1.4 (m 1.15) in $15 T$. fangi specimens and 0.8-1.2 (m 1.01) in $36 \mathrm{~T}$. leiurus specimens, so the difference is not striking.

This leaves only one discriminating character: length and form of the snout. Length of the snout proves to be very constant as can be soen from fig. 13. Snout length ratios given in the literature, which are probably taken with methods different from those employed here, even indicate values up to 3.3 in hl (Fowler, 1937). Fig. 13 also shows that the likely assumption of $T$. fangi being the young of $T$. leiurus is improbable: the relative snout length is independent of age. The short snout and the presence of the ocellus proved constant not only in the specimens examined, but also in the specimens referred to in the aquarium journals.

An argument for giving $T$. fangi a different specific rank instead of a subspecific rank may be found in its geographical distribution. Although only a few exact localities are known (e.g.
Thailand: near Patalung; Vietnam) they suggest that the species could be sympatric with $T$. leiurus (e.g. Thailand: mouth of Patalung River and Patalung Lake; Cambodia).

The picture given above of differences between $T$. leiurus and $T$. fangi is slightly obscured by the syntypic material of $T$. hilgendorfii as their relative snout length is slightly intermediate (see fig. 13). I therefore hesitated whether to consider $T$. hilgendorfii a separate subspecies or to reunite $T$. leiurus and $T$. fangi. The final argument in my considerations was a zoogeographic one: $T$. hilgendorfii was collected in East Borneo, a rich source of biological variability, as was also the case in species of the fluviatilis-group. So, I consider $T$. hilgendorfii a junior synonym of $T$. leiurus. However, for the sake of certainty the material was not incorporated in the descriptions of $T$. leiurus.

Tetraodon palembangensis Bleeker, 1852.

Figs. 14-15.

Tetraödon palembangensis

BLEEKER, 1852a: 21, 25, 26 (original description, discussion on differences with $T$. reticulatus Bleeker, 1849 and T. lineatus Bloch, 1785; Indonesia: Sumatra, Palembang; holotype not recognizable within Bleeker Collection).

BLEEKER, 1852c: 37, 38 (description and discussion after Bleeker, 1852a; no additional material). 
BLEEKER, 1853e: 429, 435, 438 (listed; Indonesia: Borneo, Pontianak; material not recognizable within Bleeker Collection).

Arothron palembangensis;

BLEEKER, 1854b: 22, 28 (listed; Indonesia: Sumatra, Muarakumpe; material not recognizable within Bleeker Collection).

BLEEKER, 1854d: 260 (listed; no additional material).

BLEEKER, 1855a: 9 (listed; no additional material).

BleEKER, 1859g: 340 (listed; Indonesia: Sumatra, Palembang; material not recognizable within Bleeker Collection).

BLEEKER, 1859h: 4, 10 (listed; Indonesia: Sumatra, Musi River system near Palembang; material not recognizable within Bleeker Collection).

? Arothron palembangensis;

BLEEKER, 1857c: 12 (listed; no additional material).

BLEEKER, 1858a: 7, 30, 35 (listed; Indonesia: Sumatra, Palembang; material not recognizable within Bleeker Collection).

BLEEKER, 1859a: 201 (listed; no additional material).

BLEEKER, 1859f: 266 (listed; Indonesia: Sumatra, Djambi River; material not recognizable within Bleeker Collection).

BLEEKER, 1860a: 9, 66 (listed; no additional material).

BLEEKER, 1860c: 5, 7 (listed; Indonesia: Borneo, Sintang; material not recognizable within Bleeker Collection).

BLEEKER, 1860g: 200 (listed; no additional material).

Crayracion palembangensis;

BLEEKER, 1865a: 66, 67, tab. 208 fig. 3 (emendated description, figured, discussion on differences with T. leiurus Bleeker, 1850; no additional localities).

BLEEKER, 1866: 36 (listed; no additional material).

Tetrodon palembangensis;

GüNTHER, 1870: 288 (description; Indo-Malayan Archipelago \& Thailand \& unde; material in BMNH, reg. no. of first series 1867.11 .28 .115 , latter series unregistered) (in subgenus Crayracion).

KÁROLI, 1882: 187 (listed; Thailand; material in MNH, reg. no. 1606) (doubtful reference, material not available for study).

WEBER, 1894: 458 (listed; no material).

Volz, 1903: 413 (listed; Indonesia: Sumatra, Banjuasin River; material probably in NMB).

Volz, 1904: 483 (listed; Indonesia: Sumatra, Inderagiri River system \& Inderagiri River at Prawap \& Sumatra, Wampu-Selapian River; material probably in NMB).

Volz, 1906: 234 (listed; no additional material).

WEBER \& DE BEAUforT, 1912: 541 (listed; Indonesia: Sumatra, Kampar Kiri River at Gunung Sahilan \& Sumatra, Inderagiri River at Taluk; material in ZMA, reg. no. 108.957 and 109.000 respectively).

CHEveY, 1932: 31 (listed; unde; no material) (doubtful reference).

HARDENBERG, 1936: 254 (listed; Indonesia: Borneo, middle course of Kapuas River; material probably lost).

De Beaufort, 1939: 194 (listed; Indonesia: Java Sea, Belitung Island; material in ZMA, reg. no. 108.968) (in subgenus Crayracion).

Tetrodon palembangensis Variété

TIRANT, 1885 (in ed. 1929): 95-96 (description, discussion on differences with typical $T$. palembangensis and on lack of material for comparisons; S. Vietnam: Thu dau mot; material not in MHNL) (in subgenus Crayracion).
Tetraodon palembagensis;

Valllant, 1893a: 36, 61 (listed; Indonesia: Borneo, Kapuas River; material in MNHN, reg. no. 91-213/ 214).

ValllaNT, 1893b: 2 (listed; no additional material).

Tetraodon pinguis

VAILlANT, 1902: 7, 24, 28, 38, 40 (original description, discussion on differences with $T$. palembangensis; Indonesia: Borneo, banks of Mahakam River at Tepu; material in RMNH, reg. no. 7928, holotype).

Tetraodon palembangensis;

Vaillant, 1902: 12, 14, 16, 28, 40 (listed, discussion on differences with $T$. pinguis Vaillant, 1902; Indonesia: Borneo, Kapuas River at Pontianak, at Sintang and at Semitau; material in RMNH, reg. no. 7926-27).

Fowler, 1905: 507 (listed; Indonesia: Borneo, Kapuas River) (doubtful reference).

SMITH, 1945: 576 (description; no additional material).

TWEEDIE, 1952: 89 (description; West Malaysia: Kuala Tahan \& West Malaysia: Tasek Běra; material in NMS, reg. no. 2316, 2317).

DE BEAUfort, 1962: 392-394 (description, discussion on differences with $T$. pinguis Vaillant, 1902 and $T$. palembangensis cf. Hora, 1923 \& 1924; no additional localities) (in subgenus Monotretus).

Tetraodon pelambangensis;

FRASER-BRUNNER, 1943: 14 (listed as representative of genus and subgenus; no additional material) (in suhgenus Monotretus).

Monotreta cutcutia palembangensis;

LE DANoIS, 1959: 20, 152, 154, 156, 157, 246, 247, 251, 254, figs. 84d, 112, 113, 114 (description, lateral view, frontal view, skull and nasal organ figured, discussion on sexual dimorphism, osteology and evolution; material in MNHN, should comprise types of $T$. palembangensis, $T$. leiurus and $T$. pinguis Vaillant, 1902, see holotype description).

LE DANOIS, 1961: 466 (in type list of MNHN, material supposed to be types of $T$.leiurus, $T$. palembangensis and $T$. pinguis Vaillant, 1902, see holotype description).

D'Aubenton \& Blanc, 1966: 557, 558, fig. 3 (description in discussion on $M$. tiranti d'Aubenton \& Blanc, 1966, figured after Bleeker, 1865a; Laos: Luang Prabang; material in MNHN).

\section{General description. -}

General morphology. - Body oblong, anteriorly compressed ventrodorsally; dorsal profile rooflike or arched, highest point between pectorals often bumplike; interorbital concave or flat, often with a median groove; lateral line system very conspicuous; body spines small, hidden under papillae in rounded dermal pits; dermal pits very conspicuous and densely covering back, sides, and belly between nasal organs and anal fin base; spines themselves only conspicuous if body inflated; skin with dermal muscles thick, on belly and often on other parts of body loosely attached; origin of anal fin situated beneath posterior half of dorsal fin base; mouth terminal directed forward; lower 

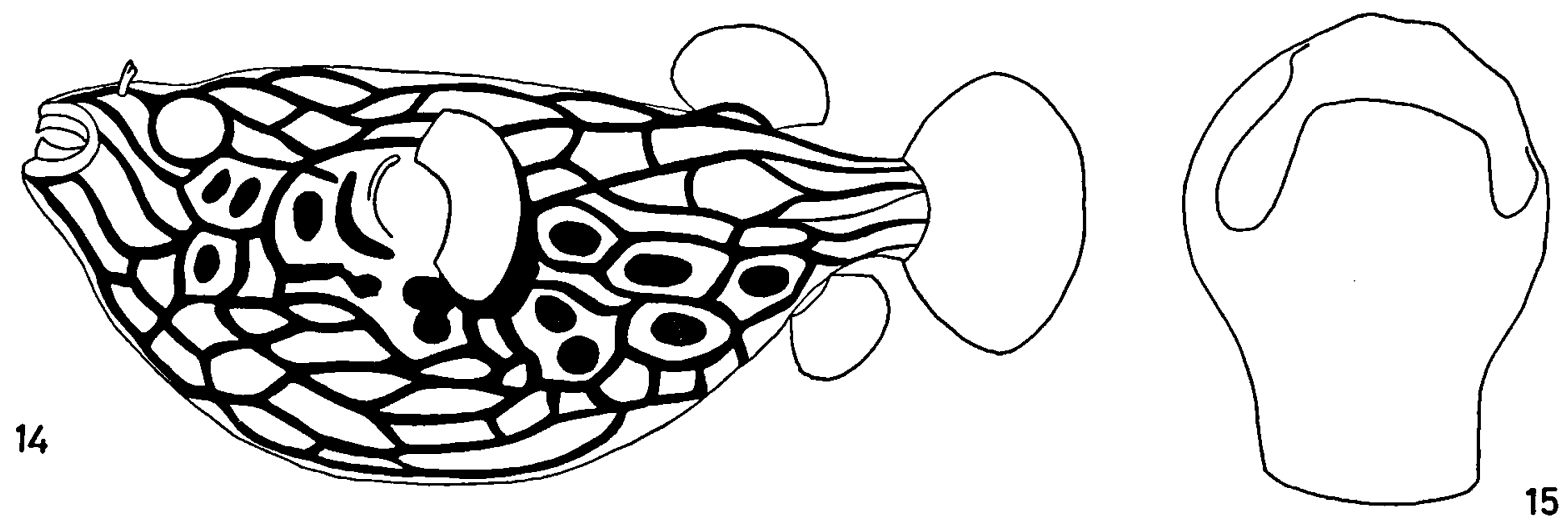

Figs. 14-15. Tetraodon palembangensis Bleeker, 1852.

Fig. 14. Lateral view after Bleeker (1865a: tab. 208, fig. 3).

Fig. 15. Nasal organ of ZMA 101.852, sl $117 \mathrm{~mm}$.

border of eye at or below level of mouth corner, upper border sometimes interfering with dorsal profile; nasal organ a tentacle, less than distal third of which is divided into two narrow lobes; apposed surfaces of lobes smooth.

Colour in alcohol. - Ground colour of upper parts tan, of belly yellowish or greyish white; back with obscure mixture of lighter and darker in which sometimes a light interocular band or a dark triangular patch on posterior part of head can be recognized; sides and belly with a dark meshwork, most distinct and regular on belly; meshwork on sides has been described as light vermiculating lines and streaks; sides with 3-18 rounded spots, darker than meshwork, in meshes if present giving impression of ocelli, diameter 14-106 (m 35) in sl; average diameter of meshes on belly 15 in sl; caudal fin proximally or distally sometimes darker; other fins plain.

Morphometrics (based on 23 specimens). - s1 36-194 (m 119) mm; tl 45-232 (m 141) mm; dorsal fin rays $12-14$ (m 12.7) of which $1-3(\mathrm{~m}$ 1.8) unbranched, longest ray (the 7-10th) 8.3-11.0 (m 9.5) in sl, shortest ray (the 1st) 18-25 (m 21) in sl, base 8.7-12.6 (m 10.7) in $\mathrm{sl}$ and 0.9-1.3 (m 1.1) in longest ray; anal fin rays 10-12 (m 10.9) of which 1.2 (m 1.3) unbranched, longest ray (the 7-8th) 8.7-10.5 (m 9.7) in sl, shortest ray (the 1st) 15-49 (m 23) in sl, base 12.5-17.7 (m 14.1) in sl and 1.2-1.9 (m 1.5) in longest ray; pectoral fin rays 21-23 (m 22.0) of which 1-2 (m 1.7) unbranched, longest ray (the 6-9th) 8.3-11.6 (m 10.0) in sl, shortoxt ray (tho 1st) $20-33$ (m 24) in sl, base 7.1-10.3 (m 8.2) in sl and 0.7-0.9 (m 0.8) in longest ray; depth maximum 2.1-3.5 (m 2.7) in sl, at pectoral fin base 2.3-3.5 (m 2.9) in sl, at end of dorsal fin base 5.8-8.5 (m 6.8) in sl; width maximum 2.13.2 (m 2.5) in sl and 0.7-1.1 (m 0.9) in maximum depth, at pectoral fin base 2.1-2.9 (m 2.6) in sl and 0.7-1.0 (m 0.9) in corresponding depth, at end of dorsal fin base 5.8-9.1 (m 7.6) in sl and 0.8-1.4 (m 1.1) in corresponding depth; head length 1.9-2.2 (m 2.1) in sl; snout length 2.7-3.1 (m 2.8) in hl; interocular distance 1.7-2.5 (m 2.1) in $\mathrm{hl}$; eye horizontal diameter 4.5-9.3 (m 6.3) in $\mathrm{hl}$; nasal organ length $12.4-31$ (m 18.3) in hl, distance from tip of snout 3.3-5.7 (m 3.9) in hl, distance from eye 8.0-11.8 (m 9.8) in hl and 1.84.5 (m 2.6) in distance from tip of snout; mouth width 2.9-4.6 (m 3.6) in hl; upper lip depth 9.818.0 (m 13.8) in hl; lower lip depth 12.2-40 (m 21) in $\mathrm{hl}$.

Material examined. -

BMNH 1867.11.28: 115; 1 specimen, sl $167 \mathrm{~mm}$; IndoMalayan Archipelago; Bleeker Collection.

BMNH 1887.2.28: 3-4; 2 specimens, sl 177-182 mm;

Malaysia: Malaya, Perak; coll. J. Anderson.

BMNH 1922.5.19: 114; 1 specimen, sl 194 mm;

Malaysia: Malaya, Jahan River; coll. Kloss.

BMNH no reg. no.; 1 specimen, sl $79 \mathrm{~mm}$; unde; coll. College of Surgeons.

NMB 5176; 1 specimen, sl $147 \mathrm{~mm}$; Thailand: Thale Luang; coll. H. Bernatzik, 1937.

RMNH 7341; 5 specimens, tl $150-220 \mathrm{~mm}$; IndoMalayan Archipelago; Bleeker Collection.

RMNH 7926-27 in part; 1 specimen; Indonesia: Borneo, Pontianak; coll. Moret, 1895.

RMNH 7926-27 in part; 2 specimens; Indonesia: Borneo, Sintang; coll. J. Büttikofer, 1894.

RMNH 7926-27 in part; 4 specimens; Indonesia: Borneo, Kapuas River at Semitau; coll. J. Büttikofer, 14-XII-1893.

RMNH 7928; 1 specimen, sl $182 \mathrm{~mm}$; Indonesia: Borneo, banks of Mahakam River at Tepu; 4th coll. A. W. Nieuwenhuis, 1896-1897 (holotype of $T$. pinguis Vaillant, 1902).

ZMA 101.852; 2 specimens, sl 117-122 mm; Indonesia: Sumatra, Palembang; coll. Salm, 16-XI-1908. 
ZMA 108.956; 1 specimen, sl $150 \mathrm{~mm}$; Indo-Malayan Archipelago; Bleeker Collection.

ZMA 108.957; 1 specimen, sl $36 \mathrm{~mm}$; Indonesia: Sumatra, Gunung Sahilan; coll. J. P. Kleiweg de Zwaan, 1907.

ZMA 108.968; 1 specimen, sl 124 mm; Indonesia: Java Sea, Belitung Island; coll. Kuiper, 1937.

ZMA 108.999; 5 specimens, sl 85-137 mm; Indonesia: Sumatra, Djambi River; coll. Moolenburgh, 1909.

ZMA 109.000; 2 specimens, sl 96-102 mm; Indonesia: Sumatra, Inderagiri River at Taluk; coll. J. P. Kleiweg de Zwaan, 1907.

ZMA 110.195; 1 specimen, sl $133 \mathrm{~mm}$; Indonesia: Java, Bay of Djakarta; coll. C. P. Sluiters.

ZMA 110.196; 1 specimen, sl $69 \mathrm{~mm}$; Indonesia: Borneo, Putussibau; coll. H. A. Lorentz, 29-VI-1909.

ZMA 110.197; 1 specimen, sl $79 \mathrm{~mm}$; Indonesia: Borneo, Bunut; coll. H. A. Lorentz, 26-VI-1909.

\section{Description of the holotype. -}

Recognition. - Bleeker based his original description on 1 specimen, tl $210 \mathrm{~mm}$, from Indonesia: Sumatra, Palembang, fresh water. Apparently Bleeker mixed the specimen at a certain time with conspecific material, of which he, according to his Atlas Ichthyologique, in 1865 in total possessed 9 specimens, tl 101-203 mm. After his death the same number of specimens was auctioned in 1879 . They were divided in four lots of $6,1,1$, and 1 specimens, the first of which most probably was bought by RMNH, the second by the precursor of ZMA.

In search of the holotype I could trace 8 specimens of the Bleeker Collection, viz.:

- BMNH 1867.11.28: 115; 1 specimen, tl $197 \mathrm{~mm}$; indicated by Günther as "One of the typical specimens".

- MNHN 2310; 1 specimen, sl $160 \mathrm{~mm}$; indicated by Le Danois, 1961 as "Paratype. Sumatra (Palembang)".

- RMNH 7341; 5 specimens, tl 150, 190, 200, 220, $220 \mathrm{~mm}$.

- ZMA 108.956; 1 specimen, tl $183 \mathrm{~mm}$.

The BMNH specimen most likely is not the holotype as it was bought, according to the reg. no., in or before 1867, when Bleeker still was alive and, as generally is believed, he kept most of his type material in his personal collection. The MNHN specimen can not be the holotype because its sl is too short; besides it can not be a paratype as no paratypes exist in a species described from 1 specimen. This leaves the RMNH and ZMA series. Counting with a possible decrease of $10 \%$ of th the most probable candidates to be the holotype are the 190 and $200 \mathrm{~mm} \mathrm{RMNH}$ specimens.
This view is supported by the fact that the 5 specimens must represent the most numerous lot of the auction, being the A-lot, generally believed to contain the types. There does not, however, exist a way of determining which of the two specimens is the holotype. Moreover, two specimens auctioned in 1879 could not be traced and theoretically one of them might be the holotype.

Given the above facts, the holotype can not be indicated. The International Code of Zoological Nomenclature does not carry a solution for this situation. A lectotype cannot be chosen because there is no syntypical series, while a neotype selection is prohibited by art. 75. Whitehead et al. (1966) nevertheless selected neotypes in comparable cases. In this case I choose not to do so because the 7 Bleeker specimens I examined are very homogeneous, in both morphology and colour pattern, and perfectly match the figure given by Bleeker in his Atlas Ichthyologique, so any of the Bleeker specimens can be used as a safe base for defining the species.

Distribution. $-T$. palembangensis is known from Malaya, Thailand, Laos, and Borneo. The record from Indonesia: Java, Bay of Djakarta seems doubtful, as all other records are from fresh water and the specimen was sent from the Bogor Museum which at the time was not always accurate when labelling.

Etymology. - The name palembangensis refers to the type locality, Sumatra: Palembang, from where the species also was often recorded after the original description.

\section{Tetraodon leiurus sensu lato}

The synonyms and references listed below could apply both to $T$. leiurus and $T$. fangi.

Arothron leiurus

BleEkER, 1861c: 101, 102 (listed; Thailand: Chao Phaya River; no material, just seen in sketchbook of De Castelnau).

BLEEKER, 1865c: 33 (listed; Thailand; material probably in MNHN).

Tetraodon leiurus;

BLEEKER, 1864: 353 (listed after Bleeker, 1861c; no material).

VaIllant, 1902: 20, 21, 28 (listed; Indonesia: Borneo, Upper Kapuas River system, mouth of Raun River \& Upper Kapuas River system, Mandai River \& Borneo, Middle Mahakam River, Tepu; material in RMNH, reg. no. 7929-31). 
SuvatTI, 1936: 165 (listed; Thailand: Klong River at Ban Pong \& Thailand: Phayau Lake, Chieng-rai \& Thailand: Tale Sap, Songkhla \& Thailand, Sikuk River \& Thailand: Chao Phaya River system, Hang Kraben; material probably in BFB).

TwEedIE, 1940: 81 (listed; West Malaysia: Jelai River; material in NMS, reg. no. 2318).

Fraser-BrunNer, 1943: 14 (listed as representative of genus and subgenus; no additional material) (in subgenus Monotretus).

SMITH, 1945: 577 (description, discussion on differences with T. leiurus cf. Hora, 1923b and 1924; no additional material).

TWEEDIE, 1952: 88-89 (listed; West Malaysia: Jelai River \& West Malaysia: Kuala Tahan; material in NMS, reg. no. 2318, 2319, 2320).

Crayracion leiurus;

BLEEKER, 1865a: 68 (ex parte) (in discussion on distribution; after Bleeker, 1861c).

Tetrodon liurus;

KÁROLI, 1882: 187 (listed; West Malaysia: Singapore \& Indonesia: Borneo, Sanatbung; material in $\mathrm{MNH}$, reg. no. 1608,1609 , not available for study).

Volz, 1904: 483 (listed; Indonesia: Sumatra, Upper Langkat, Wampu River).

Volz, 1906: 233 (listed; no additional material).

POPTA, 1906: 215, 218, 221, 232, 263 (description of skin disease; Indonesia: Upper Kapuas River system, Bongan River; material in RMNH, reg. no. 7656).

Tetrodon leiurus;

FOWLER, 1934a: 101 (listed; Thailand: Chiengmai; material probably in ANSP).

FoWLER, 1938: 237 (listed after Károli, 1882; no additional material).

Monotreta cutcutia cutcutia;

LE DANOIS, 1959: 154-156, 246, 247, fig. 109-111 (description; lateral view, frontal view and skull figured; discussion on osteology, sexual dimorphism and evolution; material in MNHN, including type material of $T$. cambodgiensis Chabanaud, 1923 and T. fangi).

LE DANOIS, 1961: 466, 467 (listed in type catalogue of MNHN as valid name for $T$. leiurus, $T$. cambodgiensis, and $T$. fangi; material in MNHN, reg. no. 03-184, $1922-80 / 83$, and $40-42$, the first abusively indicated as paratype, see syntype description of $T$. leiurus).

D'Aubenton \& Blanc, 1966: 555, 558, 560, fig. 4 (description, figured, discussion on differences with T. cambodgiensis Chabanaud, 1923; Cambodia: Tonle Sap; material in MNHN, reg. no. 66-53/54).

Tetraodon leiurus Bleeker, 1851.

Figs. 16-20.

\section{Tetraödon leiurus}

BLEEKER, 1851e: 97 (original description; Indonesia: Java, Djakarta, sea and river mouths; material in part in RMNH, reg. no. 7342 ex parte, see syntypes description).

BLEEKER, 1852a: 18 (listed, discussion on differences with T. kappa Russell, 1803 and T. sans tache Lacépède, 1798; no additional material).

BleEKER, 1852d: 410, 415, 440, 441 (emendated description; Indonesia: Borneo, Kusan River at Prabukarta \&
Indonesia: Java, Djakarta \& Indonesia: Sumatra, Solok; material probably at least in part in RMNH, reg. no. 26477 , see syntypes description).

BLEEKER, 1853e: 435, 438 (listed; no additional material). Arothron leiurus;

BLEEKER, 1854b: 22, 28 (listed; Indonesia: Sumatra, Padang; material not recognizable within Bleeker Collection).

BLEEKER, 1854d: 260 (listed; no additional material).

BLEEKER, 1855a: 9 (listed; no additional material).

BLEEKER, 1855c: 260 (listed; Indonesia: Sumatra, Lahat; material not recognizable within Bleeker Collection).

BLEEKER, 1857c: 12 (listed; no additional material).

BLEEKER, 1858a: 30, 35 (listed; no additional material).

BLEEKER, 1858c: 86, 87 (listed; Indonesia: Java, Bogor \& Java, Preanger; material not recognizable within Bleeker Collection).

BLEEKER, 1859a: 201 (listed; no additional material).

BLEEKER, 1859e: 48 (listed; Indonesia: Java, Bogor; material not recognizable within Bleeker Collection).

Bleeker, 1859g: 340 (listed; Indonesia: Sumatra, Palembang; material not recognizable within Bleeker Collection).

BLEEKER, 1860a: 9, 66 (listed; no additional material).

BLEEKER, 1860c: 7 (listed; no additional material).

BLEEKER, 1860e: 1 (listed; Indonesia: Sumatra, Lematang River near Lahat; material not recognizable within Bleeker Collection).

BLEEKER, 1865d: 172 (listed; no additional material).

BLEEKER, 1866: 36 (listed; no additional material).

Crayracion leiurus:

BleEKer, 1865a: 66, 67, tab. 213 fig. 1 (description, discussion on differences with $T$. palembangensis and T. fluviatilis; no additional localities).

Tetrodon liurus;

GÜNTHER, 1870: 288 (description; Indonesia; material in BMNH, reg. no. 1867.11.28: 110, indicated as "One of the typical specimens") (in subgenus Crayracion).

WeBER, 1894: 429, 458 (listed; Indonesia: Sumatra, Singkarak Lake \& Java, Bogor; material in ZMA, reg. no. 108.951 and 108.967 , respectively).

Tetrodon Hilgendorfii

POPTA, 1905: 185, 186 (original description; Indonesia: Borneo, Upper Mahakam River system, Boh River; material in RMNH, reg. no. 7658 , holotype and paratypes).

POPTA, 1906: 211, 215, 221, 232, 263, 265, 296, pl. 10 fig. 43 (emendated description, discussion on differences with $T$. leiurus; no additional material).

Tetrodon Bergii

POPTA, 1905: 186 (original description; Indonesia: Borneo, Upper Kapuas River system, Bongan River, Bulit; material in RMNH, reg. no. 7657 , holotype).

POPTA, 1906: 215-218, 221, 232, 263, 296, pl. 10 fig. 44 (emendated description, discussion on differences with T. leiurus; no additional material).

Tetrodon cambodgiensis

Chabanaud, 1923: 137-140 (original description, discussion on differences with $T$. palembangensis, $T$. pinguis Vaillant, 1902 and $T$. leiurus; Cambodia: Phnom Penh; material in MNHN, reg. no. 1922-80/83, syntypes) (in subgenus Crayracion).

Chabanaud, 1924: 581 (publication not seen).

Chevey, 1936: 45 (listed; Cambodia: Tonle Sap; no material).

Chevey \& Le Poulain, 1940: 22, 78 (listed; Cambodia; 
no material) (in subgenus Crayracion).

Tetraodon liurus;

HORA, 1923b: 184 (description, discussion on differences with T. leiurus cf. Günther, 1870; Thailand: Nontaburi; material in ZSI, reg. no. F 10613/1).

HorA, 1924: 500, text-fig. 10 (specimen defined as similar to Hora 1923b; Thailand: mouth of Patalung River near Lampam; material in ZSI, ex parte reg. no. F 10472/1).

Tetrodon leiurus;

HARDENBERG, 1935: 239 (listed; Indonesia: Borneo, mouth of Mahakam River near Samarinda; material probably lost).

Tetraodon palembangensis;

SUVATTI, 1936: 166 (listed; Thailand: Upper Bangpakong River \& Thailand: Thale Noi; material at least in part in BMNH, reg. no. 1897.10.8: 148-149 ?).

Tetraodon leiurus;

BENL, 1956: 4, 6, 10, Abb. 5 (description, aquarium data; no additional material).

De BEAUFORT, 1962: 392, 394, 395 (description, discussion on differences with $T$. leiurus cf. Hora, 1923b and 1924, T. hilgendorfii Popta, 1905, T. bergii Popta, 1905 and T. leiurus brevirostris Benl, 1957; Indonesia: Sumatra, Deli \& Indonesia: Borneo, Serawai River; material in ZMA, reg. no. 101.891 and 108.959 respectively) (in subgenus Monotretus).

\section{General description. -}

General morphology. - Body oblong, head region depressed; dorsal profile arched or flattened, highest at midst of back; interorbital flat or convex, often with a median groove; lateral line system often distinct; spines small, densely set, sometimes in part hidden under papillae, covering back, sides and belly between nostrils and anus; origin of anal fin beneath posterior half of dorsal fin base; mouth terminal, directed forwards or upwards; lower border of eye above level of mouth corner, upper border not interfering with dorsal profile; nasal organ a tentacle, distal 1/3-1/2 of which is divided into two flattened lobes; apposed surfaces of lobes smooth.

Colour in alcohol. - Ground colour of upper parts tan, of lower parts yellowish white; sides with many polygonal or rounded dark spots (diameter $14-\infty$ in sl) leaving mostly only a lighter network of ground colour; sometimes one of these spots, situated beneath origin of dorsal fin at middle of side, markedly bigger and darker than adjacent spots, which are arranged circularly around it, eventually as a distinct ocellus (horizontal diameter at least 11.8 in sl); colour of back variable, often with a light interorbital band, bordered posteriorly by a dark trapezoid patch reaching to midst of back or beyond; sometimes a second dorsal dark patch just before dorsal fin; sometimes back pattern of many oval or whitish spots (average diameter 20 in sl), this pattern sumetimes descending on sides; upper part of snout irregularly dark; chin and belly uniformly yellowish white; fins plain, caudal often darkest.

Morphometrics (based on 57 specimens). - sl 30-153 (m 80) mm; tl 38-175 (m 101) mm; dorsal fin rays $13-15$ (m 14.1) of which $1-3(\mathrm{~m}$ 2.0) unbranched, longest ray (the 7-10th) 6.4-9.3 (m 7.9) in sl, shortest ray (the 1st) $13.1-26$ (m $18.4)$ in sl, base 7.3-10.7 (m 9.2) in sl and 1.0-1.5 (m 1.1) in longest ray; anal fin rays $10-12$ (m 11.0) of which $1-2(\mathrm{~m} 1.1)$ unbranched, longest ray (the 6-9th) 6.8-10.0 (m 8.2) in sl, shortest ray (the 1st) $12.9-26(\mathrm{~m} \mathrm{18.5)}$ in sl, base $10.6-15.8(\mathrm{~m}$ 12.6) in sl and $1.3-2.1$ (m 1.6) in longest ray; pectoral fin rays $21-24$ (m 22.9) of which $1-2$ (m 1.9) unbranched, longest ray (the 5-8th) 7.711.3 (m 8.9) in sl, shortest ray (the $1 \mathrm{st}) 21-76$ (m 33) in sl, base 7.2-10.1 (m 8.6) in sl and 0.8 $-1.2(\mathrm{~m} 0.9)$ in longest ray; depth maximum $2.2-$ 3.8 (m 3.1) in sl, at pectoral fin base 2.5-4.1 (m 3.4) in sl, at end of dorsal fin base 5.0-7.6 (m 6.4) in sl, width maximum $2.4-3.9$ (m 3.0) in sl and $0.8-1.1$ (m 1.0) in maximum depth, at pectoral fin base $2.4-3.8$ (m 3.0) in sl and $0.8-1.1$ (m 1.0) in corresponding depth, at end of dorsal fin base 5.2-9.5 (m 6.8) in sl and 0.9-1.1 (m 1.1) in corresponding depth; head length $2.1-2.5$ (m 2.3) in sl; snout length $2.0-2.4$ (m 2.2) in hl; interocular distance $1.7-2.2$ (m 2.0) in hl; eye horizontal diameter 4.7-7.9 (m 5.8) in hl, distance from dorsal profile 13.5-61 (m 27) in hl; nasal organ length 11.7-30 (m 20) in hl, distance from tip of snout 2.6-3.7 (m 3.1) in hl, distance from eye 6.3-13.9 (m 8.7) in $\mathrm{hl}$ and 1.9-5.0 (m 2.6) in distance from tip of snout; mouth width 3.0 5.3 (m 4.3) in hl; upper lip depth 7.3-21 (m 11.8) in hl; lower lip depth 12.9-29 (m 18.1) in hl.

\section{Material examined. -}

BMNH 1867.11.28: 110; 1 specimen, sl 91 mm; Indonesia; Bleeker Collection; indicated by Günther, 1870 as "One of the typical specimens", see description of the syntypes.

BMNH 1897.10.8: 148-149; 2 specimens, sl 92-124 mm; Thailand: Upper Bangpakong River; coll. S. S. Flower, III-1897; ex RSM.

BMNH 1922.5.19: 110-112; 3 specimens, sl 41-67 mm; West Malaysia: Jahan River; coll. Kloss.

BMNH 1922.5.19: 113; 1 specimen, sl $63 \mathrm{~mm}$; West Malaysia: Sembeling River; coll. Kloss.

MNHN 1922-80/83; 4 specimens, sl 122-153 mm; Cambodia: Phnom Penh; coll. La Résidence Française, 1915 and/or coll. A. Krempf, 1921 (syntypes of T. cambodgiensis Chabanaud, 1923). 

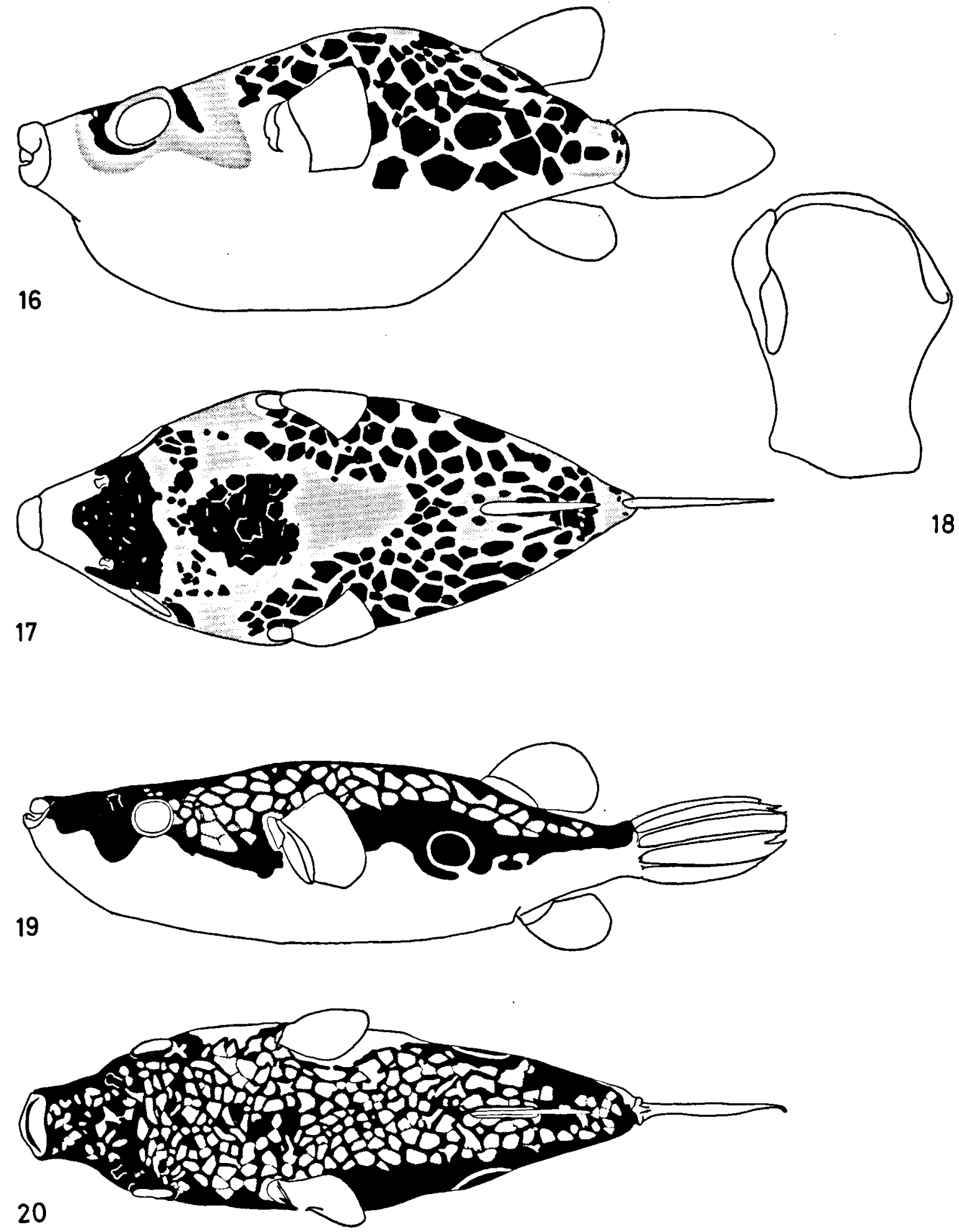

Figs. 16-20. Tetraodon leiurus Bleeker, 1851.

Fig. 16. Lateral view of ZMA 108.951 , sl $96 \mathrm{~mm}$.

Fig. 17. Dorsal view of ZMA 108.951, sl $96 \mathrm{~mm}$.

Fig. 18. Nasal organ of MNHN 22-80, syntype of T. cambodgiensis Chabanaud, 1923, sl $153 \mathrm{~mm}$.

Fig. 19. Lateral view of MNHN 22-80, syntype of T. cambodgiensis Chabanaud, 1923, sl $153 \mathrm{~mm}$.

Fig. 20. Dorsal view of MNHN 22-80, syntype of T. cambodgiensis Chabanaud, 1923, sl $153 \mathrm{~mm}$. 
NMB 5174-5175; 2 specimens, sl 93-106 mm; Thailand: Thale Luang; coll. H. Bernatzik, 1937.

RMNH 7342; 14 specimens, sl 30-105 mm; Indonesia; Bleeker Collection; probably containing 4 out of the 5 syntypes, see syntypes description. (10 non-typical specimens now catalogued RMNH 26477).

RMNH 7657; 1 specimen, sl 65 mm; Indonesia: Borneo, Upper Kapuas River system, Bongan River, Bulit; coll. A. W. Nieuwenhuis, VII-1898 (holotype of T. bergii Popta, 1905).

RMNH 7658; 6 specimens, sl $48-80 \mathrm{~mm}$; Indonesia: Borneo, upper Mahakam River system, Boh River; coll. A. W. Nieuwenhuis, V/VIII-1900; (holotype and paratypes of T. hilgendorfii Popta, 1905) (morphometrics not used in general description).

ZMA 101.886; 1 specimen, sl $69 \mathrm{~mm}$; Indonesia: Sumatra, Pangian River; coll. E. Jacobson, III-1914.

ZMA 101.891; 1 specimen, sl $111 \mathrm{~mm}$; Indonesia: Sumatra, Deli, coast; coll. L. P. de Cosquino de Bussy, 1908/09.

ZMA 102.308; 1 specimen, sl $67 \mathrm{~mm}$; Indonesia; Bleeker Collection; possibly completing the syntypes series in

RMNH 7342 (see description of the syntypes).

ZMA 108.951; 10 specimens, sl 37-114 mm; Indonesia:

Sumatra, Sinkarak Lake; coll. M. Weber, 1888.

ZMA 108.959; 4 specimens, sl $64-83 \mathrm{~mm}$; Indonesia:

Borneo, Serawai River, Lebang Hara; coll. Witkamp.

ZMA 108.967; 11 specimens, sl 71-93 mm; Indonesia:

Java, Bogor; coll. M. Weber, 1888.

ZSI F 10472/1; 1 specimen, sl $115 \mathrm{~mm}$; Thailand: mouth of Patalung River near Lampam; coll. N. Annandale.

ZSI F 10613/1; 1 specimen, sl $51 \mathrm{~mm}$; Thailand: Nontaburi; coll. M. Smith.

\section{Description of the syntypes. -}

Recognition. $-T$. leiurus was originally described by Bleeker from 5 specimens, tl $60-98 \mathrm{~mm}$. The emendated description a year later was based on 11 specimens, th $60-115 \mathrm{~mm}$. In 1865 , according to the Atlas Ichthyologique, Bleeker possessed 19 specimens, tl $46-130 \mathrm{~mm}$. The catalogue of the auction in 1879 indicates the same total number, divided into lots of $15,1,1,1,1$ specimens. The syntypes, as usual, are not labelled as such and had to be refound within the Bleeker Collection.

In search of Bleeker Collection specimens the following series were traced:

- RMNH 7342; 14 specimens, tl 38-129 mm (10 nontypical specimens now catalogued RMNH 26477).

- BMNH 1867.11.28: 110; 1 specimen, tl $111 \mathrm{~mm}$; indicated by Günther as "One of the typical specimens".

- MNHN 03-184; 1 specimen, sl $130 \mathrm{~mm}$; Indonesia: Central Borneo; ex RMNH; indicated by Le Danois (1961) as "paratype".

- ZMA 102.308; 1 specimen, tl $82 \mathrm{~mm}$.

The RMNH series undoubtedly represents the greater part of the 15 specimens auction lot, with or without one or more of the $1,1,1,1$ specimen lots. Out of these 14 specimens 4 could without much doubt be recognized as syntypes on the basis of the characteristics given by Bleeker, 1851e and 1852d: flabbyness, colourlessness, indistinctness of the lateral line and a matching actual tl: $59-97 \mathrm{~mm}$. The remaining 10 specimens most probably do not contain the missing syntype as none of them shows the same characteristic colour as the other 4 specimens. Probably the 10 specimens form, in part, the material on which Bleeker based his emendated description, their actual maximum tl $(129 \mathrm{~mm})$ being too high and their actual minimum tl (38 $\mathrm{mm}$ ) being too low for considering all of them to belong to the series used for the emendated diagnosis.

It must be noted that both the indications "paratype" and "Central Borneo" as given to the MNHN specimens must be incorrect for a specimen of a species which was described from syntypic material collected in Java. These indications were the major ground on which Le Danois (1959) based her opinion that $T$. leiurus is the male of $T$. palembangensis.

I did not consider it opportune to select a lectotype, since the syntypic specimens were already colourless and flabby in Bleeker's time and the species in fact is based on the emendated diagnosis which incorporates material possessing the discriminating colour pattern. Science can not be served by selecting a lectotype out of 4 badly preserved syntypic specimens and selection of specimens from the emendated diagnosis is prohibited by the International Code of Zoological Nomenclature.

General morphology. - Specimens in poor state of preservation, flabby; spines small, not papillated, retracted, covering area between nasal organs and end of dorsal fin base; eyes high on head, not interfering with dorsal profile; lateral line system inconspicuous; otherwise like general description.

Colour in alcohol. - Completely disappeared, as it was already at time of original description. Material probably used for emendated diagnosis (see material examined) shows colouration in 6 out of 10 specimens, viz. lateral rounded dark spots (in all 6 specimens), a lateral ocellus (in 3 specimens) and two dorsal blotches, on nape and before dorsal fin (in 1 specimen).

Morphometrics (based on 4 specimens). - sl 49. $79 \mathrm{~mm}$; tl $59-97 \mathrm{~mm}$; dorsal fin rays $13-14$ (m 13.8) of which 2.3 (m 2.3) unbranched, longest 
ray 6.4-7.5 (m 9.4) in sl, base 8.8-9.8 (m 9.4) in sl and 1.2-1.5 (m 1.4) in longest ray; anal fin rays i.10, longest ray 7.2-8.3 (m 7.6) in sl, base 11.314.5 ( $\mathrm{m} \mathrm{13.0)}$ in sl and 1.6-1.8 (m 1.7) in longest ray; pectoral fin rays ii.21, longest ray 7.9-8.8 (m 8.3) in sl, base 7.9-8.8 (m 8.4) in sl and 1.0 in longest ray; depth maximum 3.0-3.4 (m 3.2) in sl; width maximum 3.2-3.9 (m 3.6) in sl and 0.81.1 (m 1.0) in maximum depth; head length 2.4 -2.5 (m 2.5) in sl; snout length 2.2-2.5 (m 2.3) in $\mathrm{hl}$; interocular distance 1.8-2.2 (m 2.0) in hl; nasal organ distance from tip of snout 2.6-3.4 (m 3.1) in hl, distance from eye 6.3-9.1 (m 7.7) in hl and 2.6 in distance from tip of snout.

Material examined. -

RMNH 7342 ex parte; 4 specimens, sl 59-79 mm; syntypes; Indonesia: Java, Djakarta; Bleeker Collection.

Distribution. - T. leiurus is known from Thailand, East and West Malaysia, Sumatra, Java, Borneo and Cambodia.

Etymology. - The name leiurus is derived from the greek "leios", meaning "smooth". The name is incorrect in this regard, for some $T$. leiurus specimens show distinct spines; in general these spines are smaller than those of fluviatilisgroup specimens.

Tetraodon fangi Pellegrin \& Chevey, 1940.

Figs. 21-23.

\section{Tetrodon fangi}

Pellegrin \& Chevey, 1940: 157, 158, fig. 2 (original description, discussion on differences with $T$. patoca Hamilton, 1822; South Vietnam: Xano Canal, Vithanh; material in MNHN, reg. no. 40-42, holotype) (in subgenus Leiodon).

Tetrodon leiurus;

FowLER, 1937: 264, figs. 299, 300 (description, lateral view of body and dorsal view of head figured; Thailand: Pitsanulok; material in ANSP).

Tetraodon leiurus brevirostris

BENL, 1957a: 63-65, Abb. 1, 2, 3 (original description, aquarium data, discussion on differences with $T$. leiurus cf. Bleeker, 1851, T. cutcutia and $T$. palembangensis $=T$. steindachneri nom. nov.; probably Thailand, live imported; material in $\mathrm{BMNH}$, reg. no. 1956.1.7.1, holotype, and 1956.1.7.2, paratype).

GEISER, 1958: 100-101 (aquarium data; no additional material).

MERCKENS, 1959: 170, 171, fig. p. 170 (description, aquarium data, discussion on differences with " $T$. palembangensis" $=T$. steindachneri nom. nov.; no additional material).

STERBA, 1959: 638, Taf. 273 (description, aquarium data; no additional material).

\section{Tetraodon ocellaris}

KlauSEWITZ, 1957a: 201, 202, Abb. 4, 5 (original description, discussion on differences with $T$. leiurus and $T$. cutcutia; Thailand: near Patalung \& Thailand: near Krung Thep; material in SMF, reg. no. 3975, holotype, and $3976 \& 3827$, paratypes).

Tetraodon leiurus;

JOHNSEN, 1964: 262 (description in accordance with $T$. leiurus cf. Hora, 1923b and 1924, and in disaccordance with T. leiurus cf. Fowler, 1938 and cf. Inger \& Chin, 1962; Thailand: Kwhae Noi at Ban Kao \& Kwhae Noi at Sai Yok).

Tetraodon cutcutia;

AXELROD et al., 1967: F-579.00, fig. p. F-579.00 (description, aquarium data; no material).

General description. -

General morphology. - Body oblong, greatest part compressed dorsoventrally; dorsal profile arched, highest at midst of back; interorbital convex, without a groove; lateral line system distinct; body spines small, soft, covering back, sides and belly between nostrils and anus, hidden under white papillae; papillae giving smooth impression, especially on belly arranged in netlike pattern; origin of anal fin situated beneath anterior half of dorsal fin base; mouth terminal, directed forwards; lower border of eye slightly above level of mouth corner, upper border higher than lowest point of interorbital, sometimes even interfering with dorsal profile; nasal organ a tentacle, distal 1/3 - 1/2 of which is divided into two flattened lobes; apposed surfaces of nasal lobes smooth.

Colour in alcohol. - Ground colour of upper parts tan, of belly yellowish white; whole of sides and lateral parts of back covered with many polygonal dark spots (diameter 20- $\omega$ in sl), leaving only a lighter network of ground colour; back in part with same spots, in part uniformly tan; a light band between eyes, posteriorly often bordered by a dark trapezoid patch reaching to level of pectoral fins or beyond; sometimes a second, smaller dark patch just anterior of dorsal fin; snout dorsally with dark spots or uniformly dark; chin dark; a big ocellus (horizontal diameter 6.4-11.1 in sl) on sides, horizontally on level with pectoral fin, vertically on level with origin of dorsal fin, nucleus darker than lateral spots; often a light small central spot in nucleus; ocellus with light ring, surrounded by circularly arranged, and partly fused polygonal spots; densely set spinal papillae contribute to general colour pattern; belly laterally with dark spots, more oblong than lateral spots, centrally uniformly yellowish white; fins plain, caudal darkest. 


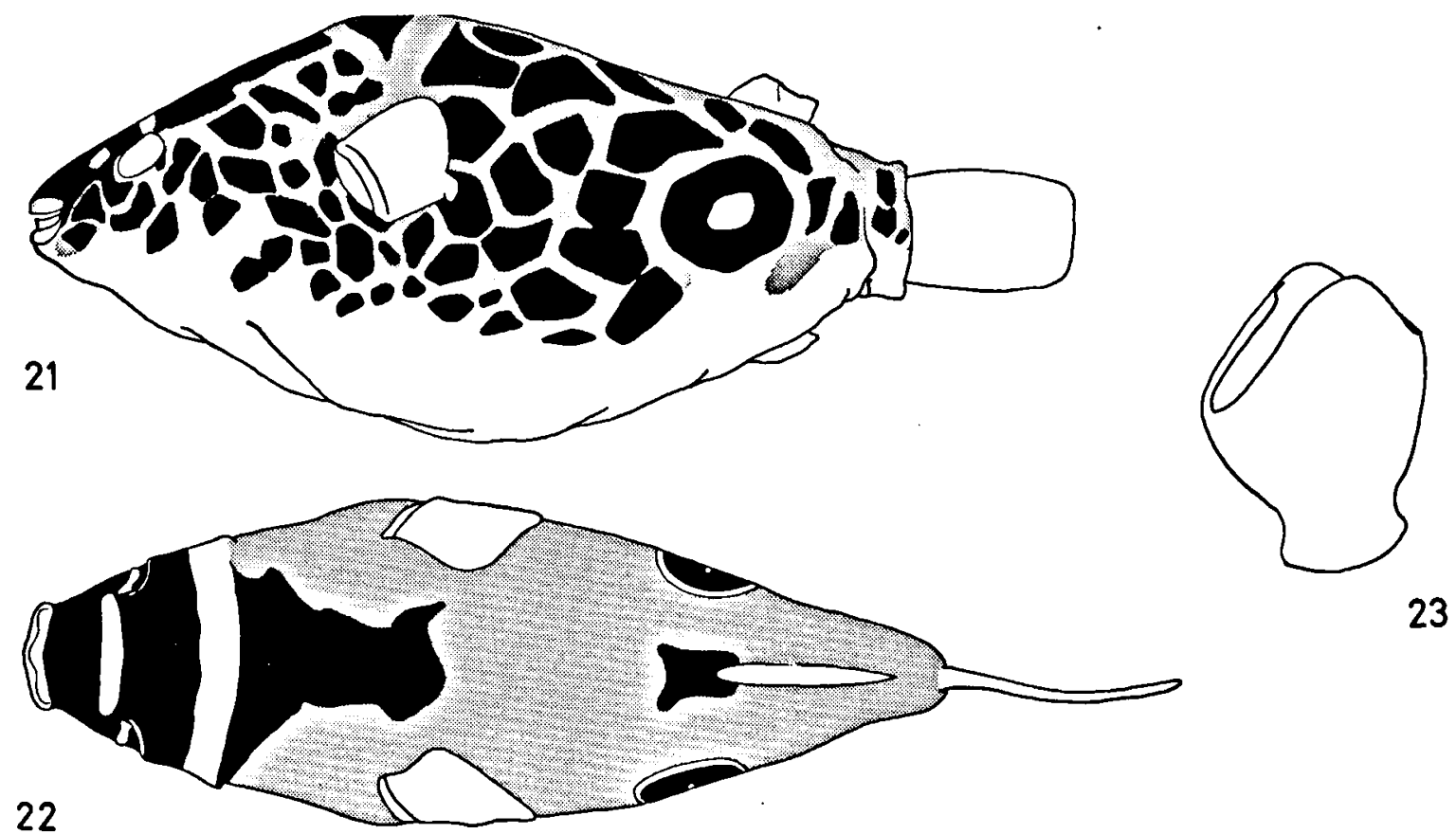

Figs. 21-23. Tetraodon fangi Pellegrin \& Chevey, 1940.

Fig. 21. Lateral view of MNHN 40-42, holotype, sl $55 \mathrm{~mm}$.

Fig. 22. Dorsal view of SMF 3975, holotype of T. ocellaris Klausewitz, 1957, s1 $48 \mathrm{~mm}$.

Fig. 23. Nasal organ of MNHN 40-42, holotype, sl $55 \mathrm{~mm}$.

Morphometrics (based on 15 specimens). - sl 40-61 (m 50) mm; tl 49-74 (m 61) mm; dorsal fin rays $12-14$ (m 13.2) of which 1-2 (m 1.8) unbranched, longest ray (the 8th) 7.7-10.5 (m 8.5) in sl, shortest ray (the 1st) $20-22$ (m 21) in sl, base 7.9-10.2 (m 9.1) in sl and 0.8-1.1 (m 1.0) in longest ray; anal fin rays 10-11 (m 10.8) of which 1.2 (m 1.3) unbranched, longest ray (the 7-8th) 6.5-10.7 (m 8.0) in sl, shortest ray (the 1st) 13.517.0 (m 15.3) in sl, base 11.0-15.3 (m 12.4) in sl and 1.1-2.2 (m 1.8) in longest ray; pectoral fin rays 21-23 (m 22.0) of which 2 unbranched, longest ray (the 5-6th) 7.7-10.4 (m 8.4) in sl, shortest ray (the 1st) $14.0-18.5$ (m 16.6) in sl, base 7.810.4 (m 8.3) in sl and 0.9-1.1 (m 1.0) in longest ray; depth maximum $2.5-4.0$ (m 3.3) in sl, at pectoral fin base 2.7-4.0 (m 3.3), at end of dorsal fin base 4.5-8.1 (m 6.4) in sl; width maximum 2.6-3.4 (m 2.9) in sl and 0.8-1.1 (m 0.9) in maximum depth, at pectoral fin base 2.5-3.4 (m 3.0) in sl and 0.9-1.0 (m 0.9) in corresponding depth, at end of dorsal fin base 5.4-8.4 (m 7.0) in sl and 0.9-1.4 (m 1.1) in corresponding depth; head length 2.1-2.6 (m 2.2) in sl; snout length 2.72.9 (m 2.8) in $\mathrm{hl}$; interocular distance 1.6-2.0 (m 1.8) in hl; eye horizontal diameter 3.7-5.6 (m 4.4) in hl; nasal organ length 11.0-16.7 (m 13.5) in hl, distance from tip of snout 3.1-4.6 (m 3.9) in $\mathrm{hl}$, distance from eye 8.2-12.5 (m 10.2) in $\mathrm{hl}$ and 2.1-3.8 (m 2.6) in distance from tip of snout; mouth width 3.2-4.0 (m 3.4) in hl; upper lip depth 9.6-23 (m 13.9) in hl; lower lip depth 8.8-23 (m 16.0) in hl.

\section{Material examined. -}

BMNH 1957.1.7: 1-2; 2 specimens, sl 54-55 mm; probably Thailand; imported alive through dealer in Zürich; coll. G. Benl (holotype and paratype of $T$. leiurus brevirostris Benl, 1956).

MNHN 40-42; 1 specimen, sl $55 \mathrm{~mm}$; see holotype description.

SMF 3975; 1 specimen, sl $48 \mathrm{~mm}$; Thailand: near Patalung; coll. E. Roloff, 21-IX-1956 (holotype of $T$. ocellaris Klausewitz, 1957).

SMF 3976; 1 specimen, sl $58 \mathrm{~mm}$; Thailand: near Patalung; coll. E. Roloff, 21-IX-1956 (paratype of $T$. ocellaris Klausewitz, 1957).

SMF 3827; 10 specimens, sl $40-61 \mathrm{~mm}$; Thailand: near Krung Thep; coll. E. Schmidt, 24-IV-1956 (paratypes of T. ocellaris Klausewitz, 1957).

Description of the holotype. -

General morphology. - Like general description. Specimen in poor state of preservation, deteriorated, skinny, flabby; lateral line system indistinct for the larger part; whole of body densely papillose.

Colour in alcohol. - Like general description. Horizontal diameter of ocellular nucleus 8.5 and 
$8.5 \mathrm{~mm}$ (6.4 and 6.4 in s); horizontal diameter of central white spot in nucleus 3.5 and $4.5 \mathrm{~mm}$ (15.7 and 12.2 in sl); two dorsal patches present, but too faint for taking measurements; median belly uniformly yellowish, laterally with some dark spots.

Morphometrics. - sl $55 \mathrm{~mm}$; tl $67 \mathrm{~mm}$; dorsal fin rays ii.10; anal fin rays ii.10; pectoral fin rays i-ii.20, longest ray $7.1 \mathrm{~mm}$ (7.7 in sl), base $6.4 \mathrm{~mm}$ ( 8.6 in sl and 1.1 in longest ray); depth maximum $22 \mathrm{~mm}(2.5 \mathrm{in} \mathrm{sl})$, at pectoral fin base $20 \mathrm{~mm}$ (2.8 in sl); width maximum $20 \mathrm{~mm}$ (2.8 in sl and 1.1 in maximum depth), at pectoral fin base 20 $\mathrm{mm}$ (2.8 in sl and 1.0 in corresponding depth); head length $25 \mathrm{~mm}$ (2.2 in sl); snout length 8.8 $\mathrm{mm}(2.8 \mathrm{in} \mathrm{hl})$; interocular distance $13.3 \mathrm{~mm}(1.9$ in $\mathrm{hl})$; eye horizontal diameter $4.5 \mathrm{~mm}$ (5.6 in $\mathrm{hl})$, distance from dorsal profile $0.6 \mathrm{~mm}$ ( 42 in $\mathrm{hl}$ ); nasal organ distance from tip of snout $6.3 \mathrm{~mm}$ (4.0 in $\mathrm{hl})$, distance from eye $2.0 \mathrm{~mm}(12.5 \mathrm{in} \mathrm{hl}$ and 3.2 in distance from tip of snout); mouth width $7.5 \mathrm{~mm}$ ( $3.3 \mathrm{in} \mathrm{hl})$; upper lip depth $2.0 \mathrm{~mm}$ (12.5 in hl); lower lip depth $2.6 \mathrm{~mm}$ (9.6 in hl).

Material examined. -

MNHN 40-42; 1 specimen, holotype, sl $55 \mathrm{~mm}$; South Vietnam: Xano Canal, Vi-thanh; coll. IOI.

Distribution. - T. fangi is only known with certainty from the localities cited in this paper, viz. Thailand (Krung Thep, Ban Kao, Sai Yok, Patalung) and Vietnam (Vi-thanh).

Etymology. - Pellegrin \& Chevey named the species after M. P. W. Fang, specialist on Chinese fishes.

\section{erythrotaenia-group}

Diagnosis. - Tetraodon species with the nasal organ formed by a hollow cylinder which is distally divided, over one-third to one-half of its length, into two rounded or triangular lips; head slightly or not depressed; body spines not papillose; D 9-11; A 8-9; P 18-19. One species: T. erythrotaenia.

Discussion. - Although T. erythrotaenia resembles the members of the leiurus-group, $T$. kretamensis and $T$. steindachneri considering the nasal organ, it is held to constitute a group on its own on the basis of its extremely low fin ray counts, its colour pattern, and its distributional pattern. Fin ray counts in the leiurus-group are D 12-15; A 10-12; P 21-24; in T. kretamensis D 11-13; A 10-10; P 18-19 and in T. steindachneri D 13-15; A 11-13; P 18-21. The colour pattern of $T$. erythrotaenia is unique within the genus in having a plain dark back without further markings. Zoogeographically the species is unique in living east of the Wallace Line.

It must be noted, as was done earlier by Weber (1911) and De Beaufort (1962), that Bleeker's diagnosis in the Atlas Ichthyologique (1865a) is incorrect: the "papilla nasali" are not "apice compressa" but "apice bifida" as was correctly stated in the original description (1853d).

The only species resembling $T$. erythrotaenia in the low fin ray counts are T. travancorius and T. kretamensis. T. travancorius has even lower counts: D 7-8; A 8; P 16-17 but differs unmistakably in possessing the nasal organ characteristic of the cutcutia-group, being only slightly lipped at most. The latter species resembles erythrotaenia also in the other main characteristics: colour pattern and distributional pattern, living just at the east side of the Wallace Line and being the only other Tetraodon possessing a lateral longitu. dinal dark bar. Moreover, T. kretamensis like $T$. erythrotaenia is small, not known to exceed sl $64 \mathrm{~mm}$. Differences in the characters mentioned above however are greater than they seem to be. The difference in mean value for dorsal fin rays is 1.7, for anal fin rays 1.0. Zoogeographically the narrow Makassar Strait separating the two species is a main barrier between two regions. The apparant resemblance in colour pattern neither is basic since the lateral bar does not occur in all specimens of $T$. kretamensis, and Inger, although having seen living specimens of his species, does not mention the second red band which is present in most $T$. erythrotaenia specimens. Moreover, the absence of any special marking on the dorsal surface in $T$. erythrotaenia seems to be a more fundamental difference, as it is a unique character, never occurring in $T$. kretamensis or any other Tetraodon species.

McCulloch (1922) and De Beaufort (1962) pointed out that the species described by Kner (1867) as Crayracion erythrotaenia is not the present species, probably being referable to Sphoeroides pleurogramma (Regan, 1902). Kner appears to have been followed by Ogilby (1886), who in turn was followed by Waite (1904).

Bleeker (1865a) identified specimens in a jar in MNHN labelled Epipedorhynchus Gernaerti as $T$. 
erythrotaenia. This identification most probably is wrong: the jar was said to be from China and no reliable record of true Tetraodon from China is known (neglecting a doubtful locality "China" for $T$. nigroviridis, NMW 64.297). Moreover Le Danois (1959) lists E. Gernaerti as a junior synonym of Geneion honckenii (Bloch, 1787), so the jar should have contained specimens with doublepierced nasal organs different from those in $\mathbf{T e}$ traodon.

Tetraodon erythrotaenia Bleeker, 1853.

Figs. 24-25.

\section{Tetraödon erijthrotaenia}

BLEEKER, 1853c: 318, 319 (listed; Indonesia: Ambon Island; for material see syntypes description).

BLEEKER, 1853d: 155 (listed; Indonesia: Celebes, Maros; for material see syntypes description).

Tetraödon erythrotaenia

BLEEKER, 1853c: 328 (listed after 1853c: 319).

BLEEKER, 1853d: 154, 162, 174 (original description; Indonesia: Celebes, Maros \& Indonesia: Ambon Island; for material see syntypes description) (in subgenus Arothron).

Arothron erythrotaenia;

BLEEKER, 1854c: 477 (listed; no additional material).

BLEEKER, 1854d: 237, 260 (listed; no additional material).

BLEEKER, 1855b: 300 (listed; no additional material).

BLEEKER, 1855e: 402 (listed; Indonesia: Ambon Island; material not recognizable within Bleeker Collection).

BLEEKER, 1856a: 22 (listed; no additional material).

BLEEKER, 1856b: 28 (listed; no additional material).

BLEEKER, 1857a: 28 (listed; no additional material).

BLEEKER, 1857b: 20 (listed; no additional material).

BLEEKER, 1859a: 200 (listed; no additional material).

BLEEKER, 1860d: 12 (listed; no additional material).

Crayracion erythrotaenia;

BLEEKER, 1865a: 67-69, pl. 214, fig. 4 (description, in key, discussion on differences with Epipedorhynchus gernaerti Bibron; no additional material).

BLEEKER, 1865b: 271 (listed; no additional material).

BLEEKER, 1866: 36 (listed; no additional material).

BLEEKER, 1868a: 19 (listed; Indonesia: Moluccas, Gebe Island; material not recognizable within Bleeker Collection).

Tetrodon erythrotaenia;

GÜNTHER, 1870: 298 (description; Indonesia: Ambon Island; material in BMNH) (in subgenus Arothron).

WEBER, 1894: 432, 434, 443, 458 (listed; Indonesia: Ambon Island).

WEBER, 1895: 261 (listed; no material).

WEBER, 1911: 9, 11, 12, 14, 15, 48-49, Taf. 2 fig. 1 I-VII (description, discussion and figures on colour pattern variation, discussion on differences with descriptions by Bleeker and Günther; Indonesia: Kai Besar Island, near Warka \& Indonesia: Wokam Island, Waskai River \& Indonesia: Kobroör Island, Kololobo River near Seltutti \& Kobroör Island, source of Rubanratu River \& Indonesia: Aru Islands, Tenuaborri River, mouth \& Aru Islands, Bendjia River; material in part in ZMA, reg. no. 108.960).

WEBER, 1913: 603-604, 606, 610 (description, discussion on differences with colour pattern of specimens cf. Weber, 1911; Indonesia: New Guinea, Lorentz River at lower course and at Sabang; material in ZMA, reg. no. 108.962 and 101.917 , respectively).

FOWLER, 1928: 471 (description after Günther, 1870; no material).

WHITLEY, 1957: 38 (in type list of AMS; a cotype claimed for AMS, reg. no. B 7629).

Tetraodon erythrotaenia;

De BeAufort, 1913: 152, 159 (listed; Indonesia: Ambon Island, Mirdika River; material in ZMA, reg. no. 108.964).

FrASER-BRUNNER, 1943: 14 (listed as representative of genus and subgenus; no additional material) (in subgenus Monotretus).

BENL, 1956: 144, 172, 202, Abb. 7 (description, aquarium data; no material).

MERCKENS, 1958: 54 (description, aquarium data; no material).

STERBA, 1959: 637, Abb. 604 (description, aquarium data: no material).

DE BEAUFORT, 1962: 392, 397 (description, discussion on colour variation in living specimens; no additional localities) (in subgenus Monotretus).

Monotretus erythrotaenia;

MUNRO, 1958: 294 (listed; no material).

MUNRO, 1967: 552 (in key; no material).

\section{General description. -}

General morphology. - Body oblong, anterior part slightly compressed dorsoventrally, posterior part slightly compressed laterally; dorsal profile arched, highest at midst of back or behind; interorbital convex, without a groove; lateral line system indistinct; spines short, slender, in skinny specimens distinctly two-rooted, scantly distributed on back sides and belly between midst of eyes and origin of dorsal fin; origin of anal fin situated anterior of dorsal fin or beneath anterior third of dorsal fin base; mouth terminal, directed forwards; lower border of eye at level of mouth corner or below, upper border not interfering with dorsal profile; nasal organ a tentacle, distal half or less of which is divided into two flattened, triangular or rounded lobes; apposed surfaces of lobes smooth.

Colour in alcohol. - Ground colour of upper parts tan or dark grey, of belly whitish, grey or almost black; both colours usually separated by a whitish band (red in life) from snout or head to caudal peduncle, this band on head often broken up in dots or vertical lines; white band often bordered inferiorly by a second, dark band; upper surface plain dark, sometimes with a light interocular band; ventral surface whitish, grey or almost black, in the latter cases often marked with whitish 

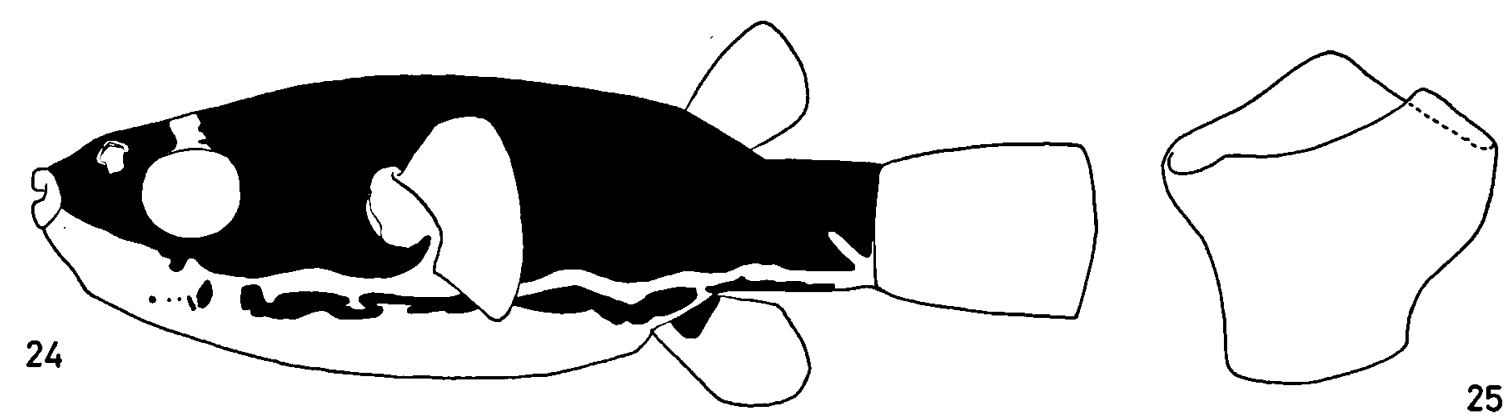

Figs. 24-25. Tetraodon erythrotaenia Bleeker, 1853.

Fig. 24. Lateral view of ZMA 108.962, sl $51 \mathrm{~mm}$.

Fig. 25. Nasal organ of ZMA 108.962, sl $51 \mathrm{~mm}$.

broken lines and whitish dots; fins plain, caudal fin often darkest.

Morphometrics (based on 27 specimens). - sl 2855 (m 41) mm; tl 36-69 (m 52) mm; dorsal fin rays 9-11 (m 10.1) of which $2-3$ (m 2.2) unbranched, longest ray (the 6-8th) 5.6-7.2 (m 6.6) in sl, shortest ray (the 1st) $15.7-23$ (m 19.4) in sl, base 8.8-12.0 (m 10.7) in sl and 1.3-1.9 (m 1.6) in longest ray; anal fin rays 8-9 (m 9.0) of which 1-2 (m 1.6) unbranched, longest ray (the 5-7th) 5.9-8.0 (m 6.8) in sl, shortest ray (the 1st) 12.525 (m 18.1) in sl, base 10.2-12.9 (m 11.5) in sl and 1.4-1.9 (m 1.7) in longest ray; pectoral fin rays $18-19$ (m 18.3) of which $1-3$ (m 2.0) unbranched, longest ray (the 5-6th) $5.9-8.3$ (m 7.2) in sl, shortest ray (the 1st) $14.1-29$ (m 19.5) in sl, base 7.6-9.7 (m 8.6) in sl and 1.1-1.3 (m 1.2) in longest ray; depth maximum 2.7-3.8 (m 3.2) in sl, at pectoral fin base $2.7-3.8(\mathrm{~m} \mathrm{3.3})$ in sl, at end of dorsal fin base 5.1-7.0 (m 6.1) in sl; width maximum 2.4-3.2 (m 2.9) in sl and 0.8-1.0 (m 0.9) in maximum depth, at pectoral fin base $2.4-3.2$ (m 2.9) in sl and 0.8-1.0 (m 0.9) in corresponding depth, at end of dorsal fin base 6.1-8.7 (m 7.3) in sl and 1.1- 1.3 (m 1.2) in corresponding depth; head length $2.3-2.5$ (m 2.4) in sl; snout length 2.3-2.8 (m 2.6) in hl; interocular distance 1.51.8 (m 1.7) in hl; eye horizontal diameter $2.7-4.2$ (m 3.4) in hl, distance from dorsal profile 11.7-27 (m 19.5) in hl; nasal organ length 8.3-14.0 (m 11.0 ) in $\mathrm{hl}$, distance from tip of snout $3.1-4.2$ (m 3.6) in hl, distance from eye 7.7-13.8 (m 10.1) in $\mathrm{hl}$ and $2.1-4.1$ (m 2.8) in distance from tip of snout; mouth width $3.2-4.2$ (m 3.7) in hl; upper lip depth 12.5-25.0 (m 16.4) in hl; lower lip depth 12.2-26 (m 17.6) in hl.

Material examined. -

RMNH 7356; 3 specimens, sl $41-48 \mathrm{~mm}$; Indonesia;
Bleeker Collection (containing type material, see lectotype description) (not incorporated in morphometrics due to bad state of preservation).

ZMA 101.917; 1 specimen, sl $31 \mathrm{~mm}$; Indonesia: New Guinea, Lorentz River at Sabang; coll. H. A. Lorentz, 13/24-VI-1907.

ZMA 108.960; 9 specimens, sl 28-52 mm; Indonesia: Aru Islands, Bendjia River; coll. H. A. Lorentz, 4-XII1907.

ZMA 108.962; 8 specimens, sl $30-51 \mathrm{~mm}$; Indonesia: New Guinea, lower course of Lorentz River at ebbing; coll. H. A. Lorentz, 4-V-1907.

ZMA 108.964; 9 specimens, sl $41-55 \mathrm{~mm}$; Indonesia: Moluccas, Ambon Island, Mirdika River; coll. L. F. de Beaufort, II-1910.

\section{Description of the lectotype. -}

Designation. - Bleeker based his original description on 2 specimens, th $54-58 \mathrm{~mm}$, one from Indonesia: Celebes, Maros and one from Indonesia: Moluccas, Ambon. In the publication containing the original description a third locality, Indonesia: Ceram, is referred to (Bleeker, 1853d: 155) but the material of this locality is not mentioned in the description, nor is it mentioned in any other article by Bleeker. On the contrary, Bleeker states in $1865 \mathrm{a}$ explicitly that $T$. erythrotaenia is only known from Maros and Ambon (aside from a supposed Chinese specimen in MNHN), so most probably the Ceram locality was due to a mistake by Bleeker or his printer and there are only two syntypes. The Atlas Ichthyologique in 1865 mentions 3 specimens, tl $41.58 \mathrm{~mm}$ (a third specimen was recorded from Ambon in Bleeker, 1855e). The same small number of specimens was auctioned in 1879, in one lot. These auctioned specimens do not necessarily represent the three Atlas specimens as additional material was recorded by Bleeker (1868a) from Indonesia: Gebe Island.

In search for the syntypes I could trace 5 specimens from Bleeker Collection: 
- AMS B 7629; 1 specimen; recorded by Whitley (1957) as "cotype".

- BMNH; 1 specimen, tl $2 \%$ inch $=64 \mathrm{~mm}$; recorded by Günther (1870) as "One of the typical examples".

- RMNH 7356; 3 specimens, actual tl 41, 53, $58 \mathrm{~mm}$.

The AMS specimen most probably is not a very important one as Whitehead et al. (1966: 14) said of the AMS Bleeker material in general: "These are almost certainly specimens from Bleeker's duplicate series". The BMNH specimen surely is too long, as tl only can have diminished during the years. The RMNH series almost certainly is the series auctioned in 1879 and as the series auctioned are generally believed to contain at least most of the type material, the RMNH specimens almost certainly incorporate both syntypes.

It is very tempting to consider the RMNH series on base of the length of the specimens identical with the specimens mentioned in the Atlas Ichthyologique. One has however to reckon with a possible decrease in length of $10 \%$, so the syntypes at present can be $49-54$ and $52-58 \mathrm{~mm}$. The only way to be sure about selecting the lectotype from the syntype series is to designate the specimen with actual tl $53 \mathrm{~mm}$, as is done hereby. The other specimen with actual tl $58 \mathrm{~mm}$ most probably is the paralectotype.

General morphology.- Specimen in poor state of preservation, flabby; lateral line system inconspicuous; spines distinctly two-based (distance between tips of roots ca. $1.1 \mathrm{~mm}$ ), relatively densely covering back, sides and belly from nasal organs to origin of dorsal fin; otherwise like general description.

Colour in alcohol.- Completely disappeared; according to original description by Bleeker (1853d: 174): "colore corpore superne olivaceo-fusco inferne flavo, fascia intermedia duplice maxillo-caudali nigra et rubra, pinnis pectoralibus, dorsali caudalique fusco-violaceis, anali flava."

Morphometrics. - Actual sl $43 \mathrm{~mm}$; actual tl 53 $\mathrm{mm}$; dorsal fin rays ii.7, longest ray $6.0 \mathrm{~mm}(7.2$ in sl), base $3.4 \mathrm{~mm}$ (12.6 in sl and 1.8 in longest ray); anal fin rays i.8, longest ray $4.3 \mathrm{~mm}$ (10.0 in $\mathrm{sl})$, base $2.9 \mathrm{~mm}$ (14.8 in sl and 1.5 in longest ray), pectoral fin rays ii.16, longest ray $4.1 \mathrm{~mm}$ (10.5 in sl), base $3.9 \mathrm{~mm}$ (11.0 in sl and 1.1 in longest ray); head length $18 \mathrm{~mm}$ ( 2.4 in sl); snout length $7 \mathrm{~mm}$ (2.6 in $\mathrm{hl})$; interocular distance 9.5 $\mathrm{mm}$ (1.9 in hl); nasal organ distance from tip of snout $5.2 \mathrm{~mm}(3.5 \mathrm{in} \mathrm{hl})$, distance from eye 1.6 $\mathrm{mm}$ (11.3 in $\mathrm{hl}$ and 3.3 in distance from tip of snout).
Material examined. -

RMNH 7356 ex parte; 1 specimen, $s 143 \mathrm{~mm}$; Indonesia: Celebes, Maros or Indonesia: Moluccas, Ambon Island; Bleeker Collection.

Distribution. - As indicated by the synonyms and references, and the list of material, $T$. erythrotaenia is known from Celebes, Ambon, the Kai Islands, the Aru Islands, Gebe and Western New Guinea.

In the paper containing the original description Bleeker refers to a third locality, Ceram, but this locality is not repeated in the original description, nor in later publications. On the contrary, Bleeker records in $1865 \mathrm{a}$ the species as only occurring on Celebes and Ambon, apart from a Paris series said to be from China. The latter locality is doubtful as a true Tetraodon never again was recorded from China. The locality of Sydney, Australia, given by Kner (1867), Ogilby (1886), and Waite (1904) probably is based on an erroneous determination by Kner, as is pointed out in my discussion on the group.

Etymology: The name erythrotaenia is derived from the greek "erythros" meaning "red" and "tainia" (latin "taenia") meaning "ribbon", referring to the red lateral head-tail band.

\section{fluviatilis-g r o u p}

Diagnosis. - Tetraodon species with the nasal organ formed by a hollow cylinder, which is distally divided in two lobes over one-third to five-sixths of its length; interorbital and dorsal profile of head convex; body spines not papillose; sides with dark rounded spots, variable in number and size, but always one spot at base of dorsal fin and one spot at midst of caudal fin base; back with dark spots tending to form three dark patches; D 11-16; A 10-14; P 18-24. Four species, one subspecies: $T$. kretamensis, $T$. nigroviridis, $T$. fluviatilis fluviatilis, $T$. $f$. sabahensis, $T$. steindachneri nom. nov.

Discussion. - Unlike the other groups, the fluviatilis-group is not homogeneous in the form of its nasal organ. In $T$. kretamensis and $T$. steindachneri the nasal lobes occupy only $1 / 3-2 / 3$ of the organ's length and are smooth; in T. fluviatilis and T. nigroviridis they occupy $1 / 2-5 / 6$ of the length and possess spongy tissue on the apposed surfaces in $50-90 \%$ of specimens $\geqslant 60 \mathrm{~mm}$ sl. Nevertheless I prefer to take the four species together on the basis 
of similarities in colour pattern, all four species in all specimens showing the spots at the base of the dorsal and caudal fins and both $T$. steindachneri and $T$. fluviatilis possessing the dark dorsal patches, which may occur in $T$. kretamensis, and are absent in $T$. nigroviridis.

Most authors after Bleeker, 1865a consider the then known members of the group a single species and consider the great variability in fin ray counts and colour pattern due to geographical variation. I certainly do not exclude the possibility that they are right, but while examining and comparing a relatively great number of series I found discriminating characters not directly correlated with geographical distribution. Very remarkable is the presence of all four species here recognized in Borneo, mostly in variable series. This can be explained by the complicated zoogeographic history of the island. Anyway it is remarkable that $T$. steindachneri is known from Thailand, Malaya and East Borneo, not from Sumatra or Java. Likewise $T$. fluviatilis is known from India, Bangla Desh, Burma and Borneo, and not from the intermediate Malaya, Sumatra, Java, Thailand, Cambodia or Vietnam, the intermediate countries being inhabited by $T$. nigroviridis and $T$. steindachneri.

Of course, one can explain the great variability and the overlapping characters in the group by assuming that speciation within the group is of relatively recent origin. Perhaps a superspecies concept would be very useful, but lack of material and field observations make this impossible at the moment. Within the scope of the present study only three possibilities are open: either consider the group a polymorphic single species, or subdivide it in many subspecies, or recognize the main forms as species.

The first possibility seems incorrect and inconvenient as some constant discriminating characters can be given. The second possibility is unattractive as it would yield more than a dozen subspecies on Borneo alone. So I choose the third possibility, erecting a subspecies only in the case of $T$. fluviatilis, as in this case two closely related populations with some constant discriminating characters are separated by some $3500 \mathrm{~km}$, in which even Bleeker, combing out the Indonesian Isles, could not find comparable specimens.

In an attempt to separate the species of the group on the basis of morphological characters only the dorsal and anal fin ray counts and the head length proved to be of taxonomic value, although the first proved to be valuable only statistically (D 13 and A 11 occurring in some specimens of all species except in $T$. kretamensis : D 11-13; A 10), and the second proved to be valuable only in distinguishing the two subspecies of $T$. fluviatilis. The said morphological discriminating characters proved, however, to be correlated with the colour pattern. Pectoral fin ray variation (18-24) could not be correlated, neither with fish characters nor with geographic distribution, apart from T. kretamensis, showing a variation of 18-19 only.

The first descriptions in the fluviatilis-group are $T$. fluviatilis Hamilton, 1822, and $T$. nigroviridis Marion de Procé, 1822. Both species were described poorly and of neither of the two type material is known. The description of Hamilton, however, was accompanied by excellent illustrations, showing the form with three dark patches on the back and rounded, dark spots on the sides. The type locality is Bengal: Ganges River system.

Marion de Procé did not even leave a drawing. only a short French and Latin diagnosis, which are so hard to obtain that I will give the Latin one in length (1822: 130): "T. corpore loevi; dorso viride splendente, maculis rotundis sicut ad latera. P.18. D.12. A.10. C.8."; type locality: N.E. Coast of Sumatra, freshwater pool. This description is in accordance with the description (1849a) and figure (1865a) of $T$. potamophilus Bleeker and the description of $T$. simulans Cantor, 1849, except for differences in fin ray counts (Bleeker: P 22; D 14; A 12; Cantor: P 19-21; D 12-13; A 10-11). In his Atlas Ichthyologique (1865a) Bleeker, however, gives P 18-22; D 12-14; A 11-12; in his description of $T$. fluviatilis which is based on $T$. potamophilus material. Examination of two syntypes of $T$. simulans and Bleeker Collection specimens of $T$. potamophilus convinced me of their conspecifity with $T$. nigroviridis.

In $1852 \mathrm{a}$ - although noting the differences in dorsal colour pattern and fin ray counts - Bleeker regards the possibility that $T$. potamophilus merely might be a climatological variety of $T$. fluviatilis. In 1865a he lumps all nominal species - T. nigroviridis, $T$. potamophilus and $T$. simulans - under the name of $T$. fluviatilis. In this he was followed uncritically ever since by authors copying the synonymy and references listed by earlier authors. Bleeker's change of mind in 1865a, however, was not based on additional material: he still had no access to Indian material of $T$. fluviatilis cf. Hamilton.

In the present study comparisons were made 
with the following results:

T. fluviatilis fluviatilis (India, Ceylon, Bangla Desh, Burma): D 13-16 (m 14.9); A 11-14 (m13.1); hl 2.4-3.1 (m 2.7) in sl; nasal organ with spongy tissue in $90 \%$ of specimens $>60 \mathrm{~mm} \mathrm{sl}$; dark dorsal patches always present.

T. nigroviridis (Ceylon, Burma, Thailand, Malaysia, Great Sunda Islands, S. Vietnam): D 12-14 (m 13.1); A 10-12 (m 11.4); hl 2.1-2.6 (m 2.4) in sl; nasal organ with spongy tissue in $50 \%$ of specimens $\geqslant 60 \mathrm{~mm} \mathrm{sl}$; dark dorsal patches always absent.

I do consider these differences of sufficient value to re-establish $T$. nigroviridis along with $T$. fluviatilis.

In $1865 \mathrm{a}$ Bleeker, in his synonymy of $T$. fluviatilis, also listed Arothron semimaculatus Rüppell, 1852, a name for which a description never was given. It was only listed in a catalogue of SMF with the annotations "Mare javanicum" and "Unter der Bezeichnung von $T$. fluviatilis H. Buchanan von Leyden erhalten" (Rüppell, 1852: 35). Given the locality it most probably concerns $T$. nigroviridis.

Blyth (1860: 173), in searching for $T$. fluviatilis in the Calcutta fish bazaars, discovered a nominal species "approximating it in appearance": Arothron dorsovittatus, differing mainly in the distribution of the body spines, the absence of dark caudal bars and a less typical dorsal colour pattern. Probably Blyth did not leave type material of his species, as Blyth's types should be - according to Dr. Alfred of NMS (in lit.) - in BMNH, and no specimen of the species could be located there. Judging from the description the nominal species must be the same form as figured by Day, 1878, as T. fluviatilis, which was distinguished by Annandale \& Jenkins (1910) as T. fluviatilis var. A and by Le Danois $(1959,1962)$ as $T$. rangoonensis. $T$. fluviatilis cf. Day and id. cf. Hamilton are distinguished in literature mainly on base of the colour pattern of the back, bearing more vague patches in the form cf. Day. Examination of both colour forms learnt the colour differences not to be related with morphological characters. Moreover, both forms were recorded from the same station (Ganges River Delta: Sattermukhi River) by Annandale \& Jenkins (1910).

For $T$. rangoonensis (originally described in the genus Dichotomycterus) Le Danois gives several discriminating characters. I can not judge the differences with respect to osteology and lateral line system, but $I$ found the given number of fin rays (D 17-18; A 14) to be inaccurate. Examination of the syntypic material yielded fin ray counts D 15-16 (m 15.4); A 12-14 (m 13.2), hence normal for $T$. fluviatilis. The subspecies described in 1962 (Dichotomycterus rangoonensis dorsovittatus) neither showed discriminating characters in the specimen indicated as "type" by Le Danois.

In the introduction to the description of $T$. rangoonensis, Le Danois states that $T$. viridipunctatus Day, 1865, in fact is $T$. fluviatilis cf. Hamilton, without giving evidence supporting her statement. Day's description (1865) and figure (1878), however, show a strikingly differently coloured fish, bearing light spots and bands instead of dark spots and patches.

In 1870 Steindachner described Crayracion fluviatilis var. ocellata. The type material can not be located at the moment, but the description and figures allow identification as the form well known by aquarists under the name of $T$. palembangensis: a small Tetraodon with dark dorsal patches much like in $T$. fluviatilis cf. Hamilton, but ornated on back and sides with many light (yellow in life) broken lines and spots. The aquarists name is based on a wrong determination by Meinken (1956), who most likely was led astray by a doubtful collecting station (Sumatra). A similar wrong determination in scientific literature was made by Fowler (1934b, 1935) and probably followed in part by Smith (1945) and others.

Anyway, after 1956 many specimens were imported by aquarium traders and many references were made in aquarium literature (not cited in length), both sources indicating a maximum sl (ca. $60 \mathrm{~mm}$ ) far below the maximum sl of $T$. fluviatilis, and a very constant presence of the light lines and spots. Examination of material shows these characters even to be constant in the remote populations of Thailand and Borneo. A third discriminating character is the form of the nasal organ: flaps nearly as broad as long, not thickened, not provided with spongy tissue, occupying $1 / 3-2 / 3$ of the nasal organ length; this in contrast with the oblong, mostly thickened, often spongeous nasal flaps of $T$. fluviatilis and $T$. nigroviridis.

It is possible that the species is the same as $T$. biocellatus Tirant, 1885 . One can, however, not be sure about that as the description is very poor, no figures are known, and the type material could not be located (not present in MHNL; not indicated in type list of MNHN). According to Le Danois (1959) it concerns Tetraodon ocellatus Linnaeus, 
1758. This, however, is excluded by the indication in the description of $T$. biocellatus: "deux tentacules solides de chaque côté d'une fosse nasale imperforée"; $T$. ocellatus Linnaeus at present is placed in the genus Sphoeroides (sensu lato) because of the double perforated nasal organs.

It proved necessary to replace the name ocellata given by Steindachner by a new name to prevent confusion with the Linnaean species, as pointed out in the etymology of $T$. steindachneri nom. nov.

The last species recognized in the present group was described by Inger (1953) from North Borneo. This species - T. kretamensis - is mainly discriminated from $T$. fluviatilis by lower fin ray counts (D 11-13, m 11.8; A 10; P 18-19, m 18.4), and by the smooth inner surface of the nasal flaps. The colour pattern in some specimens resembles that of $T$. nigroviridis (mostly regularly rounded dark spots), in other specimens that of $T$. fluviatilis (a dark occipital chevron followed posteriorly by two great mid-dorsal spots), in still other specimens $T$. erythrotaenia (a ventrolateral dark band). Differences with $T$. erythrotaenia are discussed within the erythrotaenia-group, differences with $T$. fluviatilis are indicated above. Relationships with $T$. nigroviridis are less clear, the latter species occurring also in Borneo and showing strong variation there, this variation including circular arrangement of the spots on the upper head region and longitudinal arrangement of ventrolateral spots (tending to formation of a ventrolateral band). Moreover, in Borneo the lowest fin ray counts in $T$. nigroviridis are found. Although Inger does not consider the absence of dark caudal fin crossbars in his species an important character, it must be noted that the original description is not correct in this respect as two paratypes after examination proved to possess these bars, though only faintly. On behalf of the facts described above it could be argued that $T$. kretamensis is merely an isolated variety or subspecies of $\boldsymbol{T}$. nigroviridis. Since this form was already described as a species and no positive evidence is present to alter this rank, it seems wise to keep things as they are.

The North Bornean situation is even more complicated by the presence of a form considered by Inger (1955) to be $T$. fluviatilis. Both in colour pattern and in fin ray counts this form is intermediate between the latter and T. kretamensis. Dorsal patches vary from the pattern typical of the first to the pattern of the latter, fin ray counts being D 13-15 (m 13.8); A 11-12 (m 11.9); P 21-22 (m
21.8). With regard to the colour pattern one might consider the Bornean $T$. fluviatilis the adult form of $T$. kretamensis. This, however, is contradicted by the difference in fin ray counts. To consider the two forms as two subspecies of a single species is unprobable because Inger collected both forms at the same stations in the Pinang River. Differences with the other intermediate form, $T$. nigroviridis, include the fin ray counts, the dorsal colour pattern and the nasal flap inner surface, being spongy in $100 \%$ of the Bornean fluviatilis.

Affinities are closest with the Indian T. fluviatilis, the colour pattern in some specimens being nearly identical, the spongy tissue occurring in nearly the same frequency and the number of caudal crossbars being the same. Main differences are the fin ray counts and head length, the latter in the Bornean form being comprised $2.1-2.3$ (m 2.2) in sl, in the Indian form 2.4-3.1 (m 2.7). Because of the arguments given above, I prefer to give the Bornean form a subspecific rank rather than a specific one and name it $\boldsymbol{T}$. fluviatilis sabahensis.

\section{Tetraodon fluviatilis sensu lato.}

Below synonyms and references are listed which could apply to two or more species of the fluviatilis-group.

\section{Arothron semimaculatus}

RüPPELL, 1852: 35 (listed in catalogue of SMF) (nomen nudum).

Crayracion fluviatilis;

BLEEKER, 1866: 36 (listed; no additional material since Bleeker, 1865a).

BEAN \& WeED, 1912: 611 (listed; Indonesia: Java, Bantam, Welcome Bay).

Tetrodon fluviatilis;

GüNTHER, 1870: 299-300 (description; India \& Ceylon \& Singapore \& Borneo; material in BMNH) (in subgenus Arothron).

KÁROLI, 1882: 187 (listed; Singapore: Selita \& Indonesia: Borneo, Simunju; material in MNH, reg. no. 16141616, not available for study).

VINCIGUERRA, 1890: 232 (listed; Burma: Rangoon; material in MSNG).

WEBER, 1894: 458 (listed; no material).

DUNCKER, 1904: 191 (description; West Malaysia: Kuala Selangor \& West Malaysia: Kuala Langat, Muar River at Bandar Maharani; material in SM, reg. no. 1097, Selangor \& in $\mathrm{ZMH}$, reg. no. 8595-6, Langat).

Volz, 1904: 483 (listed; Indonesia: Sumatra, Lower Langkat, Batang Serangan).

DUNCKER, 1912: 270 (listed; Ceylon; no material mentioned).

HORA, 1923a: 766 (listed; India: Chilka Lake; material in ZSI).

VINCIGUERRA, 1926: 536 (description; East Malaysia: Sarawak; material in MSNG). 
HARDENBERG, 1931: 146 (listed; Indonesia: Sumatra, Rokan River mouth, Si Tsji Senebui).

Delsman \& Hardenberg, 1934: 374, fig. 264 (description, figure after Day, 1878; Indonesia: no material).

HARDENBERG, 1934: 5 (listed after Hardenberg, 1931).

HARDENBERG, 1935: 239 (listed; Indonesia: Borneo, Samarinda, fish market; material in RMNH, reg. no. 15306).

HARDENBERG, 1936: 254 (listed; Indonesia: Borneo, Padangtikar. Bay \& Borneo, Terentang River \& Borneo, Pekadai Bay \& Borneo, Ambawang River mouth \& Borneo, Peniti River; material not in RMNH or ZMA).

HARDENBERG, 1937: 13 (listed; Indonesia: Borneo, Kumai River).

FOWLER, 1938: 236 (listed; no material).

Pellegrin \& FANG, 1940: 123 (description; Laos: Ban Nam Khueng, $30 \mathrm{~km}$ N.W. of Ban Houei Sai; material in MNHN) (in subgenus Crayracion).

WiLleM, 1947: $1-5$, figs. $1-2$ (description and figures of internal anatomy; no material).

BECK, 1950: 240 (description, aquarium data; no material).

LADIGES, 1954: 67, fig. 64 (aquarium data; no material).

Tetraodon fluviatilis;

Sauvage, 1883: 155 (listed; Thailand: Chao Phaya River).

VAILlaNT, 1893a: 36 (listed; no material).

ValllaNT, 1902: 28 (listed; Indonesia: Borneo, Pontianak, Kapuas River mouth; material in RMNH, reg. no. 7932).

JORDAN \& RICHARDSON, 1909: 45 (listed; no material).

SEALE, 1910: 285 (description; East Malaysia, Sabah, Sandakan; material in PBSF, reg. no. 2527, 2600, 2601, 2628, 2681, 2771).

HERRE, 1924: 497-498 (redescription of Seale, 1910 material).

HORA, 1924: 499 (description, discussion on differences with $T$. fluviatilis cf. Day, 1878; Thailand: Thale Sap, Songkhla; material in ZSI).

Herre, 1933: 5 (listed after Seale, 1910 and Herre, 1924).

INNES, 1935 (in ed. 1956): 496-497, fig. p. 496 (description, aquarium data; no material).

SUVATTI, 1936: 165 (listed; Thailand: Chanthaburi River; material in BFB).

HerRe \& MYers, 1937: 50 (listed; West Malaysia: Ubin Island \& Singapore \& Indonesia: Sumatra Coast 100 miles W. of Singapore; material in NMS).

ROXAS \& MARTIN, 1937: 257 (listed; no material).

HERRE, 1940: 8 (listed; India: Andaman Islands, Middle Andaman, Long Island \& Andaman Islands, South Andaman, Port Blair).

HERRE, 1941: 401 (listed after Herre, 1940).

FRASER-BRUNNER, 1943: 14 (listed as representative of genus and subgenus; no material) (in subgenus Chelonodon).

Koumans, 1947: 311 (listed; West Malaysia: Port Dickson; material in RMNH, reg. no. 17915).

BREDER \& ClARK, 1947: 308 (reference to literature on reproduction; no material).

SMITH, 1945: 577 (description; no additional material).

HERRE, 1953: 841 (listed; no additional material).

BENL, 1956: 4, 6, 7, 10-12 (description, aquarium data; no material).

Boeseman, 1957: 77 (description; Ceylon, Colombo; material in RMNH, reg. no. 20907).

HERRE, 1958: 80 (listed as known to occur on the
Philippines without exact record of such).

MERCKENS, 1958: 53-54 (description, aquarium data; no material).

STERBA, 1959: 634, 637, Taf. 274, 275 (in part) (description, aquarium data; no material).

DE BeAUfORT, 1962: 395 (in part) (description; ZMA material of additional localities identified in present paper as $T$. nigroviridis) (in subgenus Monotretus).

\section{Dichotomycter fluviatilis;}

ABE, 1949: 130-131 (listed; East Malaysia: Sabah, Sandakan \& Sabah, Tawau River at Tawau \& Sabah, Tawau Coast).

Tetraodon kretamensis Inger, 1953.

Figs. 26-28.

\section{Tetraodon kretamensis}

INGER, 1953: 149-152, fig. 27 (original description, nasal organ figured, discussion on differences with $T$. leiurus and $T$. fluviatilis; East Malaysia: Sabah, Kinabatangan District, Kretam Kechil River system, Pinang River (type locality) and other stations of the system (paratypes); material in FMNH, reg. no. 51558 (holotype) and 51562, 51559, 51560, 51561, 51563 (paratypes) ).

INGER, 1955: 52, 55, 81, 82, 85 (description, notes on ecology and food habits; no additional localities).

INGER \& CHIN, 1962: 192, 193, 209, 225, fig. 100B (description, dorsal colour pattern of head figured, discussion on ecology; no additional localities).

De Benufort, 1962: 398, 399 (description after Inger, 1953; no material seen by author) (in subgenus Monotretus).

\section{Description of the paratypes. -}

General morphology. - Body oblong, cylindrical, posteriorly compressed laterally, head region sometimes slightly depressed; dorsal profile arched, highest at midst of back; interorbital convex, without a groove; lateral line system mostly indistinct; spines small except in 1 specimen, mostly hidden under the skin, covering area between eyes and anus; origin of anal fin situated beneath anterior half of dorsal fin base; mouth terminal, directed forwards; lower border of eye at level of mouth corner or lower, upper border not interfering with dorsal profile; nasal organ a tentacle, more than distal half of which is divided in two flattened lobes; apposed surfaces of lobes always without spongy tissue.

Colour in alcohol. - Ground colour of upper parts tan, of belly yellowish white; both colours often separated by an irregular dark band running from mouth below eye and pectoral fin to meet band of other side at anus or behind; back and sides 


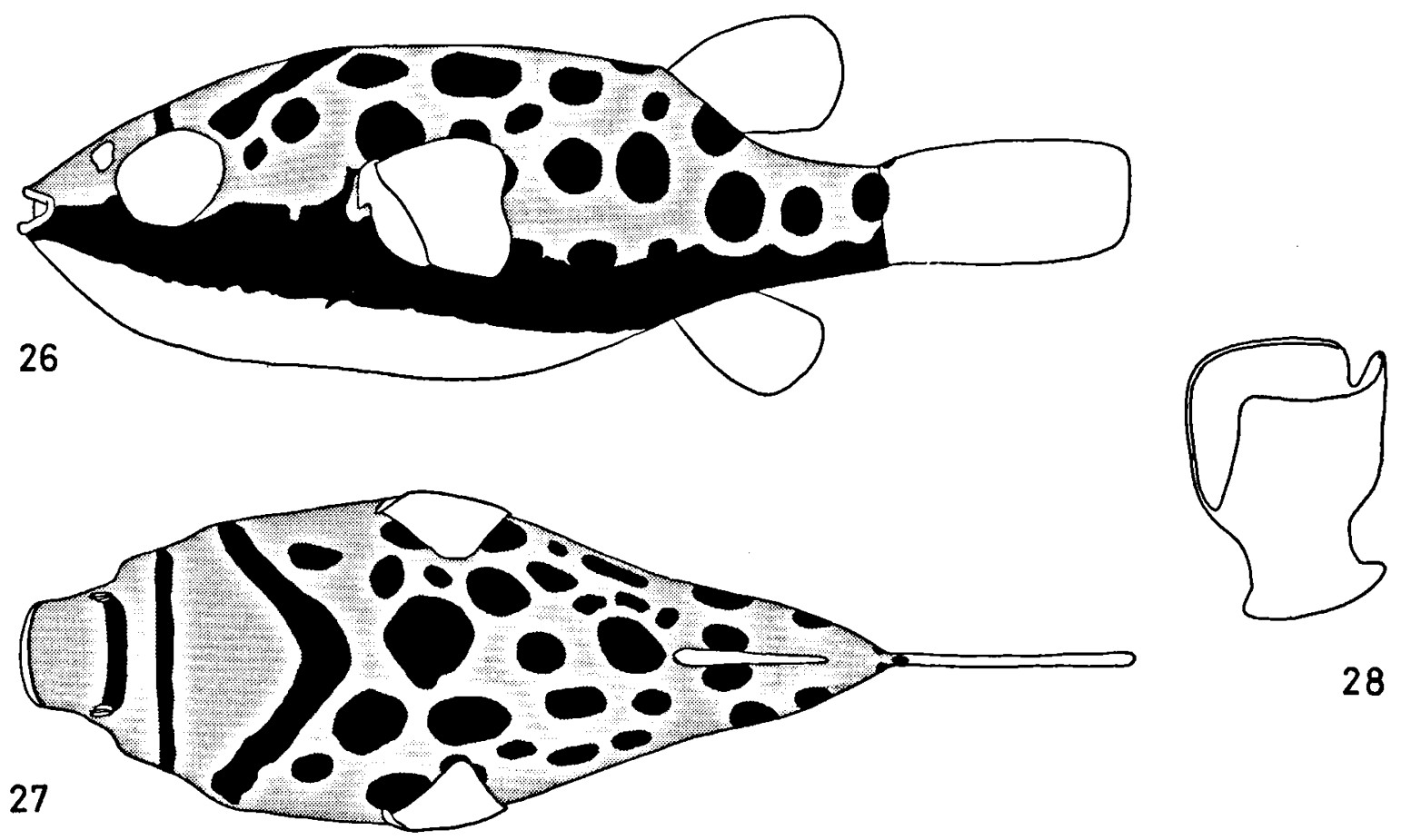

Figs. 26-28. Tetraodon kretamensis Inger, 1953.

Fig. 26. Lateral view of FMNH 5161, paratype, sl $36 \mathrm{~mm}$.

Fig. 27. Dorsal view of FMNH 5161, paratype, sl $36 \mathrm{~mm}$.

Fig. 28. Nasal organ of FMNH 5161, paratype, s1 $36 \mathrm{~mm}$.

with round and oblong dark spots of varying sizes; spots on back sometimes forming an internasal band, an interocular band and/or - most often and most prominent - a curved or V-shaped band crossing most of back between eyes and pectoral fins; lateral spots varying in size and number but always a spot at base of dorsal fin and at base of caudal fin present; belly and chin uniformly yellowish white; caudal fin plain or dusky, in 1 specimen with small dark spots suggesting cross bands; other fins plain.

Morphometrics (based on 11 specimens). - sl 27 45 (m 37) mm; th $33-57$ (m 45) $\mathrm{mm}$; dorsal fin rays 11-13 (m 11.8) of which 2-3 (m 2.4) unbranched, longest ray (the 7-8th) 6.5-7.7 (m 7.0) in sl, shortest ray (the 1st) $18.3-29$ (m 23) in sl, base 8.2-10.7 (m 9.3) in sl and 1.2-1.5 (m 1.3) in longest ray; anal fin rays 10 of which $1-2$ (m 1.4) unbranched, longest ray (the 6-7th) 6.8-7.7 (m 7.2) in sl, shortest ray (the 1st) $17.3-24$ (m 20) in sl; base 10.0-12.9 (m 11.1) in sl and 1.4-1.9 (m 1.6) in longest ray; pectoral fin rays 18-19 (m 18.4) of which 2 unbranched; longest ray (the 5th) 7.1-8.7 in sl; shortest ray (the 1st) $15.7-25$ (m 19.0) in sl, base 7.2-9.2 (m 8.6) in sl and 1.0-1.3 (m 1.1) in longest ray; depth maximum $2.5-3.2$ (m 2.8) in sl, at pectoral fin base 2.7-3.2 (m 2.9) in sl, at end of dorsal fin base 5.3-6.7 (m 6.0) in sl; width maximum 2.4-2.9 (m 2.6) in sl and 0.8-1.1 (m 0.9) in maximum depth, at pectoral fin base 2.7-3.0 (m 2.8) in sl and 0.9-1.1 (m 1.0) in corresponding depth, at end of dorsal fin base 6.6-8.1 (m 7.3) in sl and 1.1-1.4 (m 1.2) in corresponding depth; head length 2.1-2.4 (m 2.2) in sl; snout length 2.6-2.9 (m 2.7) in hl; interocular distance 1.6-2.0 (m 1.8) in $\mathrm{hl}$; eye horizontal diameter $2.8-3.6$ (m 3.2) in $\mathrm{hl}$, distance from dorsal profile 8.6-21 (m 12.8) in $\mathrm{hl}$; nasal organ length 9.4-14.6 (m 12.1) in hl, distance from tip of snout $3.4-4.2$ (m 3.8) in hl, distance from eye 9.4-15.0 (m 12.1) in hl and 2.74.0 (m 3.3) in distance from tip of snout; mouth width 3.0-3.6 (m 3.3) in hl; upper lip depth 15.021 (m 17.4) in hl; lower lip depth 12.9-21 (m 18.7) in $\mathrm{hl}$.

\section{Material examined. -}

FMNH 51559; 5 specimens, paratypes, sl $27-40 \mathrm{~mm}$; East Malaysia: Sabah, Kinabatangan District, Kretam Kechil River system, Pinang River; coll. R. F. Inger, 1950.

FMNH 51560; 2 specimens, paratypes, sl 8.7-9.6 mm; East Malaysia: Sabah, Kinabatangan District, Kretam Kechil River; coll. R. F. Inger, 1950.

FMNH 51561; 2 specimens, paratypes, sl $11.7-36 \mathrm{~mm}$; East Malaysia: Sabah, Kinabatangan District, Kretam 
Kechil River; coll. R. F. Inger, 1950.

FMNH 51562; 5 specimens, paratypes, sl $33-45 \mathrm{~mm}$; East Malaysia: Sabah, Kinabatangan District, Kretam Kechil River system, Gaja River; coll. R. F. Inger, 1950. FMNH 51563; 2 specimens, paratypes, sl 8.2-17.5 mm; East Malaysia: Sabah, Kinabatangan District, Kretam Kechil River system, Gaja River; coll. R. F. Inger, 1950.

Distribution. - T. kretamensis is only known from the Kretam Kechil River system in Sabah, N. Borneo, about 35 miles S.E. of Sandakan. It inhabits the lower reaches of rivers, in brackish waters. The zoogeographical implications of the region are discussed by Inger \& Chin, 1962, who point to the fact that the Labuk-Segama region, as they call it, contains most of the endemic species of primary freshwater fishes. Although kretamensis is not a primary freshwater fish it can thus be argued that it is an endemic species - or perhaps a subspecies - of Tetraodon.

Etymology. - T. kretamensis was named after the type locality, Kretam Kechil River system.

Tetraodon nigroviridis Marion de Procé, 1822. Figs. 29-31.

\section{Tetrodon nigroviridis}

MARION DE PROCÉ, 1822: 130 (original description; Indonesia: N.E. coast of Sumatra, freshwater pool; for material see neotype description).

Tetraödon potamophilus

BLEEKER, 1849a: 16 (original description, discussion on differences with $T$. fluviatilis Hamilton, 1822; Indonesia: Java Sea \& Java, Strait Madura at Kamal and at Surabaya \& Java, river mouths near Djakarta and Semarang; material at least in part in RMNH, reg. no. 7357 ex parte, syntypes).

BLEEKER, 1849b: 12 (listed; no additional localities).

BLEEKER, 1851a: 3, 5 (listed; Indonesia: Borneo, Banjer River $=$ Duson River, near Bandjermasin; material probably in RMNH, reg. no. 7357 ex parte) (in subgenus Chelonodon).

BLEEKER, 1851c: 60 (listed; no additional material).

BLEEKER, 1851d: 262 (listed; no additional material).

BLEEKER, 1851f: 197 (listed; no additional material).

BLEEKER, 1851g: 421 (listed; Indonesia: Borneo \& Indonesia: Sumatra \& Indonesia: Java; probably no additional material).

BLEEKER, 1852a: 4, 5, 7, 10, 17, 18 (description, discussion on differences with $T$. fluviatilis Hamilton, 1822; Indonesia: Java, Panimbang; material probably in RMNH, reg. no. 7357 ex parte).

BLEEKER, 1852d: 408, 409, 415 (listed; Indonesia: Borneo, Pontianak \& Borneo, Pamangkat).

BLEEKER, 1853e: 428, 429, 434, 438 (listed; Indonesia: Borneo, Sambas \& Borneo, Pontianak; material probably in RMNH, reg. no. 7357 ex parte).
Tetrodon simulans

CANTOR, 1849: 1356-1357 (original description; West Malaysia: Malayan Peninsula \& West Malaysia: Pinang \& Singapore; discussion on differences with T. fluviatilis Hamilton, 1822; material at least in part in BMNH, reg. no. 60.3.19: 588-589, syntypes) (in subgenus Arothron).

BLEEKER, 1851b: 476, 478 (listed after Cantor, 1849; no material).

BLEEKER, 1852a: 26 (listed after Cantor, 1849; no material).

BLEEKER, 1852b: 60 (listed after Cantor, 1849; no material).

Arothron potamophilus;

Bleeker, 1854a: 314 (listed; Indonesia: Java, Perdana; material probably in RMNH, reg. no. 7357 ex parte).

BLEEKER, 1854b: 70, 76 (listed; Indonesia: Sumatra, Sibogha \& Indonesia: Java \& Indonesia: Borneo; material probably in RMNH, reg. no. 7357 ex parte).

BLEEKER, 1854d: 260 (listed; Indonesia: Java \& Indonesia: Borneo; material probably in RMNH, reg. no. 7357 ex parte).

BLEEKER, 1855a: 152 (listed; Indonesia: Borneo, Bandjermasin River; material probably in RMNH, reg. no. 7357 ex parte).

BleEker, 1855d: 417 (listed; Indonesia: Borneo, Pontianak \& Borneo, Bandjermasin; material probably in RMNH, reg. no. 7357 ex parte).

BLEEKER, 1856c: 419 (listed; Indonesia: Bangka, Muntok; material probably in RMNH, reg. no. 7357 ex parte).

BLEEKER, 1857c: 12 (listed; no additional material).

BLEEKER, 1858a: 30, 35 (listed; no additional material).

BLEEKER, 1858b: 2 (listed; Indonesia: Borneo, Sinkawang; material probably in RMNH, reg. no. 7357 ex parte).

BLEEKER, 1858c: 444, 445 (listed; Indonesia: Java, Djakarta \& Java, Perdana \& Java, Krawang \& Java, Tjikao \& Java, Samarang \& Java, Surabaya; material probably in RMNH, reg. no. 7357 ex parte).

BLEEKER, 1859a: 201 (listed; no additional material).

BLEEKER, 1859b: 361, 374 (listed; Indonesia: Bangka, Blinju, Klabat Bay \& Bangka, Baturussak; material probably in RMNH, reg. no. 7357 ex parte).

BLEEKER, 1859c: 2 (listed; Indonesia: Borneo, Sinkawang; material probably in RMNH, reg. no. 7357 ex parte).

BLEEKER, 1859d: 435 (listed; Indonesia: Borneo, Duri River; material probably in RMNH, reg. no. 7357 ex parte).

BLEEKER, 1860a: 66 (listed; no additional material).

BLEEKER, 1860b: 447 (listed; Singapore; no material, just seen in sketchbook of De Castelnau).

BLEEKER, 1860c: 7 (listed; no additional material).

BLEEKER, 1860f: 238 (listed; Singapore; no material, just seen in sketchbook of De Castelnau).

BLEEKER, 1861b: 12 (listed; no additional material).

BLEEKER, 1863: 73 (listed; Indonesia: Bangka; material probably in RMNH, reg. no. 7357 ex parte).

Dichotomyctère fluviatilis;

BIBRon (in DumÉRIL), 1855: 278 (listed as type of genus; material in MNHN, reg. no. B 1500).

Arothron simulans;

BleEKer, 1858d: 251 (listed after Cantor, 1849; no material).

BLYTH, 1860: 173 (listed; Burma: Moulmein).

BLEEKER, 1861a: 69 (listed after Cantor, 1849; no material). 
Bleeker, 1861b: 40 (listed after Cantor, 1849; no material).

Crayracion fluviatilis;

BleEKER, 1865a: 68, tab. 210 fig. 4 (description, lumping of $T$. potamophilus Bleeker, 1849 with $T$. fluviatilis Hamilton, 1822; no additional localities; material probably mostly in RMNH, reg. no. 7357 ex parte).

KNER, 1867: 408 (description; Indonesia: Java; material probably in NMW).

BLEEKER, 1868b: 290, 385 (listed; Indonesia: Bintang, Rio; material probably in RMNH, reg. no. 7357 ex parte).

Tetrodon fluviatilis;

GüNTHER, 1870: 299-300 (in part) (description; material includes syntypes of $T$. simulans Cantor, 1849 and Bleeker material of $T$. potamophilus Bleeker, 1849) (in subgenus Arothron).

Tirant, 1885 (in ed. 1929): 94-95 (description; South Vietnam: surroundings of Saigon and Cho Lon) (in subgenus Arothron).

RANDOW, 1934: 561-563 (field observations and aquarium data; Ceylon; no preserved material).

Dichotomycter fluviatilis;

FowLER, 1937: 264, fig. 297 (listed; Thailand: Tachin; material probably in ANSP).

Dichotomycterus fluviatilis;

LE Danols, 1959: 132, 135-137, 246, 247, 250, 253255, figs. 84B, 89, 90, 91 (description; lateral view, dorsal view, skull and nasal organ figured; discussion on differences with $T$. nigroviridis Marion de Procé, 1822 and Dichotomyctère javanicus Bibron, MS., evolution, zoogeography, osteology, sexual dimor- phism; material in MNHN, not specified).

LE DANO1S, 1961 (listed in type list of MNHN as senior synonym of material used by Bibron in establishing the genus Dichotomyctère; material in MNHN, reg. no. B1500).

LE DanoIS, 1962: 694-700 (discussion on supposed morphological and osteological transitions between D. rangoonensis Le Danois, 1959 and $D$. fluviatilis cf. Le Danois, $1959=T$. nigroviridis).

Tetraodon fluviatilis;

MERCKENS, 1958: 54, 55 (in part), fig. p. 53 (description, aquarium data; no material).

STERBA, 1959: 827 (in part), Taf. 274 (description, aquarium data; no material).

SCHNEIDER, 1964: $414-435$, figs. 1, 3-9 (anatomical studies of fin musculature).

DE BEAUFORT, 1962: 392, 395-397 (in part) (description; Indonesia: Java, Djakarta \& Java, Tjilatjap \& Indonesia: Sumatra, Deli; material in ZMA, reg. no. $108.952,108.953,108.955$, respectively) (in subgenus Monotretus).

Tetraodon leiurus;

INGER \& CHIN, 1962: 191-192, fig. 102 (description, ecology; East Malaysia: Borneo, Sabah, Tawau District, Kalabakan River; material in FMNH, reg. no. 68480).

\section{General description. -}

General morphology. - Body oblong, posterior part compressed laterally; dorsal profile arched,
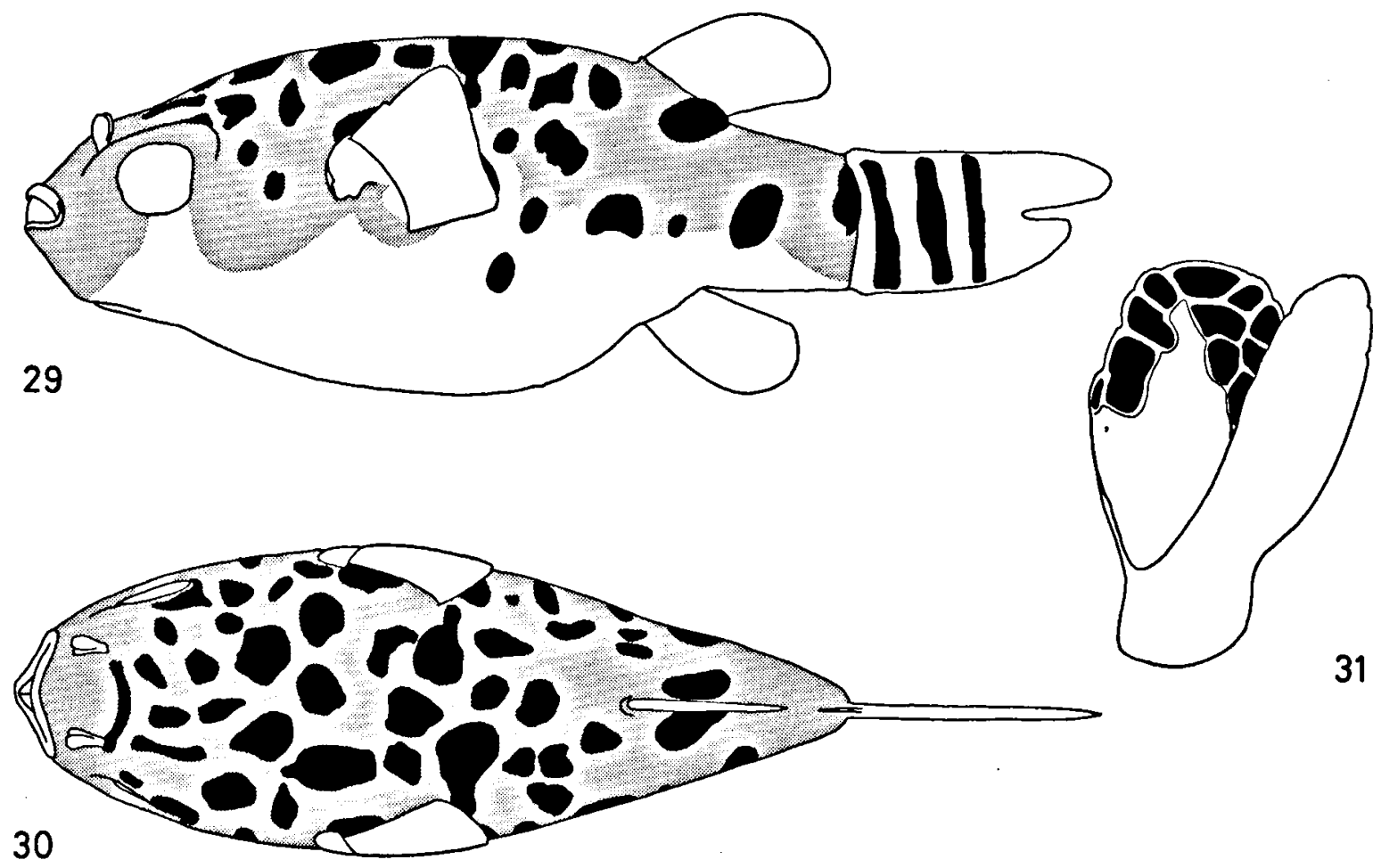

Figs. 29-31. Tetraodon nigroviridis Marion de Procé, 1822

Fig. 29. Lateral view of ZMA 113.020, neotype, sl $64 \mathrm{~mm}$.

Fig. 30. Dorsal view of ZMA 113.020, neotype, sl $64 \mathrm{~mm}$.

Fig. 31. Nasal organ of ZMA 113.020, neotype, sl $64 \mathrm{~mm}$. 
highest at midst of back; interorbital convex, without a groove; lateral line system mostly indistinct; body spines small, often hidden under skin for most part, not papillose, covering back, sides and belly from eyes to anus; origin of anal fin situated slightly anterior of dorsal fin or beneath anterior half of dorsal fin base; mouth terminal, directed forwards; lower border of eye slightly above level of mouth corner, upper border not interfering with dorsal profile; nasal organ a tentacle, at least distal half of which is divided into two flattened and broadened lobes; apposed surfaces of lobes often with spongy tissue (in $50 \%$ of specimens $\geqslant 60 \mathrm{~mm}$ sl, $\mathrm{N}=19$; in $15 \%$ of specimens $<60 \mathrm{~mm} \mathrm{sl}$, $\mathrm{N}=29$ ).

Colour in alcohol. - Ground colour of upper parts tan, of lower parts yellowish white; back and sides covered with many dark spots and rounded blotches (maximal diameter 10-100 in sl); spots and blotches very variable in size and form, sometimes coalescent, sometimes encircled by lighter rings thus forming ocelli, sometimes stretched into thick longitudinal rows on caudal peduncle; spots and blotches of one specimen sometimes present in one size only, sometimes present in all possible sizes; ground colour often broken up by spots and blotches into spots and streaks; caudal fin mostly with 1.8 (m 3.8) dark transverse bands (in $65 \%$ of 60 specimens); dorsal fin sometimes with some small dark spots near base; other fins plain; belly uniformly whitish.

Morphometrics (based on 60 specimens). - sl 26143 (m 53) mm; tl 34-185 (m 70) mm; dorsal fin rays $12-14$ (m 13.1) of which $2-4$ (m 2.8) unbranched, longest ray (the 7-8th) 5.8-9.8 (m 7.3) in sl, shortest ray (the 1st) 16.4-26 (m 20) in sl, base 6.7-11.0 (m 8.1) in sl and 0.9-1.4 (m 1.1) in longest ray; anal fin rays $10-12$ (m 11.4) of which 1-3 (m 1.9) unbranched, longest ray (the 5-7th) 6.4-8.6 (m 7.5) in sl, shortest ray (the 1st) 13.8-22 (m 18.1) in sl, base 7.5-12.5 (m 9.5) in sl and 1.0-1.6 (m 1.4) in longest ray; pectoral fin rays 18-23 (m 20.4) of which 1-3 (m 2.1) unbranched, longest ray (the 5-7th) 6.0-10.7 (m 7.8) in sl, shortest ray (the 1st) 15.2-23 (m 18.8) in sl, base 6.7-11.0 (m 8.4) in sl and 0.9-1.3 (m 1.1) in longest ray; depth maximum 1.9-3.2 (m 2.7) in sl, at pectoral fin base 2.1-3.4 (m 2.8) in sl, at end of dorsal fin base 4.2-7.1 (m 5.5) in sl; width maximum 2.1-3.4 (m 2.9) in sl and 0.9-1.5 (m 1.1) in maximum depth, at pectoral fin base 2.7-3.6 (m 3.1) in sl and 0.9-1.4 (m 1.1) in corresponding depth, at end of dorsal fin base 5.7-10.7 (m 7.6) in sl and 1.0-2.2 (m 1.4) in corresponding depth; head length 2.1-2.6 (m 2.4) in sl; snout length 2.3-2.9 (m 2.7) in hl; eye horizontal diameter 2.8-5.4 (m 3.9) in hl, distance from dorsal profile 5.8-16.9 (m 8.5) in hl; interocular distance 1.5-2.0 (m 1.8) in hl; nasal organ length 7.5-20 (m 10.2) in hl, distance from tip of snout 2.9-4.2 (m 3.4) in hl, distance from eye 7.417.0 (m 10.7) in hl and 2.0-4.6 (m 3.1) in distance from tip of snout; mouth width $2.8-4.4$ (m 3.5) in $\mathrm{hl}$; upper lip depth 7.5-22 (m 13.7) in hl; lower lip depth 12.9-21 (m 15.5) in hl.

\section{Material examined. -}

BMNH 1867.11.28: 108; 1 specimen, sl 126 mm; Indonesia; Bleeker Collection.

BMNH 60.3.19: 588-589; 2 specimens, sl 52, $125 \mathrm{~mm}$, preserved dry; West Malaysia; coll. E. J. Comp. (syntypes of $T$. simulans Cantor, 1849).

BMNH, no reg. no.; 1 specimen, sl 65 mm; Philippines; coll. H. Cuming, 1836-1840.

FMNH 68480; 1 specimen, sl $58 \mathrm{~mm}$; East Malaysia: Borneo, Sabah, Tawau District, Kalabakan River; coll. R. F. Inger, 2-VI-1956.

MNHN 95-207, 208; 2 specimens, sl 60, $60 \mathrm{~mm}$; Thailand; coll. Bellanger.

NMW 64.297; 1 specimen, sl $69 \mathrm{~mm}$; China: Hongkong; 1866.

RMNH 4580; 1 specimen, sl $70 \mathrm{~mm}$; Indonesia: Borneo, Bandjermasin; coll. J. Semmelinck.

RMNH 7357; 61 specimens, tl 40-160 mm; Indonesia; Bleeker Collection.

SMM 24403; 10 specimens, sl 30-35 mm; live imported from India: Calcutta; coll. A. Werner, 1956.

ZMA 102.307; 3 specimens, sl $53-62 \mathrm{~mm}$; Indonesia; Bleeker Collection.

ZMA $108.950 ; 18$ specimens, sl $45-57 \mathrm{~mm}$; Indonesia: Borneo; coll. Teysman, 1877; ex KMA.

ZMA $108.952 ; 3$ specimens, sl $45-68 \mathrm{~mm}$; Indonesia: Java, Bay of Djakarta; coll. J. Buitendijk, I-1910.

ZMA 108.953; 2 specimens, sl $77-79 \mathrm{~mm}$; Indonesia: Java, Tjilatjap; coll. E. Jacobson, III-1911.

ZMA 108.955; 4 specimens, sl $56-143 \mathrm{~mm}$; Indonesia: Sumatra, Deli; coll. L. P. Cosquino de Bussy, 19.05/ 1907.

ZMA 110.211; 1 specimen, sl $72 \mathrm{~mm}$; Indonesia: South Natuna Island; coll. Van Roosendaal; ex LOZB.

ZMA 110.214; 1 specimen, sl $117 \mathrm{~mm}$; Indonesia: Borneo, Balikpapan; coll. Tissot van Patot, 1911.

ZMA 110.217; 2 specimens, sl $35,36 \mathrm{~mm}$; Indonesia: Borneo, Upper Riko River; coll. Tissot van Patot, 1911. ZMA 110.375; 17 specimens, sl 26-75 mm; Indonesia: Borneo, Kota Baru; coll. H. A. Lorentz, 28-V-1909.

ZMA 112.470; 1 specimen, sl $74 \mathrm{~mm}$; Indonesia: Java, Djakarta; coll. J. Verwey; ex LOZB.

ZMA 113.020; 1 specimen, sl $64 \mathrm{~mm}$; Indonesia: Sumatra, Deli; coll. L. P. Cosquino de Bussy, 1905/1907 (neotype).

\section{Description of the neotype. -}

Designation. - Marion de Procé based his original 
description on a single specimen collected during a trip from France to Manila, Philippines. As stated in an introductory note most of the collections made during the trip got lost in a revolt. The descriptions were partly made on the basis of drawings only. I assume the holotype of $T$. nigroviridis to have been among the lost part of the collection, both because I could not trace it and because of the past tence of the word "avait" in the next sentence accompanying the original description: "Un seul individu, observé dans une mare d'eau douce sur la côte N.E. de Sumatra, avait environ 21/2 pouces de long" (Marion de Procé, 1822: 130).

The holotype being lost and the species being part of a very complicated species-group or superspecies, I thought it in accordance with the International Code of Zoological Nomenclature to designate a neotype. I choose it from a series collected in Sumatra, Deli, as Deli is an old "residentie" (province) of N.E. Sumatra (situated around Medan). From the series I choose the specimen most closely matching the fin formula as given by Marion de Procé (D 12; A 10; P 18). The remaining difference compared to the formula of the neotype (D 13; A 11; P 21) can be explained by inaccurate counting by Marion de Procé (most ichthyologists did not count the small foremost dorsal and anal fin rays) and, of course, by the variability in fin ray counts of the species, being from my experience D 12-14; A 10-12; P 18-23.

General morphology. - Body posterior of eyes compressed laterally; lateral line system distinct; body spines from nasal organs to anus, most densely distributed anteriorly and ventrally, most distinctly two-rooted anteriorly and dorsally; origin of anal fin slightly anterior of dorsal fin; nasal organ flaps nearly reaching to base of nasal organ, apposed surfaces with distinct (left organ) or indistinct (right organ) spongy tissue; otherwise like general description.

Colour in alcohol. - Back and sides in total with ca. 50 dark spots (diameter 2-5 mm), mostly rounded, in 4 cases 2 spots coalescent; caudal fin with 3 distinct and 1 indistinct transverse dark bars; other fins plain; otherwise like general description.

Morphometrics. - sl $64 \mathrm{~mm}$; tl $84 \mathrm{~mm}$; dorsal fin rays ii.11, longest ray (the 7 th) $10.1 \mathrm{~mm}(6.3 \mathrm{in} \mathrm{sl})$, shortest ray (the 1st) $3.9 \mathrm{~mm}$ (16.4 in sl), base $8.5 \mathrm{~mm}$ ( 7.5 in sl and 1.2 in longest ray); anal fin rays ii.9, longest ray (the 5 th) $9.2 \mathrm{~mm}(7.0$ in sl), shortest ray (the 1st) $4.6 \mathrm{~mm}$ (13.9 in sl), base $6.3 \mathrm{~mm}$ (10.1 in sl and 1.4 in longest ray); pectoral fin rays ii.19, longest ray (the 6th) $9.0 \mathrm{~mm}$ (7.1 in sl), shortest ray (the 1st) $3.2 \mathrm{~mm}$ (20 in sl), base $8.0 \mathrm{~mm}$ ( 8.0 in sl and 1.2 in longest ray); depth maximum $27 \mathrm{~mm}$ (2.4 in sl), at pectoral fin base $26 \mathrm{~mm}$ (2.5 in sl), at end of dorsal fin base 14.1 $\mathrm{mm}$ (4.5 in sl); width maximum $23 \mathrm{~mm}$ ( 2.8 in sl and 1.2 in maximum depth), at pectoral fin base $23 \mathrm{~mm}$ (2.8 in sl and 1.1 in corresponding depth), at end of dorsal fin base $11.3 \mathrm{~mm}(5.7$ in sl and 1.3 in corresponding depth); head length $29 \mathrm{~mm}$ (2.2 in sl); snout length $11.8 \mathrm{~mm}$ (2.4 in $\mathrm{hl})$; eye horizontal diameter $5.4 \mathrm{~mm}(5.4 \mathrm{in} \mathrm{hl})$, distance from dorsal profile $2.8 \mathrm{~mm}$ (10.4 in hl); interocular distance $16.8 \mathrm{~mm}$ (1.7 in $\mathrm{hl})$; nasal organ length $3.5 \mathrm{~mm}(8.3 \mathrm{in} \mathrm{hl})$, distance from tip of snout $10.0 \mathrm{~mm}$ ( $2.9 \mathrm{in} \mathrm{hl})$, distance from eye 3.1 $\mathrm{mm} \mathrm{(9.4} \mathrm{in} \mathrm{hl}$ and 3.2 in distance from tip of snout); mouth width $10.3 \mathrm{~mm}$ (2.8 in $\mathrm{hl}$ ); upper lip depth $1.7 \mathrm{~mm}$ (17.1 in $\mathrm{hl})$; lower lip depth $1.9 \mathrm{~mm}(15.3 \mathrm{in} \mathrm{hl})$.

\section{Material examined. -}

ZMA 113.020; 1 specimen, sl $64 \mathrm{~mm}$; Indonesia: Sumatra, Deli; coll. L. P. Cosquino de Bussy, 1905/1907 (neotype).

Distribution. - As seen from the synonyms, references, and material examined the present species is known from Ceylon, Burma, Thailand, West and East Malaysia, Bintan, Sumatra, Bangka, Iava, Borneo, Natuna Islands, and South Vietnam.

The Chinese (Hongkong) specimen examined is no proof for the species occurring there, since the collector is unknown, the collecting date is long ago (1866), and no other specimens from the region were subsequently recorded. The material imported from Calcutta is no proof either, as this town is a well-known transit station in the international aquarium trade.

Herre, 1924, discusses the presence or absence of the species on the Philippines and gives two arguments for its presence: the presumed type locality, Manila, and a specimen recorded by Günther, 1870, which was collected by Hugh Cuming. The first argument is based on persistent copying by many authors of the synonymy lists of earlier authors, as the type locality in fact is N.E. Sumatra. The second argument is quite poor as Hugh Cuming is known to have been quite careless in labelling his collections. Because no other material was recorded from Manila since Cuming, it seems wise to await new material before 
indicating the Philippines as part of the distributional area.

Etymology. - The name nigroviridis is derived from the Latin "niger", meaning "black" (referring to the dark spots), and the Latin "viridis", meaning "green" (referring to the colour of the upper parts in living specimens).

Tetraodon fluviatilis fluviatilis Hamilton, 1822.

Figs. 32-34.

\section{Tetrodon fluviatilis}

Hamilton, 1822: $6-7,362$, pl. 30 fig. 1 (original description, lateral and dorsal view figured; India, WestBengal or Bangla Desh: Ganges River system; no material known, see neotype description).

GüNTHER, 1870: 299-300 (in part) (description; India: Malabar; material in BMNH) (in subgenus Arothron).

DAY, 1878: 707, pl. 183 fig. 1 (description; discussion on Bleeker material from Indo-Malayan Archipelago; India; material in part in BMNH) (in subgenus Arothron).

DAY, 1889: 496 (description after Day, 1878; additional locality from mutual communication: Burma: Amherst District; no additional material).

ANNANDALE \& JENKINS, 1910: 15-16 (description of two varieties: var. A after Hamilton, 1822 and var. B after Day, 1878; A: India: Orissa Coast \& India: Ganges River at Sara Ghat; B: India: Sattermukhi River; material probably in ZSI).

RANDOW, 1934: 561-563 (field observations, aquarium data; Ceylon; no material).

Tetraodon fluviatilis;

SWAINSON, 1839: 328 (listed as representative of genus; no material).

INGER, 1953: 150-152 (in part) (in discussion on differences with $T$. kretamensis and North Bornean specimens of $T$. fluviatilis; India: Ganges River at Allahabad; material in BMNH, reg. no. 1934.10.17: 139149).

BENL, 1956: Abb. 4 (figure illustrating description of $T$. fluviatilis sensu lato; no material).

STERBA, 1959: Taf. 274 (figure illustrating description of T. fluviatilis sensu lato; no material).

MerCKENS, 1958: 54, 55 (in part), fig. p. 51, 54 (description, aquarium data; no material).

Tetraödon fluviatilis;

BLEEKER, 1853a: 78 (listed after Hamilton, 1822; no material).

Arothron dorsovittatus

BLYTH, 1860: 173-174 (original description; India: Calcutta, fish bazaars; material not in ZSI or BMNH).

Crayracion fluviatilis;

DAY, 1865: 314 (description of fin formulae only; no material).

Chelonodon fluviatilis;

MuNRo, 1955: 282, pl. 55 fig. 822 (description; Ceylon; no material).

MENON, 1961b: 401 (listed; India: Sunnamber River at Nonankuppam \& India: Pondicherry \& India: Tranquebar; material probably in ZSI).
Dichotomycterus rangoonensis;

LE DANOIS, 1959: 21, 133-135, 246-248, 250, 251, 253, 254, figs. $84 \mathrm{~A}, 85-88$ (original description, lateral view, dorsal view, frontal view, skull and nasal organ figured; key; discussion on osteology, evolution, zoogeography, development, differences with $T$. fluviatilis cf. Hamilton, 1822, id. cf. Day, 1878, and T. viridipunctatus Day, 1865; Burma: surroundings of Rangoon \& Bengal; material in MNHN, including B 1564).

LE DANOIS, 1961: 462 (in type list of MNHN; no additional material).

LE DANOIS, 1962: 694-700, figs. 1-11 (discussion with figures on morphological and osteological transitions between $D$. rangoonensis Le Danois, 1959 and $D$. fluviatilis cf. Le Danois, $1959=T$. nigroviridis; material in MNHN, including reg. no. 61-1117).

Chelanodon fluviatilis;

MENON, 1961a: 50, 56, 61 (listed, description in key; India: Chilka Lake off Bhasra Id; material probably in ZSI).

Dichotomycterus rangoonensis dorsovittatus;

LE DanoIS, 1962: 694-700, figs. 3, 5, 9 (description; Indo-Malayan Archipelago; material in MNHN, reg. no. 61-1117 no. 3, indicated as "type").

\section{General description. -}

General morphology. - Body oblong, compressed laterally except in fleshy specimens; dorsal profile arched, highest at midst of back; interorbital convex, without a groove; lateral line system distinct; body spines small, sometimes very distinctly two-based, sometimes partly or wholly indistinct, covering back, sides, and belly between eyes and origin of dorsal fin; origin of anal fin situated beneath anterior half of dorsal fin base; mouth terminal, directed forwards; lower border of eye slightly above or below level of mouth corner, upper border not interfering with dorsal profile; nasal organ a tentacle, more than distal half of which is divided in two flattened and broadened lobes; apposed surfaces of lobes generally with spongy tissue (in $90 \%$ of specimens $\geqslant 60 \mathrm{~mm} \mathrm{sl}, \mathrm{N}=20$; in $80 \%$ of specimens $<60$ $\mathrm{mm} \mathrm{sl,} \mathrm{N}=5$ ).

Colour in alcohol. - Ground colour of upper parts tan, of belly yellowish white; three large yellowishencircled dark patches on back between eyes and dorsal fin: anterior patch on posterior half of head (length along midline of back $6.2-14.0$ in sl, and 1.3-2.9 in transverse length), middle patch between pectoral fins (length along midline of back 5.5-13.8 in sl, and 0.8-1.8 in transverse length), posterior patch in front of dorsal fin (length along midline of back 8.3-14.4 in sl, and 0.6-1.3 in transverse length); middle dorsal patch occasionally broken up into 


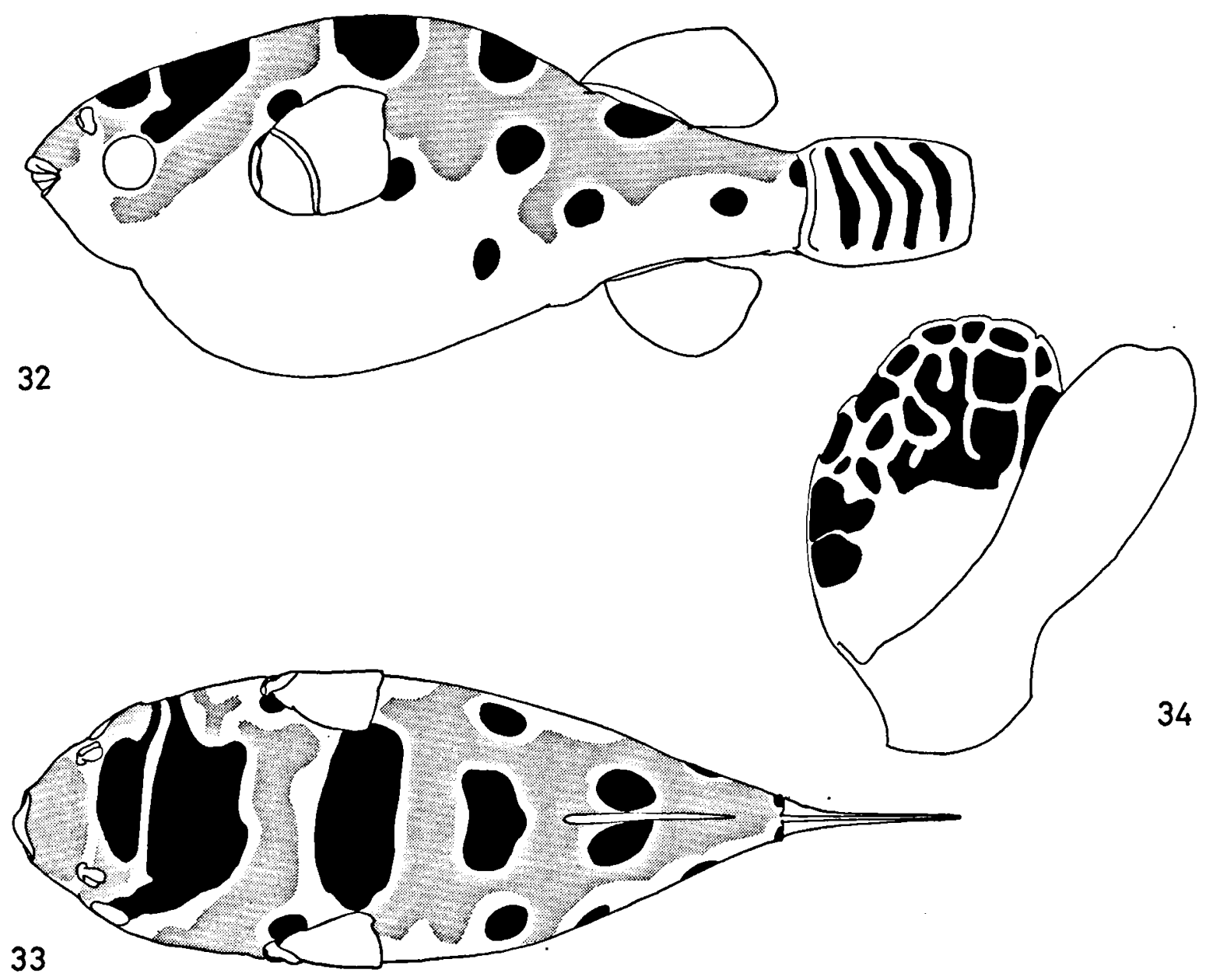

Figs. 32-34. Tetraodon fluviatilis fluviatilis Hamilton, 1822.

Fig. 32. Lateral view of BMNH 1934.10.17: 139, neotype, sl $93 \mathrm{~mm}$.

Fig. 33. Dorsal view of BMNH 1934.10.17: 139, neotype, sl $93 \mathrm{~mm}$.

Fig. 34. Nasal organ of ZMA 108.954, sl $58 \mathrm{~mm}$.

two smaller patches; anterior half of head variably coloured, often irregularly dark; sides with 5-28 rounded, mostly ocellated, dark spots (horizontal diameter 8-80 in sl) of which always one at base of dorsal fin (usually the largest), one at base of caudal fin (usually the smallest), and one below or against posterior dorsal patch; belly uniform yellowish white or with same but confluent spots as on sides (especially in MNHN 61-1117); 0-9 (m 3.8) crossbars on caudal fin; sometimes a small dark spot on interior side of pectoral fin base; other fins plain.

Morphometrics (based on 25 specimens). - sl 31$108 \mathrm{~mm}$ (m $80 \mathrm{~mm}$ ); tl $39-127 \mathrm{~mm}$ (m $96 \mathrm{~mm}$ ); dorsal fin rays 13-16 (m 14.9) of which 1-4 (m 3.1) unbranched, longest ray (the 6-10th) 6.0-7.5 (m 6.7) in sl, shortest ray (the 1st) $19.2-37$ (m 23) in sl, base 5.9-8.0 (m 6.8) in sl and 0.9-1.2 (m 1.0) in longest ray; anal fin rays 11-14 (m 13.1) of which 2-4 (m 2.1) unbranched, longest ray (the 5-9th) 6.1-8.1 (m 7.1) in sl, shortest ray (the 1st) $16-29$ in sl, base 6.6-9.7 (m 8.3) in sl and 0.9-1.4 (m 1.2) in longest ray; pectoral fin rays 19-24 (m 20.7) of which 1-3 (m 2.0) unbranched, longest ray (the 4-6th) 6.9-8.8 (m 7.9) in sl, shortest ray (the 1st) 18.3-27 (m 23) in sl, base 7.1-9.1 (m 8.4) in sl and 0.9-1.3 (m 1.1) in longest ray; depth maximum 2.4-3.2 (m 2.8) in sl, at pectoral fin base 2.4-3.4 (m 2.9) in sl, at end of dorsal fin base 4.9-6.5 (m 5.7) in sl; width maximum 3.1-4.0 (m 3.5) in sl and 1.1-1.5 (m 1.3) in maximum depth, at pectoral fin base 3.1-4.6 (m 3.6) in sl and 1.0-1.5 (m 1.3) in corresponding depth, at end of dorsal fin base 4.9-8.3 (m 7.2) in $\mathrm{sl}$ and 1.1-1.5 (m 1.3) in corresponding depth; head length 2.4-3.1 (m 2.7) in sl; snout length $2.3-2.9$ (m 2.6) in hl; interocular distance 1.5-2.0 (m 1.8) in $\mathrm{hl}$; eye horizontal 
diameter 3.0-4.8 (m 4.3) in $\mathrm{hl}$, distance from dorsal profile 4.8-9.7 (m 7.2) in hl; nasal organ length 7.1-11.9 (m 8.9) in hl, distance from tip of snout 2.8-3.6 (m 3.2) in hl, distance from eye 6.5-13.8 (m 9.8) in $\mathrm{hl}$ and 2.1-4.4 (m 2.8) in distance from tip of snout; mouth width $3.0-3.9$ (m 3.4) in hl; upper lip depth 10.4-14.7 (m 12.3) in hl; lower lip depth 14.4.26 (m 22) in hl.

Material examined. -

BMNH 1911.12.6: 48; 1 specimen, sl 78 mm; Kurrachu (= India: Karachi ?); coll. J. W. Townsend.

BMNH 1934.10.17: 139; 1 specimen, sl $93 \mathrm{~mm}$; see neotype description.

BMNH 1934.10.17: 140-149 + BMNH, no reg. no.; $10+9$ specimens, sl 75-108 mm; India: Ganges River at Allahabad; coll. Das (series to which neotype belongs).

BMNH, no reg. no.; 1 specimen, sl $78 \mathrm{~mm}$; India: Malabar; coll. F. Day.

MNHN $61-1117 ; 4$ specimens, sl $73-86 \mathrm{~mm}$; IndoMalayan Archipelago; coll. Arnoult; ex MPD (described by Le Danois (1962: 695) as: "types de transition entre Dichotomycterus rangoonensis et $D$. fluviatilis").

MNHN B 1468; 1 specimen, sl $48 \mathrm{~mm}$; India or Bangla Desh: Ganges River; coll. Dussumier, ca. 1820.

MNHN B 1564; 5 specimens, sl 68-106 mm; Burma: mouth of Rangoon; coll. Reynaud, Expédition Chevrette, 1829 (syntypes of Dichotomycterus rangoonensis Le Danois, 1959).

NMW 64.048; 1 specimen, sl $82 \mathrm{~mm}$; Burma: Akyab; coll. Godeffroy, 1870.

NMW 64.292; 2 specimens, sl $31-42 \mathrm{~mm}$; Burma: Rangoon; coll. Fea, 1893.

ZMA $108.954 ; 2$ specimens, sl $58-59 \mathrm{~mm}$; Bangla Desh: Ganges Delta at Khulna; coll. S. S. "Golden Crown"; coll. N. Annandale; ex IMC.

\section{Description of the neotype. -}

Designation. - As stated earlier, Hamilton did not leave type material of the many species he described (Gudger, 1924; Hora, 1929). According to general custom the excellent drawings accompanying the descriptions are taken as the basis for the species. In the present case this seems to be insufficient. Bleeker (1865a), Cantor (1849), Le Danois (1959) and other authors in their efforts to discriminate related forms, suffered from lack of type material. Because of this, and in connection with the (re)description of closely related species and subspecies in the present paper, I consider the selection of a neotype a prerequisite for reducing taxonomical confusion within the group. There were several reasons to choose the specimen here indicated as the neotype: it is collected from the type locality river system, it is in a quite good state of preservation compared with the examined other series in American and European museums, it belongs to a relatively large, homogeneous series, the colour pattern is well preserved, and the morphological characters fit very well with the general description.

General morphology. - Body spines covering back, sides and belly between eyes and anus, distinctly two-rooted with exception of spines on anterior part of back; nasal organ with spongy tissue; otherwise like general description.

Colour in alcohol. - Anterior dorsal patch length along midline of back $24 \mathrm{~mm}$ (3.9 in sl, 2.1 in transverse length); middle dorsal patch length along midline of back $10.7 \mathrm{~mm}(8.7 \mathrm{in} \mathrm{sl,} 1.8$ in transverse length); posterior dorsal patch length along midline of back $9.6 \mathrm{~mm}(9.7$ in sl, 1.1 in transverse length); 8 spots on each side, horizontal diameter 4.4-7.5 mm (12-21 in sl); caudal fin with 4 dark transverse bars; other fins plain; otherwise like general description.

Morphometrics. - sl $93 \mathrm{~mm}$; tl $112 \mathrm{~mm}$; dorsal fin rays iii.12, longest ray (the 7th) $12.9 \mathrm{~mm}(7.2$ in sl), shortest ray (the $1 \mathrm{st}) 4.4 \mathrm{~mm}$ (21 in sl), base $14.2 \mathrm{~mm}$ (6.5 in sl and 0.9 in longest ray); anal fin rays ii.11, longest ray (the 5th) $12.0 \mathrm{~mm}$ (7.8 in sl), shortest ray (the 1st) $5.0 \mathrm{~mm}$ (18.6 in sl), base $11.3 \mathrm{~mm}(8.2 \mathrm{in} \mathrm{sl}$ and 1.1 in longest ray); pectoral fin rays ii.18, longest ray (the 5 th) $11.5 \mathrm{~mm}(8.1$ in sl), shortest ray (the 1st) $4.0 \mathrm{~mm} \mathrm{(23} \mathrm{in} \mathrm{sl),}$ base $11.3 \mathrm{~mm}(8.2$ in sl and 1.0 in longest ray); depth maximum $35 \mathrm{~mm}$ ( 3.0 in sl), at pectoral fin base $35 \mathrm{~mm} \mathrm{(3.0} \mathrm{in} \mathrm{sl),} \mathrm{at} \mathrm{end} \mathrm{of} \mathrm{dorsal} \mathrm{fin} \mathrm{base}$ $17.3 \mathrm{~mm}$ (5.4 in sl); width maximum $29 \mathrm{~mm}$ (3.2 in sl and 1.2 in maximum depth), at pectoral fin base $28 \mathrm{~mm}$ (3.3 in sl and 1.3 in corresponding depth), at end of dorsal fin base $15.7 \mathrm{~mm}(6.0$ in sl and 1.1 in corresponding depth); head length $31 \mathrm{~mm}$ (3.0 in sl); snout length $10.7 \mathrm{~mm}(2.9 \mathrm{in} \mathrm{hl})$; interocular distance $20 \mathrm{~mm}(1.6 \mathrm{in} \mathrm{hl})$; eye horizontal diameter $7.8 \mathrm{~mm}(4.0 \mathrm{in} \mathrm{hl})$, distance from dorsal profile $6.3 \mathrm{~mm}$ (4.9 in $\mathrm{hl}$ ); nasal organ length $4.0 \mathrm{~mm}(7.8 \mathrm{in} \mathrm{hl})$, distance from tip of snout $10.0 \mathrm{~mm}(3.1 \mathrm{in} \mathrm{hl})$, distance from eye 3.8 $\mathrm{mm}(8.2$ in $\mathrm{hl}$ and 2.6 in distance from tip of snout); mouth width $10.3 \mathrm{~mm}$ (3.0 in hl); upper lip depth $2.4 \mathrm{~mm}$ (12.9 in hl); lower lip depth 2.1 $\mathrm{mm}$ (14.8 in $\mathrm{hl})$.

Material examined. -

BMNH 1934.10.17: 139; 1 specimen, sl $93 \mathrm{~mm}$; India: Ganges River at Allahabad; coll. Das (neotype).

Distribution. - Considering the synonyms, refer- 
ences and material examined, $T$. fluviatilis fluviatilis is found in India, Ceylon, Bangla Desh and Burma.

Etymology. - The name fluviatilis is Latin, meaning of a river. It is biologically incorrect in so far that the species is also recorded from brackish water with certainty and from salt water with probability.

Tetraodon fluviatilis sabahensis nov. subsp.

Figs. 35-37.

\section{Tetraodon fluviatilis}

INGER, 1953: 150-152 (in part) (in discussion on differences with $T$. kretamensis and Indian specimens of T. fluviatilis; East Malaysia: Sabah; material in FMNH).

INGER, 1955: 80, 81 (description; East Malaysia: Sabah, Lower Gaja River \& Sabah, Kretam Besar River mouth \& Lower Pinang River; material in FMNH, reg. no. 51564, 51660-51662).

INGER \& CHIN, 1962: 192, fig. 100A, C (description, nasal organ and colour pattern of head figured, ecology; East Malaysia: Sabah, Kinabatangan District,
Kretam Kechil River system, Pinang River; material in FMNH).

General description. -

General morphology. - Body oblong, posteriorly compressed laterally, head region depressed in 2 larger specimens $(90,108 \mathrm{~mm} \mathrm{sl})$; dorsal profile arched, highest at midst of back; interorbital convex, without a groove; lateral line system distinct or indistinct; spines small (comparatively large in 1 specimen, $90 \mathrm{~mm} \mathrm{sl}$ ), sometimes indistinct, covering area between eyes and anus; origin of anal fin situated beneath anterior half of dorsal fin base; mouth terminal, directed forwards; lower border of eye at level of mouth corner, upper border not interfering with dorsal profile; nasal organ a tentacle, more than distal half of which is divided in two flattened and broadened lobes; apposed surfaces of lobes generally with spongy tissue (in all specimens $\geqslant 33 \mathrm{~mm} \mathrm{sl}$ ).

Colour in alcohol. - Ground colour of upper parts
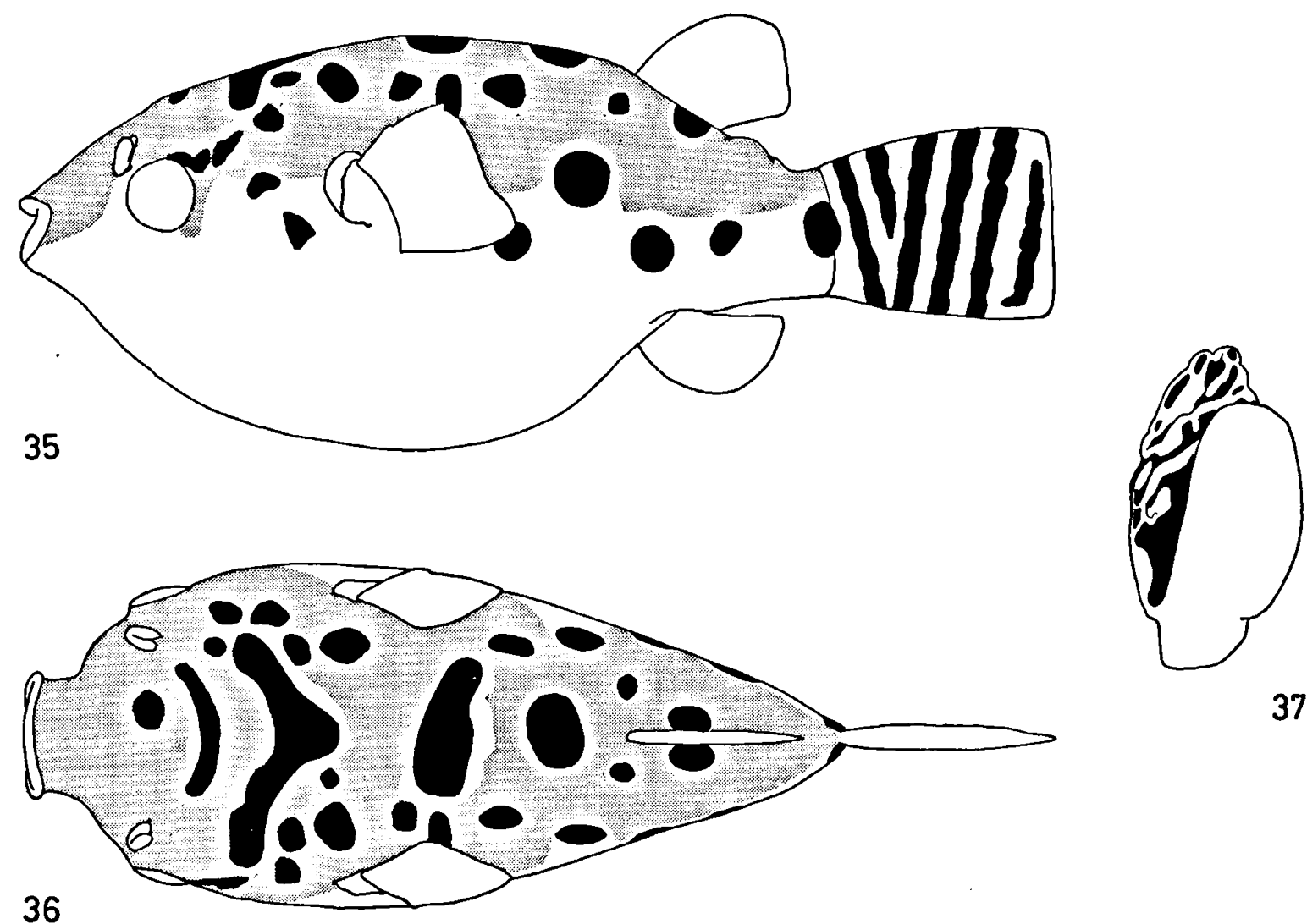

Figs. 35-37. Tetraodon fluviatilis sabahensis nov. subsp.

Fig. 35. Lateral view of FMNH 51564 ex parte, holotype, sl $90 \mathrm{~mm}$.

Fig. 36. Dorsal view of FMNH 51564 ex parte, holotype, sl $90 \mathrm{~mm}$.

Fig. 37. Nasal organ of FMNH 51564 ex parte, holotype, sl $90 \mathrm{~mm}$. 
tan, of lower parts yellowish white; four dark marks on back between eyes and dorsal fin: anteriormost mark a cross band between eyes, in small specimens reduced to a spot, second mark most prominent, V-shaped, pointing backwards (length across back 2.8-5.7 in sl and 2.4-4.8 in length along midline of back), third mark at midst of back, oblong (length across back 6.2-7.6 in sl and 1.4-2.1 in length along midline of back), posteriormost mark just in front of dorsal fin, rounded (length across back 9.0-15.7 in sl and 0.9-1.3 in length along midline of back); often a dark band or spot connecting or between nostrils; sides with 7-16 rounded dark spots (horizontal diameter 11-36 in sl), of which always one at base of dorsal fin, one at base of caudal fin; belly uniformly yellowish white or dirty; caudal fin with 1-7 dark cross bands (m 3.9); other fins plain.

Morphometrics (based on 10 specimens, holotype and paratypes; 1 paratype, sl $13.5 \mathrm{~mm}$, excluded). - sl 30-108 (m 60) mm; tl 40-135 (m 77) mm; dorsal fin rays 13-15 (m 13.8) of which 3-4 (m 3.0) unbranched, longest ray (the 6-9th) 6.5-8.3 (m 7.0) in sl, shortest ray (the 1st) $18-31$ (m 24) in sl, base 7.2-8.8 (m 8.1) in sl and 1.0-1.3 (m 1.2) in longest ray; anal fin rays $11-12$ (m 11.9) of which $2-3$ (m 2.2) unbranched, longest ray (the 5-8th) 6.4-7.7 (m 7.0) in sl, shortest ray (the 1st) 13-18 (m 15.8) in sl, base 9.4-10.9 (m 9.9) in sl and 1.3-1.7 (m 1.4) in longest ray; pectoral fin rays $21-22$ (m 21.8) of which 2 unbranched, longest ray (the 4-6th) 6.2-7.0 (m 6.9) in sl, shortest ray (the 1st) 13-19 (m 16.5) in sl, base 7.6-8.4 (m 8.0) in sl and 1.0-1.3 (m 1.2) in longest ray; depth maximum 2.0-3.0 (m 2.6) in sl, at pectoral fin base 2.4-3.1 (m 2.7) in sl, at end of dorsal fin base 4.6-6.0 (m 5.0) in sl; width maximum 2.3-2.8 (m 2.6) in sl and 0.9-1.1 (m 1.0) in maximum depth, at pectoral fin base 2.5-3.0 (m 2.9) in sl and 0.9-1.3 (m 1.1) in corresponding depth, at end of dorsal fin base 5.3-8.3 (m 6.8) in sl and 1.2-1.5 (m 1.3) in corresponding depth; head length 2.1-2.3 (m 2.2) in sl; snout length 2.2-2.9 (m 2.6) in hl; interocular distance 1.4-1.8 (m 1.6) in hl; eye horizontal diameter 2.8-5.2 (m 3.7) in hl, distance from dorsal profile 7.8-11.7 (m 9.6) in hl; nasal organ length 7.3-12.4 (m 9.4) in hl, distance from tip of snout $2.8-3.8$ (m 3.2) in hl, distance from eye 6.6-20 (m 12.2) in hl and 2.3-5.3 (m 3.8) in distance from tip of snout; mouth width 2.6-3.5 (m 3.1) in hl; upper lip depth 13.8-18.8 (m 16.4) in hl; lower lip depth 15.4-26 (m 21) in hl.

Material examined. -

FMNH 51564; 3 specimens, holotype and paratypes, sl 36-90 mm; East Malaysia: Sabah, Kinabatangan District, Pinang River $\left(05^{\circ} 30^{\prime}\right.$ N. $118^{\circ} 33^{\prime}$ E.); coll. R. F. Inger, 10-V-1950.

FMNH 51660; 2 specimens, paratypes, sl 103-108 mm; East Malaysia. Mixed series: 1 specimen East Coast Residence, coll. R. F. Inger, 29-V-1950; 1 specimen Kinabatangan District, Gaja River, Dewhurst Bay $\left(05^{\circ} 30^{\prime}\right.$ N. $118^{\circ} 33^{\prime}$ E.), coll. R. F. Inger, 14-V-1950.

FMNH 51661; 3 specimens, paratypes, sl 14-33 mm; East Malaysia, East Coast Residence; coll. R. F. Inger, 25-V-1950.

FMNH 51662; 3 specimens, paratypes, sl 36-90 mm; East Malaysia, East Coast Residence; coll. R. F. Inger, 10-VI-1950.

\section{Description of the holotype. -}

General morphology. - Like general description. Head region depressed; lateral line system distinct; spines comparatively big, covering area between eyes and anus.

Colour in alcohol. - All four dorsal marks present. Anteriormost mark length across back $16.7 \mathrm{~mm}$ (5.4 in sl), width $2.7 \mathrm{~mm}$ (3.3 in sl and 6.2 in length); second mark length across back $22 \mathrm{~mm}$ (4.1 in sl), width $6.6 \mathrm{~mm}$ (13.6 in sl and 3.3 in length); third mark length across back 14.5 $\mathrm{mm}(6.2 \mathrm{in} \mathrm{sl})$, width $7.0 \mathrm{~mm}$ (12.9 in sl and 2.1 in length); posteriormost mark length across back $8.0 \mathrm{~mm}$ (11.3 in sl), width $7.5 \mathrm{~mm}$ (12.0 in sl and 1.1 in length); between nostrils only a spot; 15 lateral spots on each side; caudal fin with 5 cross bands made up of points.

Morphometrics. - sl $90 \mathrm{~mm}$; tl $118 \mathrm{~mm}$; dorsal fin rays iii.11, longest ray (the 6th) $13.8 \mathrm{~mm}$ (6.5 in sl), shortest ray (the 1st) $5.0 \mathrm{~mm}$ (18.0 in sl), base $11.8 \mathrm{~mm}$ (7.6 in sl and 1.2 in longest ray); anal fin rays iii.9, longest ray (the 6th) $13.9 \mathrm{~mm}(6.5 \mathrm{in} \mathrm{sl})$, shortest ray (the 1st) $5.9 \mathrm{~mm}(15.2$ in sl), base $9.5 \mathrm{~mm}$ (9.5 in sl and 1.5 in longest ray); pectoral fin rays ii.20, longest ray (the 4th) $14.5 \mathrm{~mm}(6.2$ in sl), shortest ray (the 1st) $6.1 \mathrm{~mm}$ (14.8 in sl), base $11.9 \mathrm{~mm}$ (7.6 in sl and 1.2 in longest ray); depth maximum $44 \mathrm{~mm}$ ( 2.0 in sl), at pectoral fin base $38 \mathrm{~mm}$ (2.4 in sl), at end of dorsal fin base $19.8 \mathrm{~mm}$ (4.6 in sl); width maximum $39 \mathrm{~mm}$ (2.3 in sl and 1.1 in maximum depth), at pectoral fin base $36 \mathrm{~mm}$ (2.5 in sl and 1.1 in corresponding depth), at end of dorsal fin base $16.9 \mathrm{~mm}$ (5.3 in sl and 1.2 in corresponding depth); head length $40 \mathrm{~mm}$ (2.3 in sl); snout length $17.2 \mathrm{~mm}(2.3 \mathrm{in} \mathrm{hl})$; interocular distance $28 \mathrm{~mm}(1.4 \mathrm{in} \mathrm{hl})$; eye horizontal diameter $8.8 \mathrm{~mm}$ (4.5 in $\mathrm{hl})$, distance from dorsal profile $4.0 \mathrm{~mm}$ (10.0 in $\mathrm{hl}$ ); nasal 
organ length $5.4 \mathrm{~mm}$ (7.4 in $\mathrm{hl})$, distance from tip of snout $14.5 \mathrm{~mm}(2.8 \mathrm{in} \mathrm{hl})$, distance from eye $4.7 \mathrm{~mm}$ (8.5 in hl and 3.1 in distance from tip of snout); mouth width $14.5 \mathrm{~mm}$ (2.8 in $\mathrm{hl})$; upper lip depth $2.9 \mathrm{~mm}$ (13.8 in hl); lower lip depth $2.6 \mathrm{~mm}$ (15.4 in $\mathrm{hl})$.

\section{Material examined. -}

FMNH 51564 ex parte; 1 specimen, holotype, $90 \mathrm{~mm}$ sl; East Malaysia: Sabah, Kinabatangan District, Pinang River $\left(05^{\circ} 30^{\prime}\right.$ N. $118^{\circ} 33^{\prime}$ E.); coll. R. F. Inger, 10-V-1950.

Etymology and distribution. - The name sabahensis refers to the impression that the subspecies is geographically confined to Sabah and perhaps to other parts of Borneo.

Tetraodon steindachneri nom. nov.

Figs. 38-40.

\section{Crayracion fluviatilis var. ocellata}

SteindaChNER, 1870: 640, Taf. 5 figs. 2, 2a (original description; lateral and dorsal views figured; Singa- pore: Pengulon Patie; material can not be located at present).

Tetrodon palembangensis;

Fowler, 1934b: 351, fig. 13 (listed; Thailand: Kratt; material in ANSP, reg. no. 60239).

FowLER, 1935: 163 (listed; Thailand: Srisawat; material in ANSP, can not be located at present).

Tetraodon palembangensis;

MEINKEN, 1956: 61-63, fig. p. 61 (description, aquarium data; unde, live imported; material in $\mathrm{ZMH}$, reg. no. 1252).

GroBE, 1956: 111 (aquarium data; no material).

BENL, 1956: 4, 6, 7, 10, Abb. 6 (description, aquarium data; no material).

MERCKENS, 1959: 170 (description, aquarium data; no material).

STERBA, 1959: 640, Taf. 256 (description, aquarium data; no material).

General description. -

General morphology. - Body oblong, slightly compressed laterally; dorsal profile arched, highest at midst of back; interorbital convex, without a groove; lateral line system distinct; body spines small, sometimes partly or wholly indistinct,
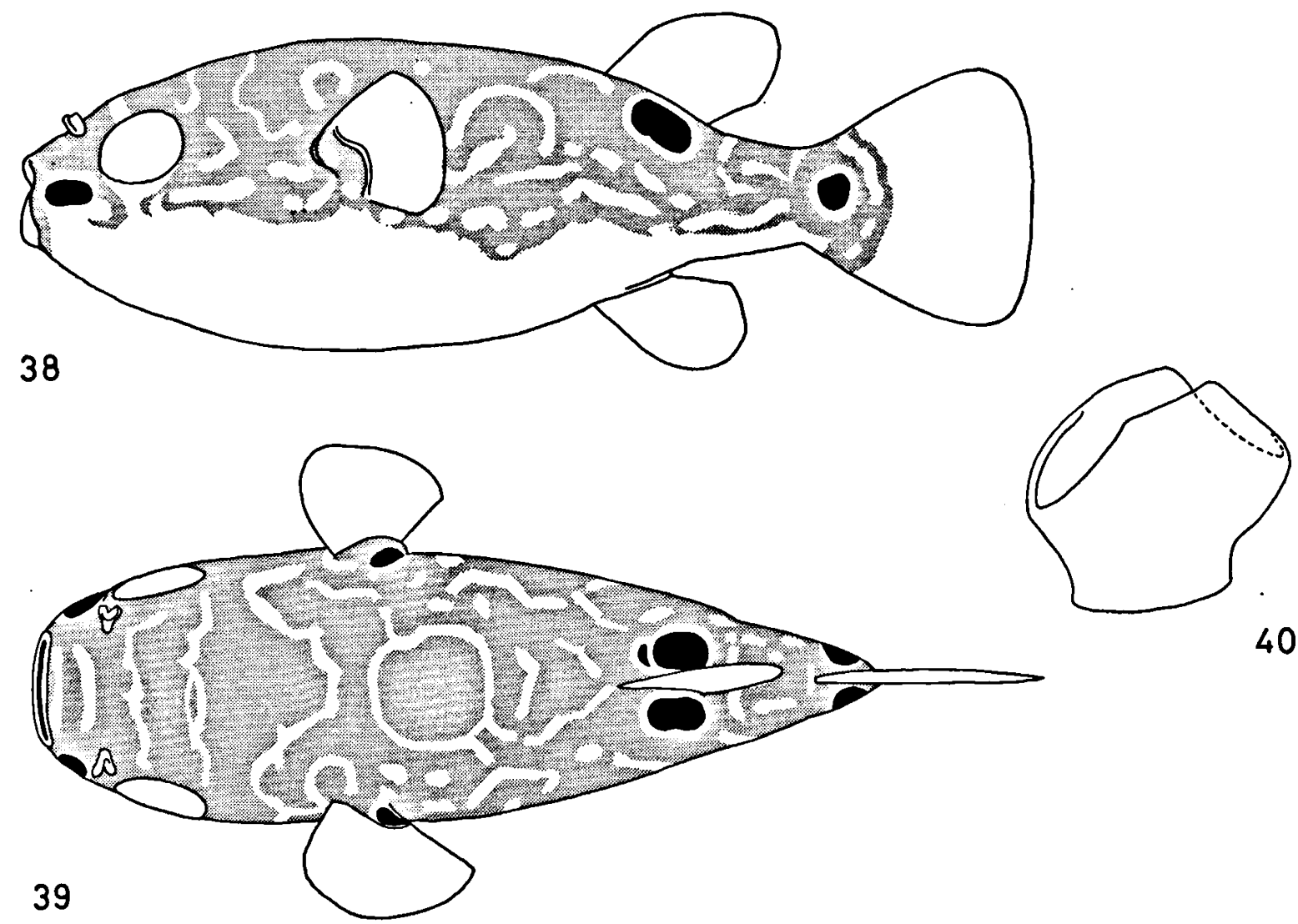

38

Figs. 38-40. Tetraodon steindachneri nom. nov.

Fig. 38. Lateral view of syntype after Steindachner (1870: tab. 5, fig. 2).

Fig. 39. Dorsal view of syntype after Steindachner (1870: tab. 5, fig. 2a).

Fig. 40. Nasal organ of ZMA 112.580, sl $47 \mathrm{~mm}$. 
covering back, sides, and belly between eyes and origin of dorsal fin; origin of anal fin situated beneath anterior half of dorsal fin base; mouth terminal, directed forwards; lower border of eye slightly above level of mouth corner, upper border not interfering with dorsal profile; nasal organ a tentacle, more than distal half of which is divided into two flattened and broadened lobes; apposed surfaces of lobes șmooth.

Colour in alcohol. - Ground colour of upper parts tan, of belly yellowish white; three large yellowish-encircled dark patches on back between eyes and dorsal fin: anterior patch on posterior half of head (length along midline of back 4.4-9.2 in sl and 1.3-2.4 in transversal length), middle patch between pectoral fins (length along midline of back 4.3-5.7 in sl and 0.7-1.1 in transversal length), posterior patch in front of dorsal fin (length along midline of back 5.7-14.8 in sl and 0.6-2.0 in transversal length); sometimes (in 2 out of 7 specimens) a light centre in anterior patch (diameter 12-30 in sl); sometimes (in 1 out of 7 specimens) a light centre in middle patch (diameter 30 in sl); a yellowish band like the ones encircling dorsal patches between nasal organs giving impression of a fourth dark patch between nasal organs and hind border of eyes; sometimes (in 1, the largest out of 7 specimens) 2 more yellowish bands, crossing the snout anterior of nasal organs; sides with similar bands and lines, often bended or broken up in oblong or rounded spots; sides with 2-4 dark ocellated spots: one at base of dorsal fin (always present, the largest), one at base of caudal fin (always present), one at base of pectoral fin (present in 2 out of 7 specimens), one anterior of eyes (present in 5 out of 7 specimens); fins plain except for an ocellus on interior side of pectoral fin base.

Morphometrics (based on 7 specimens). - sl 32-59 (m 42) $\mathrm{mm}$; tl $41-70$ (m 51) $\mathrm{mm}$; dorsal fin rays 13-15 (m 14.0) of which 2-5 (m 2.9) unbranched, longest ray (the 7-10th) 6.3-10.2 (m 7.6) in sl, shortest ray (the 1st) 12.1-24 (m 20) in sl, base 6.5-7.8 (m 7.2) in sl and 0.7-1.1 (m 1.0) in longest ray; anal fin rays $11-13$ (m 12.0) of which 1-2 (m 1.6) unbranched, longest ray (the 7-8th) 6.7-9.8 (m 8.0) in sl, shortest ray (the 1st) $14-23$ (m 18) in $\mathrm{sl}$, base 8.0-9.8 (m 8.9) in sl and 0.8-1.2 (m 1.1) in longest ray; pectoral fin rays $18-21$ (m 19.3) of which 2-3 (m 2.1) unbranched, longest ray (the 5-8th) 7.4-9.8 (m 8.7) in sl, shortest ray (the 1st) 16-27 (m 22) in sl, base 7.7-8.9 (m 8.2) in sl and
0.8-1.2 ( $\mathrm{m} \mathrm{1.0)}$ in longest ray; depth maximum 2.33.3 (m 2.8) in sl, at pectoral fin base 2.4-3.3 (m 2.8) in sl, at end of dorsal fin base 5.5-7.1 (m 6.3) in sl; width maximum 2.6-3.3 (m 2.9) in sl and 1.01.3 in maximum depth, at pectoral fin base 2.63.5 (m 3.1) in sl and 1.0-1.2 (m 1.1) in corresponding depth, at end of dorsal fin base 6.4-9.0 (m 7.3) in sl and 1.1-1.3 (m 1.2) in corresponding depth; head length 2.3-2.5 (m 2.4) in sl; snout length 2.4-2.9 (m 2.8) in hl; interocular distance 1.7-2.0 (m 1.8) in hl; eye horizontal diameter 2.9-3.9 (m 3.3) in hl, distance from dorsal profile 7.4-25 (m 13.8) in $\mathrm{hl}$; nasal organ length 7.6-13.3 (m 9.8) in $\mathrm{hl}$, distance from tip of snout 3.1-3.9 (m 3.5) in hl, distance from eye 7.5-14.3 (m 11.3) in $\mathrm{hl}$ and 2.44.3 (m 3.2) in distance from tip of snout; mouth width 2.9-3.9 (m 3.4) in hl; upper lip depth 9.115.5 (m 12.2) in hl; lower lip depth 8.7-24 (m 16.7) in $\mathrm{hl}$.

Material examined. -

ANSP 60239; 1 specimen, sl $32 \mathrm{~mm}$; Thailand: Kratt; coll. R. M. de Schauensee of the Third De Schauensee Siamese Expedition, XII-1933.

RMNH 15306; 3 specimens, sl 35-46 mm; Indonesia: Borneo, Samarinda; coll. Witkamp, 29-III-1931; ex LOZB.

ZMA 112.580; 1 specimen, sl $47 \mathrm{~mm}$; unde, imported alive; died at NAM, 1965.

ZMH 1252; 2 specimens, sl 34-59 mm; unde, imported alive; donation Meinken, 1960.

\section{Description of the syntypes. -}

The first description of $T$. steindachneri was made by Steindachner (1870). The description was based on 4 specimens. These syntypes are most probably present in NMW, but they can not be located there at the moment (Kähsbauer, in lit., 1971). It is possible that Steindachner returned the specimens to the collector, Ransonnet, and that from there they went elsewhere. Anyway, the syntypes can not be located, but there is no proof that they are lost. So, a neotype can not be selected from other material. Confusion, however, will not arise because of the excellent illustrations by Steindachner, which are reproduced hereby in adapted form (figs. 38-39).

Distribution. - T. steindachneri is known only from West Malaysia (including Singapore), Thailand and Borneo. The specimens described by Meinken (1956) were said to have been collected in Sumatra. This locality was considered in the publication as doubtful, because the specimens were imported by aquarium trade from Penang. 
Etymology. - Both names under which the species has been known until now are invalid. The name $T$. palembangensis belongs to a distinctly different species. The name Crayracion fluviatilis var. ocellata is subject to the rules of the International Code of Zoological Nomenclature as Steindachner is considered to have described a subspecies (art. 45d-i). After being elevated to species rank and being placed in the genus Tetraodon by me, the name becomes a junior secondary homonym of Tetraodon ocellatus Linnaeus, 1758, (art. 57) and must be rejected and replaced (art. 53) even though the Linnaean species is at the moment generally believed to belong to a different genus, Sphoeroides or Torquigener. An additional reason to rename the species, not prescribed by the Code, is to avoid confusion with the name $T$. ocellaris Klausewitz, 1957. I renamed the species in honour of the first author to recognize it as distinct from typical fluviatilis.

\section{w a a nd e r s i i -group}

Diagnosis. - Tetraodon species with about 35 dark transverse bandelets on upper half of body; D 12; A 11; P 16. One species: T. waandersii.

Discussion. - $T$. waandersii was originally described by Bleeker in 1853 from a single specimen, type locality Bangka Island, Marawang, fresh water. No specimen was recorded ever since, so there is every reason to check the validity of the species.

A great problem in studying the unique specimen is the poor state of the nasal organs, as no generic allocation can be based anymore on this character. In literature there is confusion about the organ. The original description (Bleeker, 1853b: 194) states: "papilla nasali utroque latere simplice indivisa oblonga" but in his emended description of 1865a (: 77) Bleeker says: "Ces organes, en effet, ont la forme en entonnoir non perforé et à bord libre fimbrié comme le Leiodon patoca". The latter statement would imply that the species belongs to the patoca-group, often considered a separate subgenus or genus named Chelonodon.

Regan (1902: 302-303), however, synonymized $T$. waandersii with $T$. fluviatilis Hamilton, 1822 , stating that "The supposed difference in the nasal organs is non-existent, they might impartially be described either as a short tube with two terminal lips, or as two tentacles united basally, although the former phrase is more applicable to the smaller specimens, the latter to the larger...". In this statement Regan misses the point: in the first place he is obviously describing the nasal organs of $T$.fluviatilis (he uses the plural form: specimens), in the second place there was no problem in the nasal organs being splitted only terminally or to the base, but in being patoca-like or not.

A last clue to the form of the nasal organ could be the figure in the Atlas Ichthyologique. This shows the nasal organ possessing five flaps, but it is not obvious whether these represent only one or both of the nasal organs, although in the other figures of Tetraodon species only one nasal organ is shown. $T$. patoca in general only possesses two flaps. Most probably the figure is not correct in this aspect.

Concluding we can say that the form of the nasal organ is not known. Probably Bleeker, in his emended description, was right and the species is close to $T$. patoca. The latter possesses a totally different colour pattern, consisting mainly of oval whitish spots on the upper half of the body, never possessing the dark transverse bandelets like in Sphoeroidesoblongus, even not in young specimens. It is, however, known that $T$. patoca is very variable in some characteristics, hence the great number of allied species described. This is understandable of a species having the widest distribution area of all freshwater tetraodonts.

I consider it the best to await new material from the Bangka Island before deciding on the affinities of $T$. waandersii, listing it in a group of its own. The only other true Tetraodon known from the Bangka Island is $T$. nigroviridis, a completely differently coloured species.

A strong argument for $T$. waandersii being a young of $T$. patoca is the number of $P$ rays: 16 (not 11 as stated by Bleeker) as the pectoral fin ray counts of $T$. patoca vary according to De Beaufort (1962) from 15 to 16 , a number which is unknown in Indonesian Tetraodon species.

Tetraodon waandersii Bleeker, 1853.

Figs. 41-42.

Tetraödon Waandersii

BLEEKER, 1853b: 176, 182, 194 (original description; Indonesia: Bangka Island, Marawang; material in BMNH, reg. no. 1867.11.28: 112, holotype).

Rohita Waandersii;

BLEEKER, 1853b: 185 (name misprinted).

Arothron Waandersii;

BLEEKER, 1854d: 260 (listed; no additional material). 
BLEEKER, 1859a: 202 (listed; no additional material). BLEEKER, 1859b: 374 (listed; no additional material). Leiodon Waandersii;

BLEEKER, 1865a: 76-77, tab. 214 fig. 3 (emendated description; no additional material).

BLEEKER, 1866a: 38 (listed; no additional material).

Tetrodon waandersii;

GüNTHER, 1870: 289 (description; no additional material) (in subgenus Chelonodon).

WEBER, 1894: 458 (listed; no additional material).

Tetrodon fluviatilis;

REGAN, 1902: 302-303 (in part) (comparison of holotype of $T$. waandersii with young specimens of $T$. fluviatilis sensu lato; no additional material).

Tetraodon fluviatilis;

DE BEAUFORT, 1962: 395-397 (in part) (listed in synonymy, probably after Regan, 1902; no additional material).

\section{Description of the holotype. -}

Recognition. - In all publications by Bleeker only one specimen is recorded; no further specimens were recorded ever since. So, the specimen recorded by Günther (1870: 289) as "Type of the species" must indeed be the holotype. The correctness of this view may be underlined by the fact that the catalogue of the auction of the Bleeker Collection does not mention the species, apparently because the specimen was already incorporated in the collections of BMNH.

General morphology. - Body oblong; dorsal profile of head rounded; interorbital convex, without a groove; lateral line system indistinct; spines on back, sides and belly, from eyes to near origin of dorsal fin; origin of anal fin beneath anterior half of dorsal fin base; for form of nasal organ see waandersii-group.
Colour in alcohol. - Ground colour of upper parts tan, of belly yellowish; about 35 transverse dark bandelets on upper half of body from snout to caudal peduncle (still visible at present), a few of which have their ends branched or mutually united; fins plain, caudal fin darkest.

Morphometrics. - tl $45 \mathrm{~mm}$ (41 mm at present); caudal fin length 5 in tl, so sl was $36 \mathrm{~mm}(35 \mathrm{~mm}$ at present); dorsal fin rays ii.10, longest ray longer than base; anal fin rays ii.9, longest ray longer than base; pectoral fin rays ii.14 (original description: i.10); depth maximum 4 in tl, so $11 \mathrm{~mm}$ (3.3 in sl); front part of body as deep as wide, so width maximum about $11 \mathrm{~mm}$ (3.3 in sl); head length 3.3 in $\mathrm{t}$, so $13.6 \mathrm{~mm}$ (2.6 in sl); eye diameter $3.3 \mathrm{in} \mathrm{hl}$, so $4.1 \mathrm{~mm}$.

\section{Material examined. -}

BMNH 1867.11.28: 112; 1 specimen, sl $36 \mathrm{~mm}$, holotype (sl $35 \mathrm{~mm}$ at present); Indonesia: Sumatra, Bangka Island, Marawang, fresh water; coll. H. L. van Bloemen Waanders, about 1853; presented to Bleeker about 1853).

Note. - Due to the bad state of preservation of the unique specimen the description was made also using the descriptions and the figure provided by Bleeker $(1853 b, 1865 a)$.

Distribution. - The species is known only from Indonesia: Sumatra, Bangka Island, from fresh water.

Etymology. - The species is named in honour of the collector, H. L. van Bloemen Waanders.

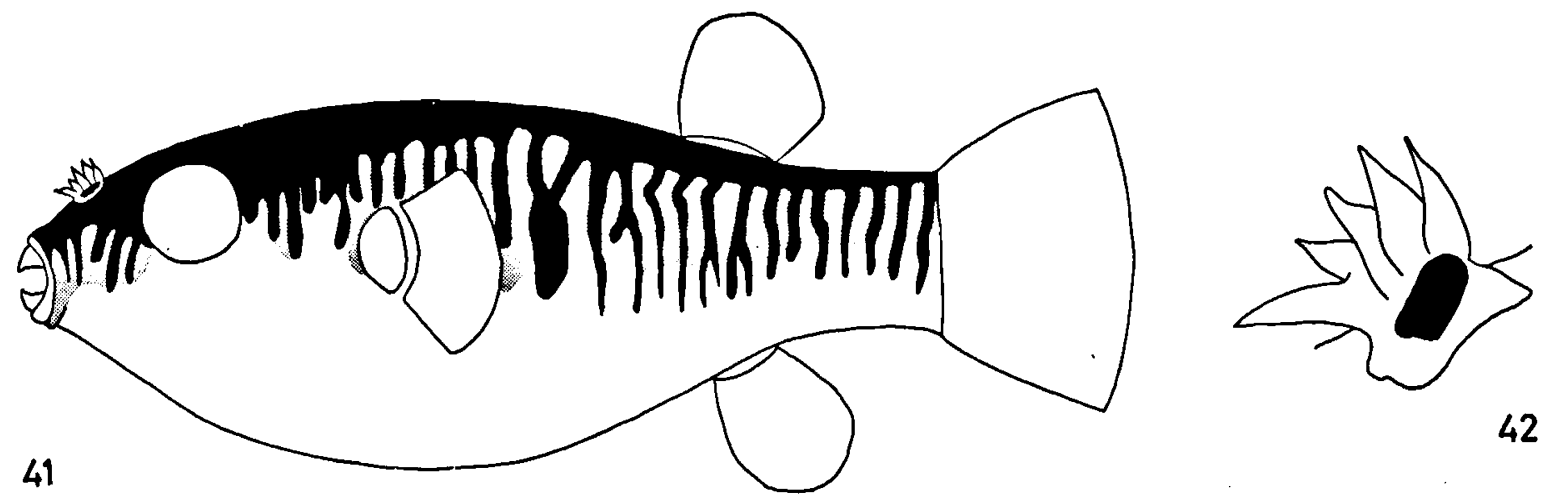

Figs. 41-42. Tetraodon waandersii Bleeker, 1853.

Fig. 41. Lateral view of BMNH 1867.11.28: 112, holotype, sl $36 \mathrm{~mm}$; after Bleeker (1865a: tab. 214, fig. 3).

Fig. 42. Lateral view of nasal organ(s) of BMNH 1867.11.28: 112, holotype, sl $36 \mathrm{~mm}$; after Bleeker (1865a: tab. 214, fig. 3). 


\section{REFERENCES}

ABE, T., 1949. Taxonomic studies on the puffers (Tetraodontidae, Teleostei) from Japan and adjacent regions. V. Synopsis of the puffers from Japan and adjacent regions. Bull. biogeogr. Soc. Japan, 14 (13): 89-140, pls. $1-2$.

Abreu, E. A. D', 1925. A list of fishes obtained in the Saran District, Behar, chiefly from the Ghogra River near the town of Chapra and in its vicinity. J. Bombay nat. Hist. Soc., 30 (3-4): 707-711.

AnNandale, N. \& J. T. Jenkins, 1910. Report on the fishes taken by the Bengal Fisheries Steamer "Golden Crown". Part III. Plectognathi and Pediculati. Mem. Indian Mus., 3 (1): 7-21, pls. 1-2.

Aubenton, F. D' \& M. Blanc, 1966. Poissons tétraodontiformes du Cambodge. Bull. Mus. natn. Hist. nat. Paris, (2) 38 (5): 554-561, figs. $1-4$.

AXelrod, H. R., C. W. Emmens, D. Sculthorpe, W. VorderWINKLER \& N. ProneK, 1967. Exotic tropical fishes: $M$ 3.00-M 121.00, P 2.00-P 93.00, C 3.00C 48.00 , F $1.00-F \quad 608.00$, ca. 900 figs. (T. F. H. Publications, Jersey City).

Bean, B. A. \& A. C. WeEd, 1912. Notes on a collection of fishes from Java, made by Owen Bryant and William Palmer in 1909, with description of a new species. Proc. U.S. natn. Mus., 42 (1919): 587-611, figs. $1-3$, pls. $73-75$.

Beaufort, L. F. DE, 1913. Fishes of the eastern part of the Indo-Australian Archipelago with remarks on its zoogeography. Bijdr. Dierk., 19: 95-164, figs. $1-8$, pl. 2.

-, 1926. Zoögeographie van den Indischen Archipel: 1-202, figs. 1-8, 1 map (Erven Bohn, Haarlem).

,- 1939 . On a collection of freshwater fishes of the island of Billiton. Treubia, 17 (3): 189-198, 1 fig.

,- 1951 . Zoogeography of the land and inland waters: i-viii, 1-208, figs. 1-10 (Taylor \& Francis, London).

,- 1962 . The fishes of the Indo-Australian Archipelago. XI. Scleroparei, Hypostomides, Pediculati, Plectognathi, Opisthomi, Discocephali, Xenopterygii: i-xi, 1-481, figs. 1-100 (Brill, Leiden).

-.1964. Bleeker's collection in the Zoological Museum of Amsterdam. Beaufortia, 11 (131): 23-25.

BECK, P., 1950. Traité complet de la vie des animaux en aquarium: 1-269, figs. 1-103 (Payot, Paris).

BENL, G., 1956. Süsswasser-Kugelfische. Aquar. - u. Terrar.-Z., $9(6,7,8): 141-147,172-175,202-$ 205, Abb. 1-14.

- , 1957a. Tetraodon leiurus brevirostris, subsp. nova. Aquar.- u. Terrar.-Z., 9: 63-65, Abb. 1-4.

-, 1957b. Carinotetraodon chlupatyi nov. gen., nov. spec., ein Kugelfisch mit Kamm und Kiel (Pisces, Fam. Tetraodontidae). Opusc. zool. Münch., 5: 1-4, 1 fig.

-, 1959. Zur Nomenklatur Siamesischer Kugelfischformen. Aquar.- u. Terrar.-Z., 12 (2): $42-44$.

Benl, G. \& P. Chlupaty, 1957. Carinotetraodon, eine neue Kugelfischgattung. Aquar.- u. Terrar.-Z., 10 (9): 227-229, Abb. 1-2.

BleEker, P., 1849a. Bijdrage tot de kennis der ichthyologische fauna van het eiland Madura, met beschrijving van eenige nieuwe soorten. Verh. batav. Genoot. Kunst. Wet., 22 (7): 1-16. -,1849b. Bijdrage tot de kennis der ichthyologische fauna van Midden- en Oost-Java, met beschrijving van eenige nieuwe species. Verh. batav. Genoot. Kunst. Wet., 23 (12): 1-23.

-, 1851a. Bijdrage tot de kennis der ichthyologische fauna van Borneo met beschrijving van 16 nieuwe soorten van zoetwatervisschen. Natuurk. Tijdschr. Ned.-Indië, 1: 1-16.

,$- 1851 \mathrm{~b}$. Bijdrage tot de kennis der ichthyologische fauna van Riouw. Natuurk. Tijdschr. Ned.-Indië, 2: 469-497.

-, 1851c. Derde bijdrage tot de kennis der ichthyologische fauna van Borneo met beschrijving van eenige nieuwe soorten van zoetwatervisschen. Natuurk. Tijdschr. Ned.-Indië, 2: 57-70.

- , 1851d. Nieuwe bijdrage tot de kennis der ichthyologische fauna van Borneo met beschrijving van eenige nieuwe soorten van zoetwatervisschen. Natuurk. Tijdschr. Ned.-Indië, 1: 259-275.

- , 1851e. Over drie nieuwe soorten van Tetraödon van den Indischen Archipel. Natuurk. Tijdschr. Ned.-Indië, 1: 96-97.

-, 1851f. Vierde bijdrage tot de kennis der ichthyologische fauna van Borneo met beschrijving van eenige nieuwe soorten van zoetwatervisschen. Natuurk. Tijdschr. Ned.-Indië, 2: 193-208.

-, 1851g. Vijfde bijdrage tot de kennis der ichthyologische fauna van Borneo met beschrijving van eenige nieuwe soorten van zoetwatervisschen. Natuurk. Tijdschr. Ned.-Indië, 2: 415-442.

,- 1852 a. Bijdrage tot de kennis der blootkakige visschen van den Soenda-Molukschen Archipel met beschrijving van eenige nieuwe soorten. Verh. batav. Genoot. Kunst. Wet., 24 (10): 1-26.

,- 1852 b. Bijdrage tot de kennis der ichthyologische fauna van Singapore. Natuurk. Tijdschr. Ned.-Indië, 3: $51-86$.

-, 1852c. Diagnostische beschrijvingen van nieuwe of weinig bekende vischsoorten van Sumatra. Tiental I-IV. Natuurk. Tijdschr. Ned.-Indië, 3: 569-608.

$\rightarrow$ 1852d. Zesde bijdrage tot de kennis der ichthyologische fauna van Borneo. Visschen van Pamangkat, Bandjermassing, Praboekarta en Sampit. Natuurk. Tijdschr. Ned.-Indië, 3: 407-442.

-, 1853a. Nalezingen op de ichthyologische fauna van Bengalen en Hindostan. Verh. batav. Genoot. Kunst. Wet., 25 (8): 1-164, tabul. 1-6.

-, 1853b. Nalezingen op de ichthyologische fauna van het eiland Banka. Natuurk. Tijdschr. Ned.-Indië, 5: 175-194.

-, 1853c. Vierde bijdrage tot de kennis der ichthyologische fauna van Amboina. Natuurk. Tijdschr. Ned.Indië, 5: $317-352$.

-, 1853d. Vierde bijdrage tot de kennis der ichthyologische fauna van Celebes. Natuurk. Tijdschr. Ned.-Indië, 5: $153-174$.

- , 1853e. Zevende bijdrage tot de kennis der ichthyologische fauna van Borneo. Zoetwatervisschen van Sambas, Pontianak en Pangaron. Natuurk. Tijdschr. Ned.Indië, 5: $427-462$.

,$- 1854 \mathrm{a}$. Ichthyologische waarnemingen, gedaan op verschillende reizen in de residentie Bantam. Natuurk. Tijdschr. Ned.-Indië, 7: 309-326. 
,$- 1854 b$. Overzigt der ichthyologische fauna van Sumatra, met beschrijving van eenige nieuwe soorten. $\mathrm{Na}$ tuurk. Tijdschr. Ned.-Indië, 7: 49-108.

,$- 1854 \mathrm{c}$. Vijfde bijdrage tot de kennis der ichthyologische fauna van Amboina. Natuurk. Tijdschr. Ned.Indië, 6: 455-508.

,$- 1854 \mathrm{~d}$. Vijfde bijdrage tot de kennis der ichthyologische fauna van Celebes. Natuurk. Tijdschr. Ned.Indië, 7: 225-260.

-, 1855a. Achtste bijdrage tot de kennis der ichthyologische fauna van Borneo. Zoetwatervisschen van Bandjermasin. Natuurk. Tijdschr. Ned.-Indië, 8: 151168.

,- 1855 b. Achtste bijdrage tot de kennis der ichthyologische fauna van Celebes. Natuurk. Tijdschr. Ned.Indië, 9: 281-314.

-, 1855c. Nalezingen op de vischfauna van Sumatra. Visschen van Lahat en Sibogha. Natuurk. Tijdschr. Ned.-Indië, 9: 257-280.

-, 1855d. Negende bijdrage tot de kennis der ichthyologische fauna van Borneo. Zoetwatervisschen van Pontianak en Bandjermasin. Natuurk. Tijdschr. Ned.Indië, 9: $415-430$.

-, 1855e. Zesde bijdrage tot de kennis der ichthyologische fauna van Amboina. Natuurk. Tijdschr. Ned.Indië, 8: $391-434$.

,- 1856 a. Beschrijvingen van nieuwe en weinig bekende vischsoorten van Amboina, verzameld op eene reis door den Molukschen Archipel gedaan in het gevolg van den Gouverneur-Generaal Duymaer van Twist, in September en Oktober 1855. Verh. natuurk. Ver. Ned.-Indië, 1 (5): $1-76$.

-, 1856b. Beschrijvingen van nieuwe of weinig bekende vischsoorten van Manado en Makassar, grootendeels verzameld op eene reis naar den Molukschen Archipel in het gevolg van den Gouverneur-Generaal Duymaer van Twist. Verh. natuurk. Ver. Ned.-Indië, 1 (6): $1-80$.

,$- 1856 \mathrm{c}$. Verslag van eenige verzamelingen van zee- en zoetwatervisschen van het eiland Banka. Natuurk. Tijdschr. Ned.-Indië, 11: 415-420.

,- 1857 a. Achtste bijdrage tot de kennis der vischfauna van Amboina. Verh. natuurk. Ver. Ned. Ind., 2 (7): $1-102$.

$\rightarrow$ 1857b. Conspectus specierum piscium moluccensium hucusque cognitarum. Verh. natuurk. Ver. Ned. Ind., 2 (4): $1-23$.

- , 1857c. Tiende bijdrage tot de kennis der ichthyologische fauna van Borneo. Visschen van de rivieren Barito, Kahajan en Kapoeas. Verh. natuurk. Ver. Ned. Ind., 2 (6): $1-21$.

-, 1858a. Zesde bijdrage tot de kennis der vischfauna van Sumatra. Visschen van Padang, Troessan, Priaman, Sibogha en Palembang. Verh. natuurk. Ver. Ned. Ind., 3 (9): $1-50$.

-, 1858b. Elfde bijdrage tot de kennis der ichthyologische fauna van Borneo. Visschen van Sinkawang. Verh. natuurk. Ver. Ned. Ind., 3 (13): 1-4.

-, 1858c. Enumeratio specierum piscium javanensium hucusque cognitarum. Natuurk. Tijdschr. Ned.-Indië, 15: $359-456$.

-, 1858d. Tweede bijdrage tot de kennis der vischfauna van Singapore. Natuurk. Tijdschr. Ned.-Indië, 15: $241-254$.

,- 1859 a. Enumeratio specierum piscium hucusque in
Archipelago Indico observatarum, adjectis habitationibus citationibusque, ubi descriptiones earum recentiores reperiuntur, nec non speciebus musei Bleekeriani Bengalensibus, Japonicis, Capensibus Tasmanicisque: ixxxvi, 1-276 (Langii \& Soc., Batavia (= Djakarta)).

,- 1859 b. Negende bijdrage tot de kennis der vischfauna van Banka. Natuurk. Tijdschr. Ned.-Indië, 18: 359-378.

,- 1859 c. Twaalfde bijdrage tot de kennis der vischfauna van Borneo. Visschen van Sinkawang. Verh. natuurk. Ver. Ned. Ind., 5 (7): 1-10.

,- 1859 d. Verslag van eene verzameling visschen van westelijk Borneo, aangeboden door J. H. A. Sonneman Rebentisch. Natuurk. Tijdschr. Ned.-Indië, 16: 433436.

- 1859e. Vischsoorten, toegezonden van Banjoewangi door den heer Zollinger, eenige andere, verzameld te Buitenzorg door den heer $\mathbf{H}$. Von Rosenberg. Natuurk. Tijdschr. Ned.-Indië, 16: $47-48$.

-, 1859f. Vischsoorten van Palembang, verzameld door E. A. Lange en F. J. P. Storm van 's-Gravensande. Natuurk. Tijdschr. Ned.-Indië, 16: 263-266.

- $1859 \mathrm{~g}$. Vischsoorten van Palembang, verzameld door R. V. Heyliger. Natuurk. Tijdschr. Ned.-Indië, 16: 338-341.

-, 1859h. Zevende bijdrage tot de kennis der vischfauna van Sumatra. Visschen van Palembang. Verh. natuurk. Ver. Ned. Ind., $5(6): 1-12$.

-, 1860a. Achtste bijdrage tot de kennis der vischfauna van Sumatra. (Visschen van Benkoelen, Priaman, Tandjong, Palembang en Djambi). Verh. natuurk. Ver. Ned.-Indië, 8 (2): $1-88$.

-, 1860b. Derde bijdrage tot de kennis der vischfauna van Singapoera. Natuurk. Tijdschr. Ned.-Indië, 20: $446-456$.

-, 1860c. Dertiende bijdrage tot de kennis der vischfauna van Borneo. Verh. natuurk. Ver. Ned.-Indië, 8 (4): $1-64$.

-, 1860d. Dertiende bijdrage tot de kennis der vischfauna van Celebes. (Visschen van Bonthain, Badjoa, Sindjai, Lagoesi en Pompenoea). Verh. natuurk. Ver. Ned.-Indië, 8 (7): $1-60$.

,- 1860 e. Negende bijdrage tot de kennis der vischfauna van Sumatra. (Visschen uit de Lematang-Enim en van Benkoelen). Verh. natuurk. Ver. Ned.-Indië, 8 (3): $1-12$.

,$- 1860 f$. Nieuwe vischsoorten van Singapore, verzameld door Fr. Graaf de Castelnau. Natuurk. Tijdschr. Ned.Indië, 20: 236-239.

,- 1860 g. Zoetwatervisschen van Sintang, verzameld door den heer A. Thepass. Natuurk. Tijdschr. Ned.-Indië, 20: $199-200$.

,- 1861a. Iets over de vischfauna van het eiland Pinang. Versl. Meded. K. Akad. Wet. Amst., 12: 64-80.

-, 1861b. Mededeeling omtrent vischsoorten, nieuw voor de kennis der fauna van Singapoera. Versl. Meded. K. Akad. Wet. Amst., 12: 28-63.

一, 1861c. Vischsoorten, nieuw voor de kennis der fauna van Singapoera, verzameld door Fr. Graaf de Castelnau. Natuurk. Tijdschr. Ned.-Indië, 22: 101102.

,- 1863 . Over eenige vischsoorten van het eiland Bangka, het Rijks Museum van Natuurlijke Historie te Leiden aangeboden, door den heer J. F. R. S. van den Bossche, Resident. Ned. Tijdschr. Dierk., 1: 72-73. 
-, 1864. Notice sur la faune ichthyologique de Siam. Versl. Meded. K. Akad. Wet. Amst., 16: 352-358.

,$- 1865 a$. Atlas ichthyologique des Indes Orientales Néêrlandaises, publié sous les auspices du gouvernement colonial Néêrlandais. Tome V. Baudroies, Ostracions, Gymnodontes, Balistes: $1-152$, pls. 194-231 (Fréderic Muller, Amsterdam).

-, 1865b. Enumération des espèces de poissons actuellement connues de l'île d'Amboine. Ned. Tijdschr. Dierk., 2: 270-297.

,$- 1865 \mathrm{c}$. Nouvelle notice sur la faune ichthyologique de Siam. Ned. Tijdschr. Dierk., 2: 33-37.

,$- 1865 \mathrm{~d}$. Sixième notice sur la faune ichthyologique de Siam. Ned. Tijdschr. Dierk., 2: 171-176.

-, 1866. Synonyma Balistidorum, Ostracionidorum Gymnodontidorumque Indo-archipelagicorum hucusque observatorum revisa, adjectis habitationibus citationibusque ubi descriptiones figuraeque eorum recentiores reperiuntur. Ned. Tijdschr. Dierk., 3: 20-40.

-, 1868a. Notice sur la faune ichthyologique de l'île de Guébé. Versl. Meded. K. Akad. Wet. Amst., (2) 2: 271-272.

,$- 1868 \mathrm{~b}$. Sixième notice sur la faune ichthyologique de l'île de Bintang. Versl. Meded. K. Akad. Wet. Amst., (2) 2: 289-294.

BLYTH, E., 1860. Report on some fishes recieved chiefly from the Sitang River and its tributary streams, Tenasserim Provinces. J. Asiat. Soc. Beng., 29: 138174.

Boeseman, M., 1957. On a collection of East Asian fishes. Zoöl. Meded. Leiden, 35 (7): 69-79.

-, 1972. Preface. In: W. H. Lamme ed., Pieter Bleeker. Bijdragen tot de ichthyologie van de Indonesische archipel, verzameld en bewerkt uit het Natuurkundig Tijdschrift voor Nederlandsch-Indië I-XXII, 18511861. I: v-viii (Asher \& Co, Vaals/Amsterdam).

Breder, C. H. \& E. Clark, 1947. A contribution to the visceral anatomy, development and relationships of the Plectognathi. Bull. Am. Mus. nat. Hist., 88 (5): $287-320$, figs. $1-8$, pls. $11-14$.

Cantor, T., 1849. Catalogue of Malayan fishes. J. Asiat. Soc. Beng., 18: i-xii, 983-1443, pls. 1-14.

Chabanaud, P., 1923. Description d'un Tetrodon nouveau du Cambodge. Bull. Mus. natn. Hist. nat. Paris, 29 (2): 137-140.

CheveY, P., 1932. Inventaire de la faune ichthyologique de l'Indochine. Deuxième liste. Note Inst. océanogr. Indoch., 19: 1-31.

-, 1936. Le Grand Lac du Cambodge: les causes profondes de sa richesse ichthyologique. Note Inst. océanogr. Indoch., 29: 39-49, figs. 1-3.

Chevey, P. \& F. Le Poulain, 1940. La pêche dans les eaux douces du Cambodge. Trav. Inst. océanogr. Indoch., 5: $1-78$, pls. $1-68$, maps $1-7$, figs. $1-119$.

Chlupaty, P., 1955. Haltung und Pflege von Kugelfischen. Aquar.- u. Terrar.-Z., 8 (8): 197-200.

DAY, F., 1865. On the fishes of Cochin, on the Malabar Coast of India. Part. II. Anacanthini. Proc. zool. Soc. Lond., 1865: 286-318, 8 figs.

,$- 1878-88$. The fishes of India; being a natural history of the fishes known to inhabit the seas and fresh waters of India, Burma, and Ceylon: $\mathrm{i}-\mathrm{xx}, 1-778$, pls. 1-198 (privately printed, London).

,- 1889 . The fauna of British India, including Ceylon and Burma. Published under the authority of the
Secretary of State for India in Council. Edited by W. T. Blanford. Fishes. - Vol. II: i-xiv, 1-509, figs. 1-177. (Taylor \& Francis, London, etc.).

Delsman, H. C. \& J. D. F. Hardenberg, 1934. De Indische zeevisschen en zeevisscherij. Bibliotheek van de Nederlandsch-Indische Natuurhistorische Vereeniging, 6: i-viii, 1-388, figs. 1-273, 1 pl. (Visser \& Co., Batavia).

DumÉril, A. H. A., 1855. Note sur un travail inédit de Bibron relatif aux poissons Plectognathes Gymnodontes (Diodons et Tétrodons). Revue Mag. Zool., (2) 7: $274-282$.

Duncker, G., 1904. Die Fische der Malayischen Halbinsel. Mitt. naturh. Mus. Hamb., 21 (2): 133-207, fig. 1, Taf. 1-2.

-, 1912. Die Süsswasserfische Ceylons. Mitt. naturh. Mus. Hamb., 29 (2): 241-272, 1 map, 1 pl.

DuNCKER, G. \& E. MoHr, 1929. Die Fische der SüdseeExpedition der Hamburgischen Wissenschaftlichen Stiftung 1908-1909. Mitt. zool. St. Inst. Hamb., 44: $57-84$, figs. $1-9$.

Feigs, G., 1955. Fresh-water puffers spawn. Aquarium, Philad., 24 (22): 373-374, 2 figs.

Fowler, H. W., 1905. Some fishes from Borneo. Proc. Acad. nat. Sci. Philad., 57: 455-523, figs. 1-16.

- , 1928. The fishes of Oceania. Mem. Bernice P. Bishop Mus., 10: i-iii, $1-540$, figs. $1-82$, pls. $1-49$.

-, 1934a. Zoological results of the Third De Schauensee Siamese Expedition. Part 1. Fishes. Proc. Acad. nat. Sci. Philad., 86: 67-163, figs. 1-127, pl. 12.

-, 1934b. Zoological results of the Third De Schauensee Siamese Expedition. Part V. Additional fishes. Proc. Acad. nat. Sci. Philad., 86: 335-352, figs. 1-13.

-, 1935. Zoological results of the Third De Schauensee Siamese Expedition. Part VI. Fishes obtained in 1934. Proc. Acad. nat. Sci. Philad., 87: 89-163, figs. 1132.

-, 1937. Zoological results of the Third De Schauensee Siamese Expedition. Part VIII. Fishes obtained in 1936. Proc. Acad. nat. Sci. Philad., 89: 125-264, figs. $1-300$.

- , 1938. A list of the fishes known from Malaya. Fish. Bull. Singapore, 1: 1-268, i-lvi.

Fraser-BrunNer, A., 1940. Notes on the Plectognath Fishes. IV. Sexual dimorphism in the family Ostraciodontidae. Ann. Mag. nat. Hist., (11) 6: 390-392, 1 fig.

- , 1943. Notes on the Plectognath fishes. VIII. The classification of the suborder Tetraodontoidea, with a synopsis of the genera. Ann. Mag. nat. Hist., (11) 10: $1-18$, figs. $1-4$.

Geiser, W., 1958. Aufzucht von Tetraodon leiurus brevirostris. Aquar.- u. Terrar.-Z., 11 (4): 100-101, 1 fig.

GiLl, T., 1892. Notes on the Tetraodontoidea. Proc. U.S. Natn. Mus., 14: 705-720, pl. 34.

Grobe, J., 1956. Tetraodon palembangensis. Aquar.- u. Terrar.-Z., 9 (4): 111.

GudGER, E. W., 1924. The sources of the material for Hamilton-Buchanan's Fishes of the Ganges, the fate of his collections, drawings and notes, and the use made of his data. J. Proc. Asiat. Soc. Beng., 19 (4): $121-136$.

GÜNTHER, A., 1870. Catalogue of the fishes in the British Museum. Vol. 8. Catalogue of the Physostomi, containing the families Gymnotidae, Symbranchidae, 
Muraenidae, Pegasidae, and of the Lophobranchii, Plectognathi, Dipnoi, Ganoidei, Chondropterygii, Cyclostomata, Leptocardii, in the British Museum: $i-x x v$, 1-549 (Trustees Brit. Mus., London).

Hamilton, F., 1822. An account of the fishes found in the river Ganges and its branches: i-vii, $1-405$, pls. 139 (A. Constable \& Co, Edinburgh/Hurst, Robinson \& $\mathrm{Co}$, London).

HARDENBERG, J. D. F., 1931. The fishfauna of the Rokan mouth. Treubia, 13 (1): 81-168, fig. 1, 1 map.

- 1934. Additional notes to my paper "The fishfauna of the Rokan mouth". Treubia, 14 (3): 299-312, figs. $1-4$.

,- 1935 . On a collection of fishes from Samarinda. Natuurk. Tijdschr. Ned.-Indië, 95 (3): 231-239.

- , 1936. On a collection of fishes from the estuary and the lower and middle course of the river Kapuas (W. Borneo). Treubia, 15 (3): 225-254.

,- 1937 . Hydrological and ichthyological observations in the mouth of the Kumai-River (S. W. Borneo). Treubia, 16 (1): 1-14, fig. 1.

Herre, A. W. C. T., 1924. Poisonous and worthless fishes; an account of the Philippine plectognaths. Philipp. J. Sci., 25 (4): 415-510, pls. 1-2.

-, 1933. A check list of fishes from Sandakan, British North Borneo. J. pan-Pacif. Res. Instn, 8 (4): 2-5.

,- 1940 . On a collection of littoral and freshwater fishes from the Andaman Islands: supplement. Rec. Indian Mus., 42: 1-8.

-, 1941. A list of the fishes known from the Andaman Islands. Mem. Indian Mus., 13 (3): 331-403.

- , 1953. Check list of Philippine fishes. Res. Rep. U.S. Fish Wildl. Ser., 20: 1-977.

- , 1958. Marine fishes in Philippine rivers and lakes. Philipp. J. Sci., 87 (1): $65-88$.

Herre, A. W. C. T. \& G. S. Myers, 1937. A contribution to the ichthyology of the Malay Peninsula. Bull. Raffles Mus., 13: 5-75, pls. 1-7.

Hervey, G. F. \& J. HeMS, 1963. Freshwater tropical aquarium fishes: i-xiv, $1-432$, figs. $1-89$, pls. $1-8$, A-X (Spring books, London).

HorA, S. L., 1923a. Fauna of the Chilka Lake. Fish. Part V. Mem. Indian Mus., 5: 739-769, figs. 22-35.

-, 1923b. On a collection of fish from Siam. J. nat. Hist. Soc. Siam, 6 (2): $143-184$, pls. $10-12$.

-, 1924. Zoological results of a tour in the Far East. Fish of the Talé Sap, Peninsular Siam. (Part II). Mem. Asiat. Soc. Beng., 6: 479-501, figs. 4-10.

- 1929. An aid to the study of Hamilton Buchanan's "Gangetic Fishes". Mem. Indian Mus., 9 (4): 169192, 1 fig., pls. 13-23.

-, 1933. Buchanan's ichthyological manuscript entitled "Piscium Bengalae Inferioris Delineationes". J. Proc. Asiat. Soc. Beng., (N.S.) 27 (1931) (1): 123-135.

HoRA, S. L. \& K. K. NAIR, 1941. Notes on fishes in the Indian Museum XLI. New records of freshwater fish from Travancore. Rec. Indian Mus., 43: 387-393, figs. $1-4$.

Hubrecht, A. A. W., 1879. Catalogue des collections formées et laissées par M.- P. Bleeker....: i-iv, 1-71 (De Breuk \& Smits, Leiden).

INGER, R. F., 1953. A new fish from North Borneo. Genus Tetraodon. Fieldiana Zool., 34 (11): 149-152, fig. 27.

- 1955. Ecological notes on the fish fauna of a coastal drainage of North Borneo. Fieldiana Zool., 37: 4790 , figs. $10-13$.

INGER, R. F. \& P. K. CHIN, 1962. The fresh-water fishes of North Borneo. Fieldiana Zool., 45: 3-268, figs. $1-120$.

INNES, W. T., 1935. Exotic aquarium fishes, a work of general reference, edited by G. S. MYERS (19th ed.): 1-541, ca. 450 figs., 1 pl. (Innes Publ. Co., Philadelphia).

JOHNSEN, P., 1964. Notes on fishes along the river Kwae Noi in Western Thailand. Pt. 2. Nat. Hist. Bull. Siam Soc., 20: $257-263$.

JoRDAN, D. S. \& R. E. RichaRdson, 1909. Check-list of the species of fishes known from the Philippine Archipeiago. Publs Philipp. Bur. Sci., 1: 1-78.

Károli, J., 1882. Prodromus piscium Asiae Orientalis a domine Joanne Xantus annis $1868-70$ collectorum. Természetr. Füz., 5: 147-187.

KLAUSEWITZ, W., 1957a. Neue Süsswasserfische aus Thailand. Senckenberg. biol., 38 (3/4): 193-204, Abb. 1-5, Taf. 17-18.

-, 1957b. Tetraodon somphongsi n. sp., ein weiterer neuer Kugelfisch aus Thailand (Pisces, Tetraodontidae). Senckenberg. biol., 38 (3/4): 205-208, Abb. $1-2$.

-, 1957c. Eine neue Kugelfisch-Art aus Siam: Tetraodon somphongsi. Aquar.- u. Terrar.-Z., 10: 115-116, 2 figs.

KNER, R., 1867. Reise der Österreichischen Fregatte Novara um die Erde in den Jahren 1857, 1858, 1859 unter den Befehlen des Commodore B. von Wüllerstorf-Urbair. Zoologischer Theil. Erster Band. Fische, dritte Abtheilung: 273-433, Taf. XII-XVI (K.-K. Hofund Staatsdruckerei, Wien).

Koumans, F. P., 1947. Zoological notes from Port Dickson, II. A small collection of fishes from Malaya. Zoöl. Meded. Leiden, 27 (3-4): 309-311.

LadIGES, W., 1954. Tropische Fische - Tropical fish: 1-207, 284 figs., 43 pls. (G. Wenzel \& Sohn, Braunschweig).

LE Danols, Y., 1959. Etude ostéologique, myologique et systématique des poissons du sous-ordre des Orbiculates. Annls Inst. océanogr., Monaco, (N.S.) 36: 1-274, figs. 1-221.

,- 1961 . Catalogue des types de poissons orbiculates du Muséum National d'Histoire Naturelle II. Familles des Tetraodontidae, Lagocephalidae, Colomesidae, Diodontidae et Triodontidae. Bull. Mus. natn. Hist. nat. Paris, (2) 33 (5): 462-478.

-, 1962. Transitions morphologiques et ostéologiques entre les espèces du genre Dichotomycterus (Tetraodontidae). Bull. Soc. zool. Fr., 86: 694-700, figs. $1-11$.

LüLING, K. H., 1958. Zufallsbeobachtungen an Tetraodon somphongsi und Gyrinocheilus aymonieri (Tirant). Aquar.- u. Terrar.-Z., 11 (1): 11-15, Abb. 1-4.

McCulloch, A. R., 1922. Check list of the fish and fish-like animals of New South Wales. Part. iii. Aust. Zool., 2 (3): 86—130, pls. xxv-xliii.

Marion de Procé, 1822. Sur plusieurs espèces nouvelles de poissons et de crustacés observées par M. Marion de Procé, D. M. P., membre correspondant de la Société Philomatique. Bull. Soc. philom. Paris, 1822: $129-134$.

MeinKen, H., 1956. Mitteilungen der Fischbestimmungs- 
stelle des VDA. XXI. Tetraodon palembangensis Bleeker, 1852, der Palembang-Kugelfisch. Aquar.- u. Terrar.-Z., 9 (3): 61-63, 1 fig.

MENON, A. G. K., 1961a. On a collection of fish from Lake Chilka, Orissa. Rec. Indian Mus., 59: 41-69, fig. 1.

,$- 1961 \mathrm{~b}$. On a collection of fish from the Coromandel Coast of India including Pondicherry and Karaikkal areas. Rec. Indian Mus., 59 (4): 369-404.

Menon, A. G. K. \& G. M. Yazdani, 1963. Catalogue of type-specimens in the Zoological Survey of India. Part 2. Fishes. Rec. zool. Surv. India, 61: 91-190.

MerCKenS, P. J., 1958. Zoetwater-kogelvissen 1. Aquarium, Den Haag, 29 (3): 50-54, 8 figs.

- , 1959. Zoetwater-kogelvissen 3. Aquarium, Den Haag, 29 (8): 170-172, 2 figs.

MunRo, I. S. R., 1955. The marine and fresh water fishes of Ceylon: i-xvi, 1-351, figs. 1-19, pls. 1-56 (Dept. external affairs, Canberra).

,- 1958 . The fishes of the New Guinea Region. A check list of the fishes in New Guinea incorporating new records of species collected by the Fisheries Survey Vessel Fairwind during the years 1948 to 1950. Papua New Guin. agric. J., 10 (4): 97-369, fig. 1, maps $1-3$.

- , 1967. The fishes of New Guinea: i-xxxvii, 1-651, figs. $1-23$, col. pls. $1-6$, pls. $1-78$ (Dep. Agriculture, Stock and Fisheries, Port Moresby).

OGilby, J. D., 1886. Catalogue of the fishes of New South Wales, with their principle synonyms: $1-67$ (Th. Richards, Sydney).

OSTERMöLleR, W., 1957. Einige Beobachtungen über Tetraodon somphongsi. Aquar.- u. Terrar.-Z., 10 (11): 288-290, 1 fig.

Pellegrin, J. \& P. W. Fang, 1940. Poissons du Laos recueillis par MM. Delacour, Greenway, Ed. Blanc. Description d'un genre, de cinq espèces et d'une variété. Bull. Soc. zool. Fr., 65: 111-123, figs. 1-6.

Pellegrin, J. \& P. Chevey, 1940. Poissons nouveaux ou rares de Cochinchine. Descriptions de deux espèces et de deux variétés. Bull. Soc. zool. Fr., 65: 153-158, figs. 1-2.

Popta, C. M. L., 1905. Suite des descriptions préliminaires des nouvelles espèces de poissons recueillies au Bornéo Central par M. le Dr. A. W. Nieuwenhuis en 1898 et en 1900 . Notes Leyden Mus., 25 (4): 171-186.

,- 1906 . Résultats ichthyologiques des voyages scientifiques de Monsieur le Professeur Dr. A. W. Nieuwenhuis dans le centre de Bornéo (1898 et 1900). Notes Leyden Mus., 27: 1-304, pls. I-X.

Prashad, B. \& D. D. Mukerji, 1929. The fish of the Indawgyi Lake and the streams of the Myitkyina District (Upper Burma). Rec. Indian Mus., 31 (3): 161-224, pls. VII-X.

RanDow, H., 1934. Tetrodon cutcutia und Tetrodon fluviatilis Hamilton-Buchanan. Wschr. Aquar.- u. Terrarienk., 31: 561-563, Abb. 1.

REGAN, C. T., 1902. On the classification of the fishes of the suborder Plectognathi; with notes and descriptions of new species from specimens in the British Museum collection. Proc. zool. Soc. Lond., 1902 (II): 284-303, text-figs. 56-59, pls. XXIV-XXV.

Rofen, R. R., unpubl. Where are Pieter Bleeker's EastIndian fishes? (Undated and unpublished manuscript in the Institute of Taxonomic Zoology, Amsterdam).
Roxas, H. A. \& C. Martin, 1937. A check list of Philippine fishes. Tech. Bull. Commonw. Philipp. Dep. Agr. Commerce Manila, 6: 1-314.

RüPPELl, E., 1852. Verzeichniss der in dem Museum der Senckenbergischen Naturforschenden Gesellschaft aufgestellten Sammlungen. Vierte Abtheilung: Fische und deren Skelette: i-iv, $1-40$ (J. D. Sauerländer, Frankfurt am Main).

Sauvage, H. E., 1883. Sur une collection de poissons recueillie dans le Mé-Nam (Siam) par M. Harmand. Bull. Soc. philom. Paris, (7) 7: 150-155.

SCHNEIDER, H., 1964. Untersuchungen zur Schwimmsweise der Kugelfische. 1. Die Flossenmuskulatur des Flusskugelfisches (Tetraodon fluviatilis) in Vergleich zu der Schleie (Tinca tinca). Z. Morph. Okol. Tiere, 54: $414-435,15$ figs.

Seale, A., 1910. Fishes of Borneo, with descriptions of four new species. Philipp. J. Sci., 5 (4): 263-289, pls. $1-4$.

Shaw, G. E. \& E. O. Shebreare, 1938. The fishes of northern Bengal. J. R. Asiat. Soc. Beng., 3: 1-137, figs. $1-130$, pls. $1-6$.

Smith, H. M., 1945. The fresh-water fishes of Siam, or Thailand. Bull. U.S. natn. Mus., 188: i-xi, 1-622, figs. 1-107, pls. 1-9.

Sontirat, S., S. Monkolprasit \& P. Wongrat, 1971. Notes on Tetraodon Somphongsi, Klausewitz, 1957, a puffer fish from Thailand. Notes Fac. Fish. Kasetsart Univ., 6: 5-6.

SRIVAStaVA, G. J., 1968. Fishes of eastern Uttar Pradesh: i-xxii, 1-163, figs. 1-86 (Vishwavidyalaya Prakashan, Varanasi).

SteindaCHNER, F, 1870. Ichthyologische Notizen (X). Sber. Akad. Wiss. Wien, 60 (1): 623-642, Tab. 1-5.

STERBA, G., 1959. Süsswasserfische aus aller Welt. Teil 2: 357-688, Abb. $360-620$. Taf. $145-280$ (UraniaVerlag, Leipzig/Jena/Berlin).

Suvatri, C., 1936. Index to fishes of Siam: A-F, 1-226, 1 pl., 1 map (Bureau of Fisheries, Bangkok).

Swainson, W., 1839. The natural history of fishes, amphibians, \& reptiles, or monocardian animals. II: i-vi, 1-452, figs. 1-135 (Longman, Brown, Green \&c Longmans, London).

Tirant, G., 1885. Notes sur les poissons de la BasseCochinchine et du Cambodge. Excurs. Reconn., 9: 413-438; 10: 91-198. Id., réimprimé en 1929: Notes Stn marit. Cauda, 6: 43-163.

Tweedie, M. W. F., 1940. Additions to the collection of fishes in the Raffles Museum. Bull. Raffles Mus., 16: $68-82$.

- 1952. Notes on Malayan fresh-water fishes. Bull. Raffles Mus., 24: 63-95, figs. 1-4.

TYLER, J. C., 1963. A critique of Y. Le Danois' work on the classification of the fishes of the order Plectognathi. Copeia, 1963 (1): 203-206.

- , 1964. A diagnosis of the two species of South American puffer fishes (Tetraodontidae, Plectognathi) of the genus Colomesus. Proc. Acad. nat. Sci. Philad., 116 (3): 119-148, figs. 1-16.

Vaillant, L., 1893a. Contribution à l'étude de la faune ichthyologique de Bornéo. Nouv. Archs Mus. Hist. nat. Paris, (3) 5: 23-112, pls. 1-2.

,- 1893 b. Sur une collection de poissons recueillie par M. Chaper à Bornéo. Bull. Soc. zool. Fr., 18: 55-62.

,- 1902 . Résultats zoologiques de l'expédition scientifi- 
que Néerlandaise au Bornéo Central. Poissons. Notes Leyden Mus., 24 (1-3): 1-166, figs. $1-47$, pls. $1-2$.

Vinciguerra, D., 1883. Appunti ittiologici sulle collezioni del Museo Civico di Genova. V. Enumerazione di alcuni pesci raccolti a Minhla sull' Irrawaddi dal capitano cav. G. B. Comotto. Annali Mus. civ. Stor. nat. Genova, 18: $651-660$.

-, 1890. Viaggio di Leonardo Fea in Birmania e regioni vicine. XXIV. Pesci. Annali Mus. civ. Stor. nat. Genova, (2a) 9: 129-367, tav. VII-XI.

-, 1926. Catalogo dei pesci raccolti a Borneo dai Sigg. Marchese G. Doria e Dott. O. Beccari negli anni 1865-67. Annali Mus. civ. Stor. nat. Giacomo Doria, (3a) 10: 532-628, tav. I.

VLUGT, P. J. VAN DER, 1968. Carinotetraodon somphongsi. Aquarium, Den Haag, 38 (10): 218-224, 7 figs.

Volz, W., 1903. Fische von Sumatra (Reise von Dr. Walter Volz). Zool. Jb. (Syst.), 19 (4): 347-420, 1 Abb., Taf. 25-26.

-, 1904. Fische von Sumatra gesammelt von Herrn G. Schneider. Revue suisse zool., 12 (2): $451-493$.

,- 1906 . Catalogue of the fishes of Sumatra. Natuurk. Tijdschr. Ned.-Indië, 66 (1-2): 35-250.

Waite, E. R., 1904. A synopsis of the fishes of New South Wales. Mem. N. S. W. Nat. Club, 2: 3-59, i-iv.

WEBER, M., 1894. Die Süsswasser-Fische des Indischen
Archipels, nebst Bemerkungen über den Ursprung der Fauna von Celebes. In: M. Weber ed., Zoologische Ergebnisse einer Reise in Niederländisch Ost-Indien. III: 405-476 (Brill, Leiden).

-, 1895. Fische von Ambon, Java, Thursday Island, dem Burnett-Fluss und von der Südküste von Neu-Guinea. Denkschr. med.-naturw. Ges. Jena, 8: 259-276, 1 Textfig.

-, 1911. Die Fische der Aru- und Kei-Inseln. Ein Beitrag zur Zoogeographie dieser Inseln. Abh. Senckenb. naturforsch. Ges., 34: $1-49$, figs. $1-11$, pls. 1-2.

-, 1913. Süsswasserfische aus Niederländisch Süd- und Nord-Neu-Guinea. Nova Guinea (Zool.), 9 (4): 513613 , figs. $1-36$, pls. $12-14$.

Weber, M. \& L. F. de Benufort, 1912. Fische. In: A. MAASS ed., Durch Zentral-Sumatra. II: $1-20$ (C. Marschner, Berlin).

Whitehead, P. J. P., M. Boeseman \& A. C. Wheeler, 1966. The types of Bleeker's Indo-Pacific elopoid and clupeoid fishes. Zool. Verh. Leiden, 84: 1-159, pls. $1-19$.

Whitley, G. P., 1957. List of type-specimens of recent fishes in the Australian Museum, Sydney: i-iii, $1-40$ (mimeograph, Australian Museum, Sydney).

Willem, V., 1947. Contributions à l'étude des organes respiratoires chez les Téléostéens Plectognathes (1). 5e Partie: Tétrodontes et Diodon. Bull. Mus. r. Hist. nat. Belg., 23 (17): 1-17, figs. 1-10.

\section{INDEX TO THE TAXONOMIC PART}

Main references are printed in bold type

bergii, Tetraodon

$103,109,111$

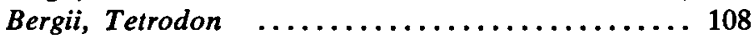

biocellatus, Tetraodon ................ 119-120

borneensis, Tetraodon ............... 94, 97, 99

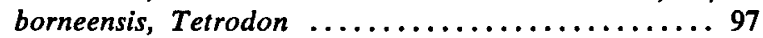

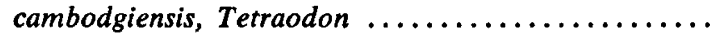

..........103, 104, 108, 109, 110; figs. 13, 18-20

cambodgiensis, Tetrodon ................ 108

caria, Tetraodon ....................... 93-94

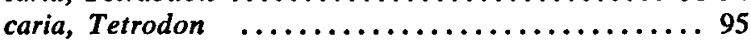

caria, Monotreta ..................94, 97

chlupatyi, Carinotetraodon .......... 93, 94, 97, 99

chlupatyi, Tetraodon .................. 94

cutcutia-group $\ldots \ldots \ldots \ldots \ldots .99,93-95,100,102,114$

cutcutia, Arothron? .................... 95

cutcutia, Leiodon $. . \ldots \ldots \ldots \ldots \ldots \ldots \ldots . \ldots 5$

cutcutia, Leiosomus ................... 95

cutcutia, Monotrète $\quad . \ldots \ldots \ldots \ldots \ldots \ldots \ldots . \ldots 9$

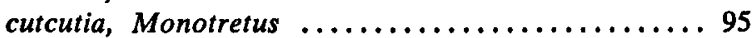

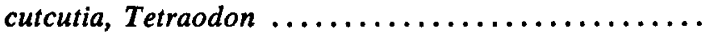

$\ldots \ldots \ldots .92,93,94,95-97,100,101,112$; figs. $3-5$

cutcutia, Tetraödon .................. 95

cutcutia, Tetrodon ..................... 95

cutcutia, cutcutia, Monotreta ................ 108

cutcutia palembangensis, Monotreta ....... 102, 105

dorsovittatus, Arothron ................ 119, 127

dumerili, Chelonodon ................ 94, 97

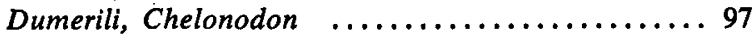

erijthrotaenia, Tetraödon ................. 115

erythrotaenia-group .......992,93, 102, 114-115, 120

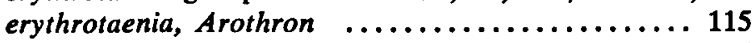

erythrotaenia, Crayracion .............114, 115

erythrotaenia, Monotretus ................... 115

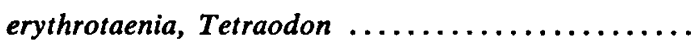

$\ldots \ldots \ldots \ldots \ldots 92,93,114,115-117,120$; figs. $24-25$

erythrotaenia, Tetraödon ................ 115

erythrotaenia, Tetrodon $\ldots \ldots \ldots \ldots \ldots \ldots \ldots \ldots \ldots \ldots \ldots$

fangi, Tetraodon ................ 92, 93,

$95,102,103,104,107-108,112-114$; figs. $13,21-23$

fangi, Tetrodon .................... 112

fluviatilis-group .......92, 93, 102, 104, 112, 117-120

fluviatilis, Chelanodon ................... 127

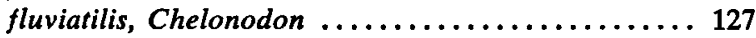

fluviatilis, Crayracion ............ 120, 124, 127

fluviatilis, Dichotomycter ............ 121, 124

fluviatilis, Dichotomyctère ............... 123

fluviatilis, Dichotomycterus ......... 124, 127, 129

fluviatilis, Tetraodon ........... 108, 117, 118,

$119,120-121,123,124,127,130,134,135$; figs. $32-37$

fluviatilis, Tetraödon $\ldots \ldots \ldots \ldots \ldots \ldots \ldots \ldots \ldots \ldots$

fluviatilis, Tetrodon .......... 120-121, 124, 127, 135

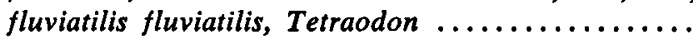

........ 92, 93, 117, 119, 127-130; figs. $32-34$

fluviatilis var. A, Tetrodon ............ 119, 127

fluviatilis var. B, Tetrodon ................. 127

fluviatilis var. ocellata, Crayracion .... 119, 132, 134

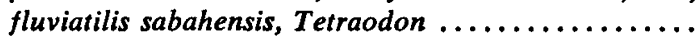

........... 92, 93,117, 120, 130-132; figs. 35-37

gernaerti, Epipedorhynchus ................. 115

Gernaerti, Epipedorhynchus ............. 114-115

gularis, Monotreta ................. 94, 95

gularis, Tetraodon ..................... 93-94

gularis, Tetrodon .................... 95

hilgendorfii, Tetraodon .... 103, 104, 109, 111; fig. 13

Hilgendorfii, Tetrodon ................... 108

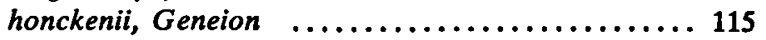


javanicus, Dichotomyctère ................. 124

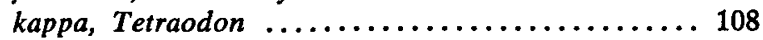

kretamensis, Tetraodon ............. 92, 93,

$114,117,118,120,121-123,127,130$, figs. $26-28$ leiurus-group .......... 92, 93, 102-104, 114; fig. 13 leiurus, Arothron ................. 107, 108

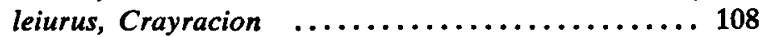

leiurus, Tetraödon ................... 108

leiurus, Tetraodon ......... 92, 93, 94, 97, 102, 103,

$104,105,107-108,108-112,121,124$; figs. $13,16-20$

leiurus, Tetrodon ................ 108, 109, 112 leiurus brevirostris, Tetraodon .. 95, 103, 109, 112, 113 lineatus, Tetraodon ................... 92

lineatus, Tetraödon ................... 104

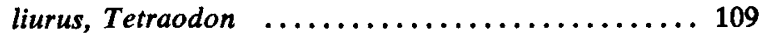

liurus, Tetrodon .................... 108

lorteti, Tetraodon .......92, 93, 94, 97-101; figs. 6-9

lorteti, Tetrodon ................... 97

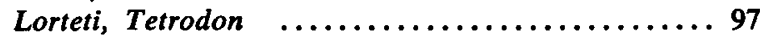

marmoratus, Leiodon .................. 94

marmoratus, Leiosomus ................ 94, 95

modestus, Chonerinus .................. 92

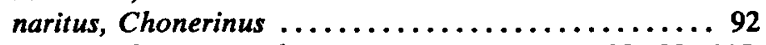

nigroviridis, Tetraodon $\ldots \ldots \ldots \ldots \ldots \ldots 92,93,115$,

$117,118,119,120,121,123-127,134$; figs. 29-31

nigroviridis, Tetrodon $\ldots \ldots \ldots \ldots \ldots \ldots \ldots \ldots \ldots 123$

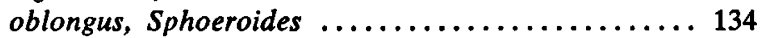

ocellaris, Tetraodon ........... 103, 112, 113, 134

ocellatus, Sphoeroides $\ldots \ldots \ldots \ldots \ldots \ldots \ldots \ldots . \ldots 92$

ocellatus, Tetraodon ............... 119-120, 134

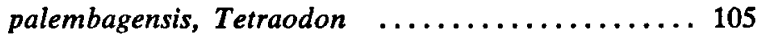

palembangensis, Arothron .............. 102, 105

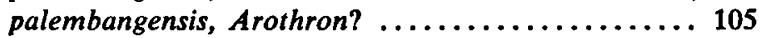

palembangensis, Crayracion .............. 105

palembangensis, Tetraodon ....... 92, 93, 94, 97, 102,

104-107, 108, 109, 111, 112, 119, 132, 134; figs. 14-15

palembangensis, Tetraödon .............. 104-105 palembangensis, Tetrodon ........... 105, 108, 132

palembangensis Variété, Tetrodon ............. 105

patoca, Chelonodon .................... 92

patoca, Monotreta ..................... 92

patoca, Tetraodon ............ 92, 103, 112, 134

pelambangensis, Tetraodon ................ 105

pinguis, Tetraodon ..............102, 105, 106

pinguis, Tetrodon ..................... 108

pleurogramma, Sphoeroides .............. 114

potamophilus, Arothron ................... 123

potamophilus, Tetraodon ............. 118, 124

potamophilus, Tetraödon ................. 123

rangoonensis, Dichotomycterus ....... 124, 127, 129

rangoonensis dorsovittatus, Dichotomycterus .. 119, 127

rangoonensis, Tetraodon ................. 119

reticulatus, Tetraödon .................... 104

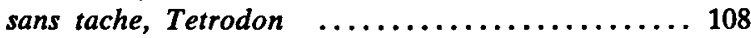

semimaculatus, Arothron ............... 119,120

simulans, Arothron ................. 123-124

simulans, Tetraodon ............ 118, 124, 125

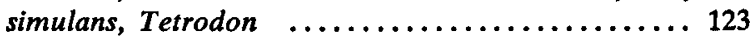

somphongsi, Carinotetraodon .............. 97

somphongsi, Tetraodon .............94, 97

steindachneri, Tetraodon ................ 92,

$93,112,114,117,118,120,132-134$; figs. $38-40$ tiranti, Monotreta .............. 94, 97, 105

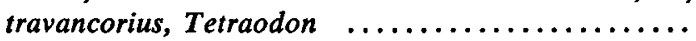

$\ldots \ldots \ldots .92,93,94,100,101-102,114$; figs. $10-12$ viridipunctatus, Tetraodon ............ 119, 127 waandersii-group $\ldots \ldots \ldots \ldots \ldots \ldots . . \ldots 2,93,134,135$ Waandersii, Arothron $\ldots \ldots \ldots \ldots \ldots \ldots \ldots$ 134-135

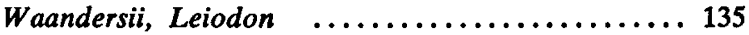

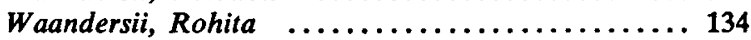
waandersii, Tetraodon ..... 92, 93, 134-135; figs. $41-42$

Waandersii, Tetraödon $\ldots \ldots \ldots \ldots \ldots \ldots \ldots . \ldots 134$

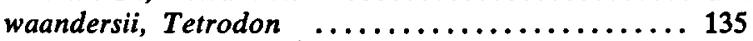

werneri, Tetraodon ............... 94, 97

Received: 9 October 1974 